DANIELI TELES LIVIÉRI COSTA

\title{
A OFICINA PEDAGÓGICA NA EDUCAÇÃO EM SAÚDE PARA PROMOÇÃO DO DESENVOLVIMENTO DE LACTENTES
}

São Paulo

2016 


\title{
DANIELI TELES LIVIÉRI COSTA
}

\section{A OFICINA PEDAGÓGICA NA EDUCAÇÃO EM SAÚDE PARA PROMOÇÃO DO DESENVOLVIMENTO DE LACTENTES}

Versão corrigida da Dissertação apresentada ao Programa de Pós-Graduação em Enfermagem da Escola de Enfermagem da Universidade de São Paulo para obtenção do título de Mestra em Ciências.

Área de concentração: Cuidados em Saúde.

Orientadora: Prof. ${ }^{a}$ Dr. ${ }^{a}$ Maria de La Ó Ramallo Veríssimo

\begin{abstract}
VERSÃO CORRIGIDA
A versão original encontra-se disponível na Biblioteca da Escola de Enfermagem da Universidade de São Paulo e na Biblioteca Digital de Teses e Dissertações da Universidade de São Paulo.
\end{abstract}

São Paulo

2016 
AUTORIZO A REPRODUÇÃO E DIVULGAÇÃO TOTAL OU PARCIAL DESTE TRABALHO, POR QUALQUER MEIO CONVENCIONAL OU ELETRÔNICO, PARA FINS DE ESTUDO E PESQUISA, DESDE QUE CITADA A FONTE.

Assinatura:

Data:

Catalogação na Publicação (CIP)

Biblioteca "Wanda de Aguiar Horta"

Escola de Enfermagem da Universidade de São Paulo

Costa, Danieli Teles Liviéri

A oficina pedagógica na educação em saúde para promoção do desenvolvimento de lactentes / Danieli Teles Liviéri Costa. São Paulo, 2016.

$124 \mathrm{p}$.

Dissertação (Mestrado) - Escola de Enfermagem da Universidade de São Paulo.

Orientadora: Prof. - Dr. ${ }^{\text {a }}$ Maria de La Ó Ramallo Veríssimo Área de concentração: Cuidados em Saúde

1. Educação em saúde. 2. Lactentes. 3. Desenvolvimento infantil. 4. Cuidados de enfermagem. 5. Brincadeiras. 6. Enfermagem. I. Título. 
Nome: Danieli Teles Liviéri Costa

Título: A oficina pedagógica na educação em saúde para promoção do desenvolvimento de lactentes.

Dissertação apresentada ao Programa de Pós-Graduação em Enfermagem da Escola de Enfermagem da Universidade de São Paulo para obtenção do título de Mestra em Ciências.

Aprovado em:

\section{Banca Examinadora}

Prof. Dr. Instituição:

Julgamento: Assinatura:

Prof. Dr. Instituição:

Julgamento: Assinatura:

Prof. Dr. Instituição:

Julgamento: Assinatura: 
Dedica este trabalha...

Aas meus pais, Sérgia e Celia, meus maiares exemplas de dedicaçãa, farça e caragem! A quem deva a vida e tuda que sau...

Aa meu marida Ruben, pela apaia incandicianal.

Aas meus queridas auás, Jasé e Neide, Antânia e Maria Jasé.

A tada minha familia e amigas, que me apaiaram durante tada essa trajetória.

A tadas que tarnaram este sanka passúuel. 


\section{AGRADECIMENTOS}

Primeiramente, agradeço a Deus por ter me abençoado durante toda trajetória. Por ter me dado forças para seguir em frente, por ter iluminado meu caminho e permitido tantas realizações!

Aos meus pais, Sérgio e Celia, por terem sonhado este sonho junto comigo, por terem me acompanhado tantas vezes nas viagens, por ficarem esperando do lado de fora pelo término das aulas, por me sustentarem em cada etapa, e nunca me deixarem desistir. Sem vocês nada seria possível, obrigada por tudo!

Ao meu querido e amado marido Ruben, por todo seu apoio diário, companheirismo e paciência inesgotável. Por ter feito parte dessa história me amparando e dando forças com tanto carinho e amor. Por ter cuidado tão bem de mim e pela compreensão diante de tantas ausências.

Aos meus avós, por todo apoio, pelas orações para que tudo ocorresse bem durante as viagens, por acreditarem em mim e pelo incentivo.

A minha Tia Denise e Tio Robinson, que me levou tantas vezes para as aulas. Muito obrigada por todo apoio!

A toda minha querida família, pelo suporte e pela torcida de sempre. Vocês são a minha vida!

A minha querida grande amiga-irmã, Silvana Aparecida Sanavio, que voluntariamente participou desta pesquisa, contribuindo para a realização deste sonho. E por toda sua amizade. 
A Secretaria de Saúde de Boituva/SP, em especial ao diretor de Divisão e Planejamento, Samoel Mariano, por ter permitido inúmeras dispensas do trabalho que exerço no município, pelo infinito apoio e por sua amizade.

À querida Prof. ${ }^{\text {a }}$ Dr. ${ }^{\text {a }}$ Maria de La Ó Ramallo Veríssimo, mais que uma orientadora. Por ter me recebido com tanto carinho e me conduzido durante esse processo com muita sabedoria. Obrigada por tantos conhecimentos compartilhados e por tornar possível a realização deste sonho tão especial para mim.

A todos os membros do Grupo de Pesquisa "Cuidado em Saúde e Promoção do Desenvolvimento Infantil" da Escola de Enfermagem da USP, pelos grandes conhecimentos e experiências compartilhadas, e por terem construído este trabalho junto comigo. E pela amizade construída.

A todos os funcionários da Escola de Enfermagem da USP, pela convivência, apoio e respeito.

À querida Prof. ${ }^{\text {a }}$ Dr. ${ }^{\text {a }}$ Aurea Tamami Minagawa Toriyama, por ter se tornado uma amiga, por compartilhar seus conhecimentos e pelo apoio sempre.

À Prof. ${ }^{a}$ Dr. ${ }^{-}$Cecília Helena de Siqueira Sigaud, por seus ensinamentos valiosos e por todo seu carinho.

À Prof. ${ }^{a}$ Dr. ․ㅡ Luciana de Lione Melo, um grande exemplo, por tanto ter contribuído para o meu conhecimento durante essa trajetória, em especial para inserção no mestrado. 
A todos os docentes e colegas com que tive contato durante essa trajetória.

A toda querida equipe da Unidade Estratégia Saúde da Família Aparecidinha de Sorocaba, por terem me recebido com tanta ternura e pelo apoio incondicional.

À Secretaria de Saúde de Sorocaba, que prontamente autorizou a realização da pesquisa.

A todas as famílias que participaram deste estudo contribuindo para o meu crescimento profissional e pessoal.

A todos, que direta ou indiretamente tornaram este sonho realidade! 
"Ninguém nasce feito, é experimentando-nos no mundo que nós nos fazemos".

Paulo Freire 
Costa DTL. A oficina pedagógica na educação em saúde para promoção do desenvolvimento de lactentes [dissertação]. São Paulo: Escola de Enfermagem, Universidade de São Paulo; 2016.

\section{RESUMO}

Introdução: A Oficina Pedagógica é potencialmente útil na educação em saúde, pois visa ao diálogo, troca de saberes e relação horizontal entre profissionais e usuários. Objetivo Geral: Avaliar o efeito de uma atividade educativa sobre os conhecimentos e práticas dos familiares de lactentes, relativos à promoção do desenvolvimento infantil por meio do brincar. Objetivos específicos: Avaliar a qualidade de estimulação no ambiente doméstico, antes e após a realização de uma ação educativa; planejar e realizar uma ação educativa, na modalidade de Oficina Pedagógica, sobre desenvolvimento infantil e brincadeira; descrever as facilidades e dificuldades na execução da ação educativa, bem como a opinião das participantes sobre a atividade educativa realizada. Método: estudo quantitativo, com delineamento experimental, na cidade de Sorocaba, interior de São Paulo. A população constitui-se de cuidadores de crianças com idade entre 1 e 24 meses, cadastradas numa Unidade Estratégia Saúde da Família. Para a coleta de dados, foi aplicado o Inventário Home Observation for Measurement of the Environment Scale, versão para o grupo etário de 0 a 3 anos (IT-HOME), antes e depois da ação educativa; foi também aplicado um questionário de avaliação da oficina e realizada uma discussão grupal ao seu final. O Grupo Experimental (GE) participou de uma Oficina Pedagógica delineada segundo os fundamentos da educação popular em saúde, sobre a temática do desenvolvimento infantil e a brincadeira. A análise dos dados compreendeu análises descritivas e o teste estatístico para medidas repetidas modelo ANOVA ("Analysis of Variance"), para comparar o GE e o grupo controle (GC) após a ação educativa. Pesquisa aprovada pelo Comitê de Ética em Pesquisa da Escola de 
Enfermagem da USP (parecer 952.23 e CAAE 38202814.2.0000.5392), conforme as diretrizes da Resolução 466 de 2012 do Conselho Nacional de Saúde. Resultados: antes da ação educativa, 30 crianças foram avaliadas, sendo 23,3\% classificadas em baixo risco para o desenvolvimento, $56,7 \%$ em médio e 20,0\% em alto risco; crianças mais jovens tiveram classificação de risco maior. Foram realizadas duas Oficinas Pedagógicas, com dois encontros cada, com envolvimento de onze famílias. A oficina foi avaliada como facilitadora do aprendizado devido à troca de saberes, experiências e reflexões sobre 0 desenvolvimento infantil e ações apropriadas para sua promoção. A reaplicação do IT-HOME alcançou nove crianças do GE e oito do GC. As classificações de risco melhoraram para ambos os grupos, mantendo-se maior risco para as crianças mais jovens; não houve diferença entre o GE e GC no IT-HOME, embora as cuidadoras do GE relatassem mais mudanças em suas práticas, devido aos conhecimentos adquiridos. Conclusões e considerações: A ação educativa participativa foi bem aceita e promoveu ações favoráveis ao desenvolvimento. A ausência de diferença entre os grupos na aplicação do IT-HOME pode dever-se às perdas, sendo recomendáveis outros estudos com maiores números de crianças. A atuação dos enfermeiros segundo os fundamentos da educação popular pode favorecer 0 acesso ao conhecimento sobre a estimulação do desenvolvimento infantil no ambiente doméstico, desde o pré-natal, considerando o maior risco de baixa estimulação para as crianças mais jovens.

PALAVRAS-CHAVE: Educação em saúde. Enfermagem de atenção primária. Cuidado do lactente. Desenvolvimento infantil. Brincadeiras. 
Costa DTL. The Pedagogical Workshops on health education to promote the development of infants [dissertation]. São Paulo (SP), Brasil: Escola de Enfermagem, Universidade de São Paulo; 2016.

\section{ABSTRACT}

Introduction: The Pedagogical Workshop is potentially useful in health education, since it aims to the dialogue, exchange of knowledge and horizontal relationship between professionals and users. General Aim: To evaluate the effect of an educational activity on the knowledge and practices of family members of infants, promoting child development through playing activities. Specific Aims: To evaluate the quality of stimulation at home, before and after carrying out an educational activity; to plan and to conduct an educational activity, in the form of a Pedagogical Workshops on child development and playing; describe the advantages and difficulties in the implementation of educational activities, as well as the opinion of the participants of the educational activity carried out. Method: quantitative study, with experimental design, in the city of Sorocaba, countryside of São Paulo state. The population is made up of children's caregivers, aged 0 to 24 months, registered in the Family Health Strategy Unit. To collect data, was applied the Inventory Home Observation for Measurement of the Environment Scale, version for the age group 1-3 years (IT-HOME), before and after the educational activity; It was also applied a questionnaire to evaluate the workshop and held a group discussion at the end. The experimental group (EG) attended a Pedagogical Workshop outlined under the foundations of a health education program on the subject of child development and play. Data analysis comprised descriptive analysis and statistical test for repeated measures ANOVA model ("Analysis of Variance"), to compare the EG and the control group (CG) after the educational activity. This research was approved by USP School of Nursing's Ethics Research Committee (opinion 952.23 and CAAE 38202814.2.0000.5392), and followed the guidelines of Resolution 466 of 2012 of the National Health Council. 
Results: before the educational activity, 30 children were evaluated, with $23.3 \%$ classified as low risk for the development, $56.7 \%$ on average and $20.0 \%$ in high-risk; younger children had a higher risk classification. Two Pedagogical Workshops were held with two meetings each, involving eleven families. The workshop was evaluated as a facilitator of learning due to the exchange of knowledge, experiences, and reflections on child development and appropriate actions for its promotion. The re-application of IT-HOME reached nine children of $E G$ and eight $C G$. The risk ratings have improved for both groups and remaining as higher risk for younger children; there was no difference between the EG and $C G$ in the ITHOME, although the EG caregivers reported more changes in their practices due to the acquired knowledge. Conclusions and considerations: The participatory educational action was well accepted and promoted favorable actions to development. The lack of difference between the groups in the IT-HOME application might be due to the losses, being recommended further studies with a larger number of children. The role of nurses, according to the principles of popular education can facilitate the access to knowledge on the stimulation of child development at home, since the prenatal, considering the increased risk of low stimulation for younger children.

KEYWORDS: Health education. Primary care nursing. Infant care. Child development. Play and playthings. 


\section{LISTA DE ILUSTRAÇÕES}

Quadro 1 - $\quad$ A importância do tempo: as intervenções mais 32 importantes para a promoção do desenvolvimento no período pré-escolar, segundo os domínios do desenvolvimento e a idade da criança.

Esquema 1 - Etapas da Coleta de Dados.

Figura 1 - $\quad$ Modelo do convite entregue aos cuidadores para participação na Oficina Pedagógica.

Figura 2 - Formato de entrega do convite para 47 participação na Oficina Pedagógica.

Quadro 2 - Síntese das observações realizadas pelo 62 entrevistador e comentários das cuidadoras.

Figura 3 - $\quad$ Espaço para recreação montado na ESF 66 Aparecidinha.

Figura 4- $\quad$ Cartaz produzido na Oficina Pedagógica I, 68 segundo encontro.

Figura 5 - $\quad$ Cartaz produzido na Oficina Pedagógica II, 69 segundo encontro.

Quadro 3 - Síntese das observações realizadas pelo 79 entrevistador e comentários das cuidadoras. 


\section{LISTA DE TABELAS}

Tabela 1 - Distribuição dos artigos sobre o brincar com a

criança no contexto familiar encontrados e selecionados, segundo as Bases de Dados.

Tabela 2 - IT-HOME: escore bruto das subescalas e escore total.

Tabela 3 - Caracterização do cuidador primário da criança segundo faixa etária, escolaridade e realização de atividade remunerada.

Tabela 4 - Caracterização da criança segundo sexo, faixa etária e frequência em creche.

Tabela 5 - Classificação econômica de acordo com o 58 Critério ABEP, 2014.

Tabela 6 - Caracterização do ambiente doméstico por meio do Inventário IT- HOME.

58

Tabela 7 - Caracterização do ambiente doméstico por meio 59 do Inventário IT- HOME nas respectivas subescalas.

Tabela 8 - Medidas de tendência central dos escores de cada subescala do IT-HOME e pontuações mínimas e máximas possíveis.

Tabela 9 - Relação idade da criança $X$ estimulação do desenvolvimento por parte do cuidador primário.

Tabela 10 - Questionário de Avaliação das Oficinas Pedagógicas - Caracterização das participantes e da criança.

Tabela 11 - Avaliação das Oficinas Pedagógicas pelas 72 participantes.

Tabela 12 - Caracterização das cuidadoras dos GE e GC segundo faixa etária, escolaridade e realização de atividade remunerada. 
Tabela 13 - Classificação econômica de acordo com o 75 Critério ABEP, 2014.

Tabela 14 - Caracterização das crianças do GE e do GC 76 segundo sexo, faixa etária e frequência em creche.

Tabela 15 - Caracterização do ambiente doméstico por meio 76 do Inventário IT- HOME.

Tabela 16 - Interpretação dos dados pelo modelo ANOVA Medidas Repetidas, considerando média, DP, mediana e valor-p para coleta e interação. 


\section{SUMÁRIO}

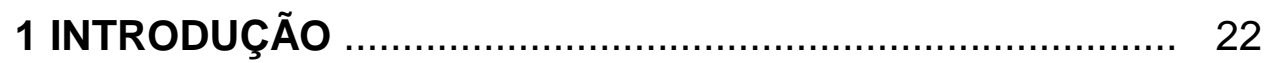

1.1 A EDUCAÇÃO EM SAÚDE E A ESTRATÉGIA DE OFICINA PEDAGÓGICA ................................................. 22

1.2 A ESCOLHA DO TEMA PARA A OFICINA PEDAGÓGICA ......................................................................... 25

1.2.1 Promovendo o desenvolvimento infantil: o brincar no contexto familiar ............................................................ 26

1.3 A ESCOLHA DA FAIXA ETÁRIA DAS CRIANÇAS ......... 30

1.4 JUSTIFICATIVA DO ESTUDO ........................................ 33

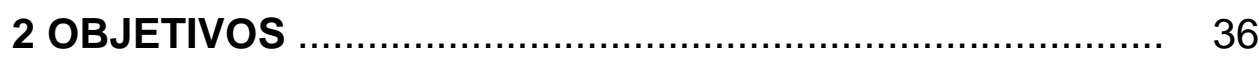

2.1 OBJETIVO GERAL …................................................... 36

2.2 OBJETIVOS ESPECÍFICOS ......................................... 36

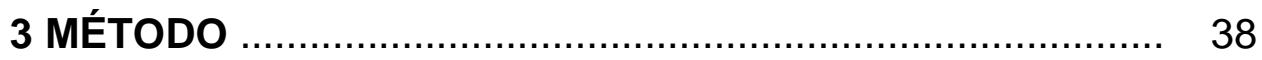

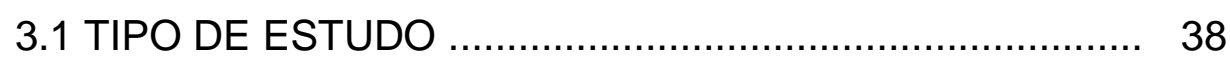

3.2 CENÁRIO DO ESTUDO …............................................ 39

3.3 POPULAÇÃO DO ESTUDO ............................................ 40

3.4 COLETA DE DADOS …............................................. 41

3.4.1 Primeira etapa ................................................. 41

3.4.1.1 Estudo piloto ............................................ 47

3.4.2 Segunda etapa ........................................... 48

3.4.3 Terceira etapa ................................................. 51

3.5 ANÁLISE DOS DADOS …............................................. 52

3.5.1 Primeira etapa …............................................ 52

3.5.2 Segunda etapa ............................................. 52

3.5.3 Terceira etapa ................................................ 52

3.6 CONSIDERAÇÕES ÉTICAS ........................................ 53

4 RESULTADOS ……............................................. 55

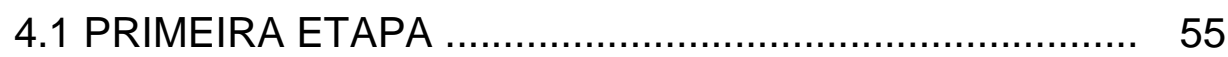

4.1.1 Caracterização dos cuidadores ........................... 55

4.1.2 Caracterização das crianças ................................ 56

4.1.3 Classificação Econômica ..................................... 57

4.1.4 Caracterização do ambiente domiciliar pelo

Inventário HOME 
4.2 SEGUNDA ETAPA …………............................... 65

4.3 TERCEIRA ETAPA …………………………......... 74

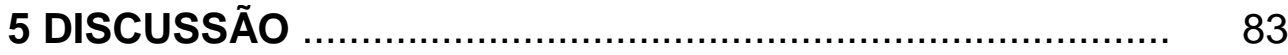

6 CONSIDERAÇÕES FINAIS …………………............... 93

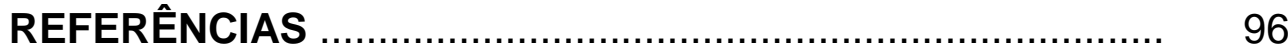

Apêndice A - Termo de Consentimento Livre e Esclarecido .... 101

Apêndice B - Descrição das Atividades da Oficina Pedagógica 103

Apêndice C - Questionário de Avaliação da Oficina

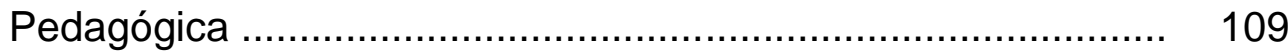

Anexo 1 - Folha de Registro HOME - 0 a 3 anos .................... 112

Anexo 2 - Critério de Classificação Econômica Brasil .............. 116

Anexo 3 - Aprovação do Comitê de Ética em Pesquisa da

EEUSP

Anexo 4 - Aprovação da Secretaria da Saúde do Município de Sorocaba/SP 


\section{APRESENTAÇÃO}

Durante minha trajetória profissional, pude vivenciar e refletir sobre os aspectos relativos à promoção do desenvolvimento infantil. Há cinco anos atuo como enfermeira na Atenção Primária em Saúde de um município do interior de São Paulo, trabalhando diretamente com o acompanhamento do crescimento e desenvolvimento da criança.

A Unidade de Puericultura, local em que atuo, está locada atualmente dentro do Centro de Referência em Saúde da Mulher, sendo responsável pelo atendimento em saúde a crianças de risco e com vulnerabilidade.

São atendidas crianças em situação de risco social, vítimas de violência doméstica, como a física, psicológica e sexual, crianças com doença crônica grave, asma, desnutridos ou com baixo peso, obesidade ou sobrepeso, síndromes genéticas e cardiopatias congênitas, além da triagem de todos os recém-nascidos do município por meio da primeira consulta do bebê.

O acompanhamento do crescimento e desenvolvimento da criança é realizado por meio de consultas médicas e de enfermagem. As ações de promoção da saúde e prevenção de agravos são desenvolvidas nos âmbitos individual e grupal. As ações individuais ocorrem durante as consultas e as ações em grupo acontecem na sala de espera pelo atendimento ou em reuniões previamente programadas.

Os profissionais que atuam com os grupos educativos são, além do enfermeiro, pediatra, psicóloga, fisioterapeuta, nutricionista e assistente social, envolvendo atividades com gestantes e família das crianças.

O enfermeiro estende ainda o seu atendimento para as creches e abrigo, único do município, no tocante às orientações de cuidado à saúde da criança em ambientes coletivos. 
$\mathrm{Na}$ recepção da Unidade, está disposto um espaço físico, composto por mesa e cadeiras infantis e brinquedos para que, durante o período de espera pelo atendimento, as crianças possam brincar.

Durante a jornada de trabalho, percebo que os responsáveis pelas crianças pouco interagem nesse momento de brincar. À criança, é permitido que fique naquele espaço brincando; porém os responsáveis não se envolvem com as atividades.

Nas consultas de enfermagem, quando esses responsáveis são questionados sobre a promoção do desenvolvimento infantil por meio da brincadeira, fica nítida a atribuição do brincar a um momento da criança e, quando essa criança é menor de um ano, menos importância o adulto confere ao brincar.

Tal observação motivou a necessidade de despertar na família a importância sobre a brincadeira visando à promoção do desenvolvimento infantil, visto que a família tem papel fundamental no processo de cuidado da criança, influenciando diretamente o seu desenvolvimento e impactando na qualidade do mesmo.

Além das atividades desenvolvidas na Unidade, estou inserida no Comitê de Mortalidade Materno-Infantil e Fetal desde 2011 e no grupo condutor para implantação da Rede Cegonha no município desde 2012, em que os aspectos do cuidado e da educação em saúde para promover o desenvolvimento integral e saudável da criança ficam cada vez mais em evidência.

Concomitante a isso, a minha inserção no grupo de pesquisa "Cuidado em Saúde e Promoção do Desenvolvimento Infantil" da Escola de Enfermagem da Universidade de São Paulo (USP) em 2011, corroborou intensamente para as reflexões acerca do desenvolvimento infantil, em especial para as ações de promoção exercidas pela família, em associação à lacuna vivenciada na prática diária de assistência. 
Diante dessa realidade, essa pesquisa surgiu pela necessidade em incentivar às famílias nas ações de promoção do desenvolvimento da criança, tendo a brincadeira como elemento fundamental desse processo e o ambiente doméstico como o local que permeia essas relações.

Para concretização dessa proposta, a ação educativa foi escolhida, na perspectiva de que o incentivo à estimulação possa ser oriundo de ações de baixo custo, acessíveis aos profissionais e serviços de saúde. 
INTRODUÇÃO 


\title{
1 INTRODUÇÃO
}

\subsection{A EDUCAÇÃO EM SAÚdE E A ESTRATÉGIA DE OFICINA PEDAGÓGICA}

O Ministério da Saúde define educação em saúde como:

\begin{abstract}
"Processo educativo de construção de conhecimentos em saúde que visa à apropriação temática pela população. Conjunto de práticas do setor que contribui para aumentar a autonomia das pessoas no seu cuidado e no debate com os profissionais e os gestores a fim de alcançar uma atenção de saúde de acordo com suas necessidades" (Brasil, 2006).
\end{abstract}

As práticas relacionadas à educação em saúde envolvem três segmentos de atores prioritários: profissionais da saúde que valorizem a prevenção e a promoção tanto quanto as práticas curativas, gestores que apoiem esses profissionais, e a população, sendo que esta deve ser capaz de construir seus conhecimentos e aumentar sua autonomia nos cuidados tanto individuais quanto coletivos (Falkenberg et al., 2014).

A educação em saúde visa à autonomia das pessoas em relação aos processos de saúde e doença e de suas condições de vida, que são possíveis geradores de doenças, porém, ainda é vista como a transmissão de conhecimentos (Oliveira, Oliveira, 2006).

Uma das concepções mais generalizadas sobre educação em saúde é aquela cujas atividades se desenvolvem mediante situações formais de ensino-aprendizagem, caracterizadas pelo didatismo e pela assimetria expressa na ação do profissional de saúde, em que este se coloca na posição de "educador", enquanto que os usuários dos serviços se situam na condição de "educandos" (Flores, 2007).

O didatismo ocorre quando as atividades desenvolvidas não consideram as condições de risco da comunidade nem suas reais necessidades. E a assimetria se configura na perspectiva de que as práticas educativas realizam-se por meio da passagem de um saber 
ou informação, dos que "sabem" para os que "desconhecem", negando o diálogo como fundamento dessa relação (Flores, 2007).

A ênfase às ações curativas e ao atendimento médico nos serviços de saúde brasileiros direciona a prática educativa a ações que visam modificar práticas dos indivíduos consideradas inadequadas pelos profissionais, por meio da prescrição de tratamentos, condutas e mudanças de comportamento. Mesmo quando se propõem atividades chamadas participativas, como pela formação de grupos, sua organização prevê prioritariamente aulas ou palestras, restringindo as manifestações dos sujeitos a dúvidas pontuais a serem respondidas pelos profissionais (Chiesa, Veríssimo, 2001).

Em oposição a essa concepção positivista, na qual a educação em saúde é vista de forma reducionista, caracterizada por práticas impositivas e prescritivas de comportamentos, iniciou-se o movimento de transformação da prática tradicional, para um modelo no qual existe a participação ativa da comunidade (Pedrosa, 2007).

Para tanto, a Educação Popular surge como instrumento propulsor desse processo. Por meio da Secretaria de Gestão Estratégica e Participativa (SGEP/MS), o Ministério da Saúde, instituiu a Política Nacional de Educação Popular em Saúde no Sistema Único de Saúde (PNEPS - SUS). Com a PNEPS, os princípios do SUS são reafirmados assim como o compromisso com a garantia do direito à saúde mediante a implementação de políticas que contribuam para a melhoria da qualidade de vida e diminuição das desigualdades sociais, ancoradas na ampliação da democracia participativa no setor saúde (Brasil, 2012).

As ações de Educação Popular em Saúde impulsionam movimentos voltados para a promoção da participação social no processo de formulação e gestão das políticas públicas de saúde direcionando-as para o cumprimento efetivo das diretrizes e dos princípios do SUS, que são: universalidade, integralidade, equidade, descentralização, participação e controle social (Pedrosa, 2007). 
A PNEPS concebe a Educação Popular como práxis políticopedagógica orientadora da construção de processos educativos e de trabalho social emancipatórios, direcionada à promoção da autonomia das pessoas, à horizontalidade entre os saberes populares e os saberes técnico-científicos, à formação da consciência crítica, à cidadania participativa, ao respeito às diversas formas de vida, à superação das desigualdades sociais e de todas as formas de discriminação, violência e opressão (Brasil, 2012).

A Educação Popular não se faz 'para' o povo, e sim, 'com' o povo; procura ainda incorporar os modos de sentir, pensar e agir dos grupos populares, configurando-se assim, como referencial básico para gestão participativa em saúde (Brasil, 2012).

Nesse contexto, a Oficina Pedagógica insere-se como estratégia capaz de garantir o espaço dialógico e a horizontalidade da relação entre profissionais e usuários. O trabalho com oficinas pressupõe uma sequência de encontros com uma temática geral delimitada e apresentada para permitir a participação voluntária da população (Chiesa, Veríssimo, 2001).

A partir do relato dos participantes acerca das suas construções, desencadeia-se a discussão; esta, por sua vez, permite que se compartilhem conhecimentos e vivências. Com isso, é possível trabalhar no sentido da superação do "senso comum", buscando uma compreensão da realidade que estabeleça as articulações entre as dimensões singular, particular e estrutural da realidade, como também analisando o conhecimento científico e resgatando $\circ$ conhecimento empírico, ampliando-se as possibilidades de interpretação dos problemas e a busca de seus enfrentamentos, sob o ponto de vista individual e coletivo (Chiesa, Veríssimo, 2001).

Estudos realizados com o intuito de avaliar o efeito de oficinas educativas têm demonstrado impacto positivo. Após avaliar a resposta dos participantes antes e após realização de oficinas educativas sobre o HIV/AIDS envolvendo a população idosa, houve 
mudança nos conhecimentos relativos ao conceito, transmissão, prevenção, vulnerabilidade e tratamento (Lazzarotto et al., 2013).

Em relato de experiência sobre a realização de oficina educativa também com idosos, mas com o tema uso de medicamentos, os autores indicaram que o espaço dialógico possibilitado pelas oficinas permitiu a interação entre o grupo, a expressão de vivências e a desmistificação de ideias e conceitos acerca do uso de medicamentos (Mendonça et al., 2013).

Com adolescentes, estratégias lúdicas e dialógicas propostas direcionadas à educação em saúde auditiva de escolares, foram aceitas e apreciadas pelos mesmos (Lacerda et al., 2013).

Esses achados comprovam o quanto a Oficina Pedagógica tem se mostrado positiva para a educação em saúde.

\subsection{A ESCOLHA DO TEMA PARA A OFICINA PEDAGÓGICA}

A trajetória profissional bem como as atividades do Grupo de Pesquisa "Cuidado em Saúde e Promoção do Desenvolvimento Infantil" delinearam a escolha do tema da Oficina Pedagógica: a promoção do desenvolvimento infantil de lactentes por meio do brincar no ambiente doméstico.

Contudo, o embasamento científico se faz necessário, na medida em que confirma essa necessidade a partir das evidências apresentadas pelos estudos.

Para isso, foi realizada uma revisão da literatura, que será aqui apresentada como complemento dessa trajetória de escolha. 


\subsubsection{Promovendo o desenvolvimento infantil: o brincar no contexto familiar}

A busca de artigos na literatura científica teve como objetivo compreender o brincar no contexto familiar.

A questão que norteou este estudo foi: Como o brincar tem sido vivenciado no contexto de família?

O período estabelecido foi entre os anos de 2005 e 2014. A pesquisa foi realizada nos seguintes bancos de dados informatizados: Biblioteca Virtual em Saúde (BVS), Cumulative Index of Nursing and Allied Health Literature (CINAHL) e Psycinfo. Os descritores utilizados foram: desenvolvimento infantil, pais, família e brincar.

Um profissional bibliotecário auxiliou na definição do período de abrangência da revisão e na escolha das bases de dados a serem pesquisadas.

Foram pré-selecionados os artigos com resumos disponíveis, relacionados ao brincar no contexto familiar, nos idiomas em português, inglês ou espanhol. Foram excluídos os estudos que tiveram como temática o brincar com fins terapêuticos, além das revisões da literatura e as teses.

Nove artigos atenderam aos critérios, sendo adquiridos e analisados na íntegra. A distribuição segundo a Base de Dados e ano de publicação pode ser visualizada na Tabela 1. 
Tabela 1 - Distribuição dos artigos sobre o brincar com a criança no contexto familiar encontrados e selecionados, segundo as Bases de Dados.

\begin{tabular}{lcccc}
\hline $\begin{array}{c}\text { Base de } \\
\text { dados }\end{array}$ & $\begin{array}{c}\text { Artigos do } \\
\text { período } \\
2005-2014 \\
(\mathbf{N})\end{array}$ & $\begin{array}{c}\text { Pré } \\
\text { Selecionados } \\
(\mathrm{N})\end{array}$ & $\begin{array}{c}\text { Repetidos } \\
(\mathrm{N})\end{array}$ & $\begin{array}{c}\text { Selecionados } \\
\text { para o } \\
\text { estudo (N) }\end{array}$ \\
\hline BVS & 561 & 06 & --- & 06 \\
Cinahl & 120 & 02 & 02 & ---- \\
Psycinfo & 1286 & 03 & --- & 03 \\
\hline Total & $\mathbf{1 9 6 7}$ & $\mathbf{1 1}$ & $\mathbf{0 2}$ & $\mathbf{0 9}$ \\
\hline
\end{tabular}

Fonte: Dados da pesquisa, 2014.

Em relação ao ano de publicação, apresentaram um artigo publicado os anos de 2007, 2009, 2010. Enquanto que os anos de 2006, 2012 e 2014 apresentaram duas publicações em cada ano. Os anos de 2005, 2008, 2011 e 2013 não apresentaram resultado.

Quanto à origem das publicações, houve homogeneidade nos resultados, com quatro estudos nacionais e cinco estudos internacionais.

A abordagem metodológica mais adotada foi a qualitativa, em sete artigos, seja em relatos de experiência, como também em pesquisas que utilizaram a teoria fundamentada nos dados e a etnografia. Dois estudos, de origem internacional, adotaram a abordagem quantitativa.

Dentre os objetivos das pesquisas, estiveram presentes: a identificação das concepções atribuídas pelos familiares acerca do brincar com a criança; a descrição dessa relação; e a avaliação de intervenção, visando o incentivo do brincar entre pais e filhos.

Em relação à formação acadêmica dos pesquisadores, dentre os que a explicitaram, foram encontrados profissionais da área da psicologia e educação física. 
A busca, bem como a análise dos estudos encontrados, permitiu a identificação de poucas pesquisas sobre a brincadeira no contexto das relações familiares com fins de promoção do desenvolvimento infantil. Na busca bibliográfica, durante a leitura dos resumos, foram encontrados muitos artigos focando o brincar da criança e seus pais com fins terapêuticos, em situações específicas de intervenção, como violência familiar, crianças com paralisia cerebral ou distúrbios de aprendizagem.

Um estudo selecionado buscou analisar o cotidiano, na primeira infância, numa cidade do interior de São Paulo, e verificar as oportunidades oferecidas para a criança brincar. Por meio do Formulário para Avaliação das Atividades do Cotidiano Infantil (FACl), que se refere à percepção de tempo gasto em diferentes atividades durante o dia, constatou-se que as atividades que mais estão sendo realizadas durante a semana em casa são: muitas horas na frente da televisão, games e internet ( $>2$ horas diárias) e o brincar com brinquedos industrializados, deixando brincadeiras que contenham um gasto calórico mais elevado para segundo plano. Sobre os lugares em que as crianças brincam, verificou-se que a maioria fica dentro de casa, na garagem ou no quintal. Lugares como praças, parques, clubes, casas dos vizinhos são raramente frequentados (Coelho, Fermino, 2012).

Muitas vezes, os próprios pais restringem 0 brincar enfatizando a excelência acadêmica, para que seus filhos atendam às demandas escolares, ainda que, quando questionados sobre a importância do brincar, relatem que a brincadeira é importante tendo em vista seus aspectos de aprendizagem, saúde e bem-estar (Singh, Gupta, 2014).

Quando se buscou identificar as relações entre pais e filhos nas situações de brincadeira, apareceu uma relação pouco participativa do adulto com a criança. Estudo, com sete casais identificou que quatro colocaram a brincadeira como espaço 
exclusivo das crianças e três indicaram a importância em participar e orientar a brincadeira dos seus filhos (Bustamante, Trad, 2007), ou seja, as famílias, em geral, não relatam participar das atividades de brincar.

No caso de famílias de baixa renda, estudo demonstrou que os brinquedos são poucos e conseguidos com dificuldade, devido à condição financeira dos pais; além disso, o cuidado com os brinquedos é tão grande que, às vezes, as crianças nem chegam a brincar muito, principalmente com aqueles mais caros, eventualmente ganhos e, aos pais, cabe a participação com a finalidade de supervisão.

É importante compreender que a brincadeira inserida no contexto de família não só representa um meio facilitador para os pais e mães educarem seus filhos, mas também representa uma prática educativa em si, já que, por seu intermédio, as famílias e suas crianças podem trocar informações para a formação de laços afetivos, socialização e constituição do sujeito social (Martins, Szymanski, 2006).

Estudo realizado com famílias envolvendo intervenções lúdicas com participação dos pais em domicílio evidenciou mudança no comportamento desses pais no dia a dia, com aumento da sua participação nas atividades lúdicas de seus filhos. Os pais observaram que os aspectos que mais se alteraram, durante esse período de intervenção, foram o desenvolvimento motor, cognitivo, linguagem e autocuidados (Scalha, Souza, Boffi, 2010).

Com isso, os dados indicam a necessidade de promover 0 conhecimento das famílias acerca da importância do brincar com as crianças, com foco no desenvolvimento infantil. Intervenções educativas se mostraram efetivas, sendo norteadoras para a implementação de práticas adequadas.

No Brasil, além das políticas públicas instituídas pelo Ministério da Saúde, encontramos programas de orientação familiar 
específicos visando à garantia da promoção do desenvolvimento da criança.

Dentre eles, o Programa Primeira Infância Melhor (PIM) que "integra a política de governo do Estado do Rio Grande do Sul, sob a coordenação da Secretaria da Saúde e apoio das Secretarias da Educação, Cultura, Trabalho e Desenvolvimento Social”. Desenvolvido desde 2003, realiza ação socioeducativa às famílias com crianças de zero até seis anos e gestantes em situação de vulnerabilidade social. As famílias são orientadas por meio de atividades lúdicas específicas, voltadas à promoção das habilidades/capacidades das crianças, considerando seu contexto cultural, suas necessidades e interesses, por meio de atendimentos semanais realizados nas casas das famílias, além das atividades comunitárias.

Contudo, programas desse porte, baseados em visitação semanal, demandam grande investimento, o que pode dificultar sua implantação em larga escala.

Assim, é necessário buscar diferentes estratégias no âmbito da assistência em saúde para garantir acesso às informações, troca de experiências e construção do saber por parte dos familiares, para que as crianças sejam assistidas em sua plenitude, e seus direitos garantidos em excelência.

\subsection{A ESCOLHA DA FAIXA ETÁRIA DAS CRIANÇAS}

Em relação à faixa etária da criança escolhida para abrangência deste estudo, é importante destacar os quatro domínios inter-relacionados de desenvolvimento infantil (DI): físico, cognitivo, linguístico e socioemocional. Estes serão sintetizados a seguir, tendo como referência Naudeau et al. (2011).

O desenvolvimento físico é definido como uma taxa individual de crescimento, aptidão física, habilidades motoras finas, 
habilidades motoras grosseiras e capacidade de cuidar de si mesmo; pode ser afetado negativamente pela presença de condições crônicas, deficiência física e desnutrição.

O desenvolvimento cognitivo envolve progressos nas habilidades analíticas, de resolução de problemas mentais, memória, e nas habilidades matemáticas. Conforme as crianças vão se aproximando da idade escolar, o desenvolvimento cognitivo amplia seu alcance para o conhecimento precoce dos números, incluindo adição e subtração, e a familiaridade com as letras do alfabeto e letras impressas.

O desenvolvimento da linguagem, por sua vez, se manifesta inicialmente no recém-nascido pelos atos de balbuciar, apontar e gesticular, e depois pelo surgimento das primeiras palavras e frases enquanto bebê, até a explosão de palavras entre as idades de dois e três anos. Antes que a criança possa realmente falar, ela é capaz de absorver a linguagem e distinguir sons, o que indica que é de fundamental importância que os pais/cuidadores interajam verbalmente com as crianças desde o nascimento. Quando as crianças chegam à idade pré-escolar, os indicadores de desenvolvimento da linguagem incluem a produção $e$ a compreensão de palavras, a capacidade de contar histórias e identificar letras e a intimidade e familiaridade com os livros.

Já o desenvolvimento social e emocional nos primeiros dois anos de vida gira em torno do relacionamento das crianças com seus cuidadores, por meio da confiança. $\mathrm{Na}$ idade pré-escolar, o desenvolvimento social e emocional se constroi sobre as aquisições anteriores e se expande para incluir a competência social (conviver com outras pessoas, inclusive colegas e professores), a gestão de comportamento (seguir instruções e cooperar com os pedidos), a percepção social (identificar pensamentos e sentimentos em si e nos outros), e capacidades de autocontrole (ter controle emocional e comportamental, especialmente em situações de estresse). 
Existem intervenções particularmente importantes em cada período do desenvolvimento da primeira infância (DPI), devendo ser priorizadas nas decisões sobre as intervenções apropriadas para diferentes grupos etários. O Quadro 1 resume os tipos de intervenções mais relevantes durante os diferentes períodos.

Quadro 1 - A importância do tempo: as intervenções mais importantes para a promoção do desenvolvimento no período pré-escolar, segundo os domínios do desenvolvimento e a idade da criança.

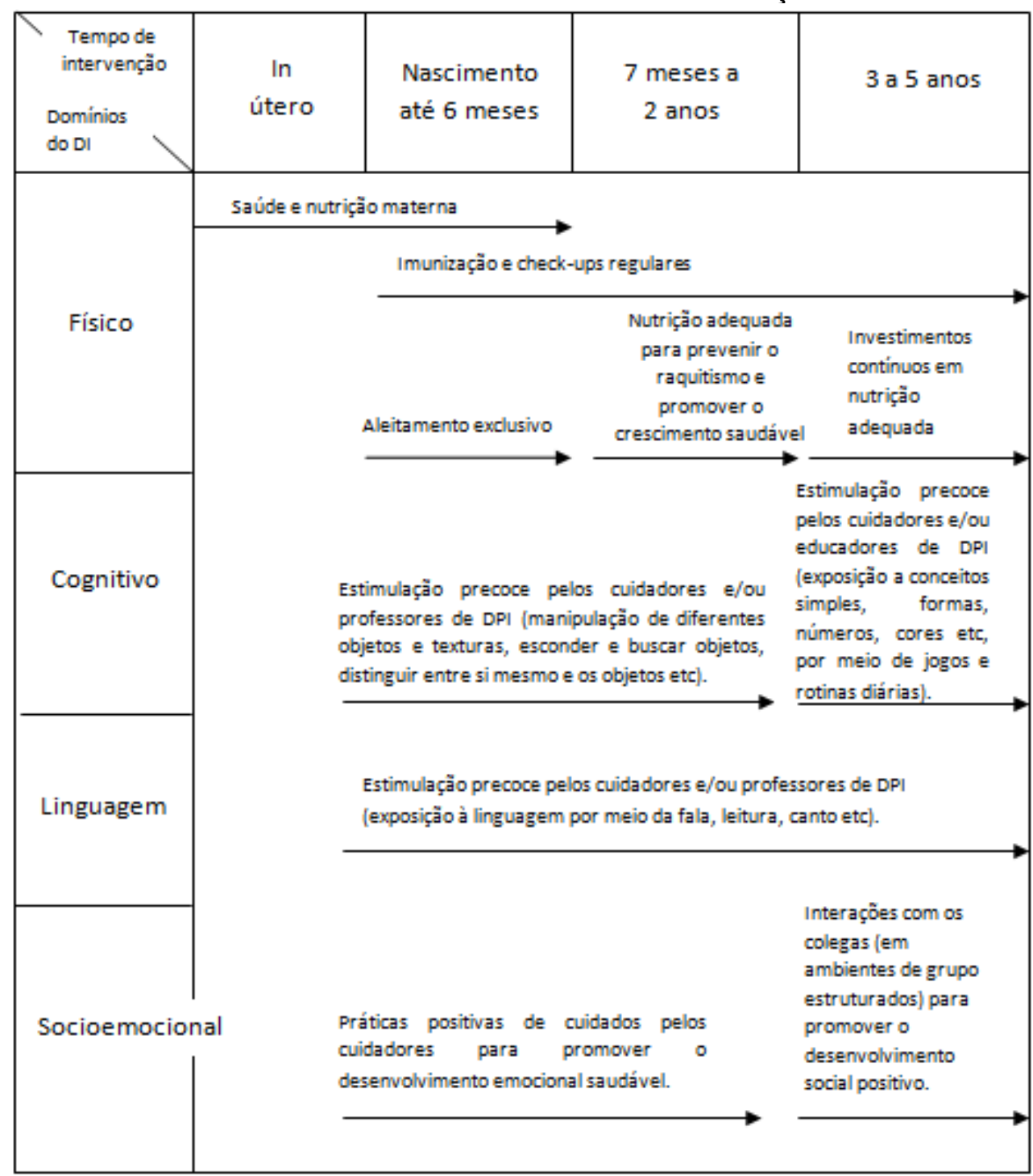

Fonte: Naudeau et al. Como investir na primeira infância: um guia para a discussão de políticas e a preparação de projetos de desenvolvimento da primeira infância. Tradução: Paola Morsello. Washington, DC: The World Bank, 2010; São Paulo: Singular, 2011. 
Pelo exposto, a faixa etária que envolve os lactentes foi escolhida. O Ministério da Saúde considera lactente o período compreendido entre 29 dias de vida da criança até os 2 anos de idade (Brasil, 2004). Essa faixa etária corresponde a de menor interação dos pais, conforme observação da prática assistencial.

Justifica-se a seleção dessa faixa etária, pois os primeiros anos de vida da criança tratam-se do período mais crítico e o mais vulnerável no desenvolvimento (Brazelton, Greenspan, 2002) e, para o trabalho com dinâmica de grupo, considerou-se pertinente essa variação de faixa etária, tendo em vista a grande variabilidade de fases do desenvolvimento envolvidas em uma faixa mais ampliada.

\subsection{JUSTIFICATIVA DO ESTUDO}

A justificativa para realização deste estudo baseia-se em sua relevância acadêmica e social, além de subsidiar a prática de educação em saúde exercida pelo enfermeiro.

Com relação à contribuição acadêmica, o estudo pretende contribuir com o conhecimento sobre o nível de estimulação que as crianças estão recebendo de suas famílias no ambiente doméstico, bem como com a proposição de estratégias passíveis de execução no âmbito da educação em saúde. Sendo que essas estratégias foram construídas em conjunto com os usuários dos serviços, igualmente sujeitos do processo.

Ainda na interface acadêmica, o estudo contribuirá para a formação cientifica da pesquisadora, visando a contribuição para o conhecimento a ser aplicado na assistência e no ensino.

Para o cenário social, os resultados da pesquisa devem contribuir para a produção dos saberes de maneira que os sujeitos sejam protagonistas do processo de cuidado e decisões. Com o 
cuidado respaldado pelo conhecimento, o desenvolvimento da criança será melhor promovido no dia a dia por seus familiares.

O estudo também pretende apresentar subsídios para a melhoria da prática assistencial do enfermeiro, visto que a educação em saúde tem se mostrado como ferramenta eficaz e de baixo custo.

Ademais, a identificação de que a interação da criança pequena com 0 adulto em relação à estimulação do desenvolvimento por meio do brincar é pouca, fomenta a busca por estratégias que possam promover o conhecimento e a apropriação de práticas de cuidado capazes de garantir a estimulação do desenvolvimento infantil.

Com isso, a questão que conduziu o desenvolvimento do estudo foi: A ação educativa, no modelo de Oficina Pedagógica, tem efeito sobre os conhecimentos e práticas dos familiares de lactentes sobre a promoção do desenvolvimento infantil por meio da brincadeira? 
OBJETIVOS 


\section{OBJETIVOS}

\subsection{OBJETIVO GERAL}

- Avaliar o efeito de uma atividade educativa sobre os conhecimentos e práticas dos familiares de lactentes relativos à promoção do desenvolvimento infantil por meio do brincar.

\subsection{OBJETIVOS ESPECÍFICOS}

- Avaliar a qualidade de estimulação no ambiente doméstico antes e após a realização de uma ação educativa.

- Planejar e realizar uma ação educativa na modalidade de Oficina Pedagógica, sobre desenvolvimento infantil e brincadeira.

- Descrever a opinião das participantes sobre a atividade educativa realizada.

- Descrever as facilidades e dificuldades na execução da ação educativa. 
MÉTODO 


\section{MÉTODO}

\subsection{TIPO DE ESTUDO}

Trata-se de um estudo quantitativo, com delineamento experimental, longitudinal, prospectivo e naturalista.

$O$ estudo experimental permite que o pesquisador seja um agente ativo no processo, mais do que um observador passivo. As pesquisas experimentais se caracterizam por três propriedades principais: 1) manipulação: o pesquisador faz alguma coisa aos participantes do estudo - no caso desta pesquisa, a ação educativa, no modelo de oficina pedagógica, foi escolhida como experimento a ser testado, 2) controle: o pesquisador introduz controles sobre a situação experimental, incluindo o uso do grupo de controle, 3) randomização: o pesquisador designa aleatoriamente os participantes para os grupos de controle e experimental (Polit, Beck, Hunger, 2004).

Em relação ao experimento, este estudo se caracteriza pelo delineamento pré-teste/pós-teste ou delineamento anterior-posterior, que envolve a coleta de dados, antes da manipulação experimental, o pré-teste, e nova coleta dos dados depois dela, o pós-teste (Polit, Beck, Hunger, 2004).

Quanto às outras características do delineamento, esta pesquisa é longitudinal, pois os dados foram coletados em mais de uma ocasião durante o período de coleta. É prospectivo, na medida em que começou com uma variável independente e olha para frente em busca do efeito. E é naturalista, pois os dados foram coletados no ambiente natural, ou seja, sem ser um ambiente artificial, forçado (Polit, Beck, Hunger, 2004).

O método quantitativo com esses delineamentos foi escolhido com o intuito de avaliar uma ação educativa, pois permite a análise de aspectos mensuráveis que podem se comportar como indicadores de efetividade da ação realizada. Em pesquisas quantitativas, as pesquisas avaliativas baseiam-se na avaliação 
objetiva, não tendenciosa e imparcial das forças e limitações do estudo (Lo-Biondo, Haber, 2001).

\subsection{CENÁRIO DO ESTUDO}

O estudo foi realizado no município de Sorocaba, interior de São Paulo, no bairro Aparecidinha, localizado na zona leste e a 14 km de distância do centro da cidade. Trata-se de um bairro industrial e residencial, onde reside uma população de baixa renda, estimada em 10.000 habitantes, segundo dados do Instituto Brasileiro de Geografia e Estatística - IBGE (2010), incluindo a população carcerária.

O bairro ainda sofre com problemas de infraestrutura, destacando-se o esgoto a céu aberto em algumas áreas e os poucos locais de comércio, como bancos, cartórios, correios, além dos déficits no transporte público para acesso ao centro da cidade, lazer e moradia.

Possui duas escolas estaduais, uma escola de futebol, quatro creches, um Centro de Referência de Assistência Social (CRAS), a Pastoral do Menor que abriga o Projeto Primeiro Emprego, em que adolescentes de 14 a 17 anos são preparados para inserção no mercado de trabalho, o Presídio de Aparecidinha, que é a maior penitenciária da região, a Fundação Casa de Sorocaba (FEBEM), o Centro de Detenção Provisória (CDP) e uma Unidade de Saúde Estratégia Saúde da Família (ESF).

Inaugurada em 1994, a Unidade Estratégia Saúde da Família (ESF) é a única do bairro, contando com quatro equipes para acompanhamento das famílias. Uma equipe é responsável por 450 famílias, e as outras três são responsáveis por 900 famílias cada.

A equipe de profissionais atuantes na unidade é composta por uma gestora (enfermeira), quatro médicos, quatro enfermeiros assistenciais, quatro residentes em enfermagem, três dentistas e uma equipe de residência em saúde mental, composta por um terapeuta ocupacional e uma psicóloga. 
Ao redor do bairro Aparecidinha, estão outros bairros - Jardim Monteiro, Jardim Josane, Jardim Topázio, Jardim das Flores, Vila Amato -, e uma extensa e difusa zona rural abrangendo os municípios limítrofes como Itu, Mairinque e Alumínio, o que gera também procura por atendimento desses moradores na ESF.

Em relação ao atendimento infantil, a unidade conta com dois pediatras, para uma população de 396 crianças menores de 2 anos. Essas crianças também são acompanhadas pelos médicos generalistas e enfermeiros, além dos agentes comunitários de saúde (ACS) que monitoram mensalmente 0 acompanhamento das consultas médicas e de enfermagem, as vacinas e o ganho ponderal.

Há também um grupo educativo para os pais semanalmente, discorrendo sobre os temas amamentação, cuidados com a criança, etapas de desenvolvimento, entre outros assuntos.

A escolha por esta unidade se deu pelo fato de não ser o local de trabalho da pesquisadora, fato este que poderia influenciar os participantes por se tratar da avaliação de uma atividade educativa desenvolvida pela própria pesquisadora. Além da possibilidade de contar com a participação voluntária da enfermeira da unidade na coleta de dados.

\subsection{POPULAÇÃO DO ESTUDO}

A população do estudo constitui-se de cuidadores de crianças com idade entre 1 e 24 meses, cadastradas na Unidade Estratégia Saúde da Família do bairro, perfazendo, portanto, uma amostra de conveniência.

Foram considerados como critérios de inclusão:

- ser o cuidador primário da criança,

- ter a capacidade de se expressar verbalmente,

- ser maior de 16 anos de idade. 


\subsection{COLETA DE DADOS}

A coleta de dados foi realizada em três momentos; o esquema a seguir sintetiza essas etapas, posteriormente detalhadas.

Esquema 1 - Etapas da Coleta de Dados.

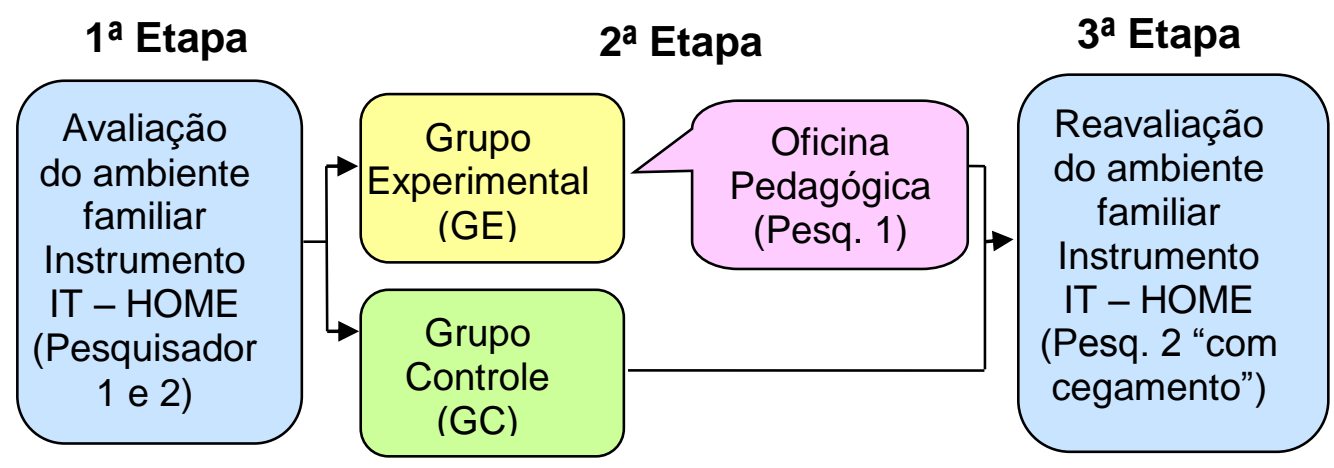

Fonte: Dados da Pesquisa, Sorocaba, 2015.

\subsubsection{Primeira etapa}

Esta etapa precedeu a realização da ação educativa e foi realizada com o intuito de identificar o nível de estimulação que as crianças recebiam de seus cuidadores primários no ambiente doméstico. Para isso, foi aplicado o inventário Home Observation for Measurement of the Environment Scale (HOME).

Esse instrumento foi desenvolvido e validado por Caldwell e Bradley, em 1984, com o objetivo de mensurar a qualidade e a quantidade de estimulação e suporte disponíveis para a criança no ambiente doméstico, e a relação destes com o desenvolvimento social, emocional e cognitivo da criança (Caldwell, Bradley, 2001).

Existem quatro versões desse instrumento, que avaliam o ambiente desde o nascimento até a pré-adolescência: 1) Inventário HOME versão Infant Toddler (IT-HOME), avalia crianças desde o nascimento até os três anos de idade; 2) Inventário HOME versão Early Childhood (EC-HOME) destinado a crianças entre três a seis anos; 3) Inventário HOME versão Middle Childhood (MC-HOME), para avaliação de crianças entre seis e dez anos; e 4) Inventário 
HOME versão Early Adolescent (EA-HOME), voltado a crianças e pré-adolescentes com idade entre 10 e 14 anos (Caldwell, Bradley, 2001).

Para este estudo, utilizou-se a versão Infant Toddler (ITHOME) (Anexo 1), adequado ao grupo etário da pesquisa.

A versão para esse grupo etário é composta por 45 itens dicotômicos, preenchidos com base na observação das interações da criança com seu cuidador e nas respostas obtidas por meio de entrevista com esse cuidador, devendo ser aplicado no ambiente em que a criança passa a maior parte do tempo (Caldwell, Bradley, 2001).

Os 45 itens são distribuídos em seis subescalas de avaliação: I) responsividade emocional e verbal da mãe; II) ausência de punição e restrição; III) organização do ambiente físico e temporal; IV) disponibilidade de materiais, brinquedos e jogos apropriados; V) envolvimento materno com a criança; VI) oportunidade de variação na estimulação diária.

O Roteiro Prático para Aplicação do $\operatorname{HOME~}(0-3 \text { anos })^{1}$ conduz, por meio de orientações gerais, a aplicação do instrumento, pontuando questões que devem ser atentadas em cada subescala.

Na subescala "Responsividade emocional e verbal da mãe" é necessário observar a interação da mãe com a criança bem como suas manifestações de afeto. Também é pontuado o interesse da mãe pela entrevista, se ensina a criança o nome de algum objeto ou pessoa durante esse contato, e se permite que a mesma envolva-se em brincadeiras que possam sujar a si própria ou o ambiente.

Em "Ausência de punição e restrição" avalia-se a presença de xingamentos emitidos pela mãe e direcionados à criança, a aplicação de punições físicas ou ameaças, a existência de livros no ambiente doméstico e a presença de um animal de estimação.

\footnotetext{
${ }^{1}$ Material cedido pela autora, pois não havia sido publicado.
} 
Na subescala "Organização do ambiente físico e temporal" considera-se, por exemplo, os passeios propiciados à criança, a presença de um lugar para guardar seus brinquedos e a segurança do espaço para brincar. Em "Disponibilidade de materiais, brinquedos e jogos apropriados" avalia-se a presença de brinquedos e objetos apropriados à aprendizagem e ao desenvolvimento muscular e coordenação viso-motora, bem como as atividades proporcionadas à criança, de acordo com sua idade.

No "Envolvimento materno com a criança" é identificado se a mãe tende a conversar e olhar para a criança, se investe em brinquedos mais complexos, se organiza o tempo para brincar com a criança e se conscientemente encoraja seu desenvolvimento, sendo que para isso é preciso compreender como ocorre esse processo de desenvolvimento.

E em "Oportunidade de variação na estimulação diária" são consideradas as interações entre o pai e outras pessoas e a disposição do cuidador para a leitura, podendo esta ser um conto de fadas, história em quadrinhos ou livros religiosos.

Em relação aos brinquedos, o instrumento considera a presença de brinquedo de sucata ou objetos que exerçam a mesma função, desde que a criança tenha acesso irrestrito ao material.

Em cada subescala há itens de observação, itens de entrevista e itens que podem ser observados ou perguntados ao cuidador. Com isso, dos 45 itens, 18 são obtidos por observação, 24 por entrevista e 3 podem ser obtidos por observação ou entrevista.

Cada item recebe zero ou um ponto, de acordo com a ausência ou presença do comportamento avaliado, respectivamente. Assim, a pontuação total varia entre 0 e 45 pontos, permitindo a classificação de risco no ambiente doméstico sendo possível a avaliação pelo escore total bem como pelas subescalas (Tabela 2). 
Tabela 2 - IT HOME: escore bruto das subescalas e escore total.

\begin{tabular}{lccc}
\hline \multicolumn{1}{c}{ Subescala } & $\begin{array}{c}\text { Menor que } \\
\text { à } \mathbf{4}^{\mathbf{a}} \text { parte }\end{array}$ & Médio & $\begin{array}{c}\text { Superior } \\
\text { à } \mathbf{4}^{\mathbf{a}} \text { parte }\end{array}$ \\
\hline I. Responsividade & $0-6$ & $7-9$ & $10-11$ \\
II. Aceitação & $0-4$ & $5-6$ & $7-8$ \\
III. Organização & $0-3$ & $4-5$ & 6 \\
IV. Materiais & $0-4$ & $5-7$ & $8-9$ \\
V. Envolvimento & $0-2$ & $3-4$ & $5-6$ \\
VI. Variedade & $0-1$ & $2-3$ & $4-5$ \\
\hline Escore Total & $\mathbf{0 - 2 5}$ & $\mathbf{2 6 - 3 6}$ & $\mathbf{3 7 - 4 5}$ \\
\hline
\end{tabular}

Os valores considerados "Inferiores à $4^{\mathrm{a}}$ parte" indicam alto risco, ou seja, trata-se de um ambiente com baixo nível de estimulação. Os de "Nível médio" referem-se aos ambientes com médio nível estimulação e os valores "Superiores à 4a parte" indicam baixo risco, portanto, ambiente com alto nível de estimulação.

Dentre as dimensões mensuráveis pelo instrumento, constam avaliações relativas à interação da criança com seu cuidador envolvendo a brincadeira e o brinquedo, por isso sua escolha para este estudo, além de ser um instrumento validado.

Sua aplicação foi realizada por duas pesquisadoras, sendo uma a autora e a outra voluntária e enfermeira da ESF, no ambiente doméstico de cada criança. Antes do início das visitas domiciliares, foi realizada a leitura e discussão do Roteiro Prático para Aplicação do HOME $(0-3$ anos $)$ pelas pesquisadoras, para treinamento e definição de condutas.

A escolha dos domicílios foi conduzida pela pesquisadora voluntária, enfermeira da ESF, por conhecer o bairro e por fazer parte da sua rotina de acompanhamento das famílias. Nessas visitas de rotina, era identificada a possibilidade de inclusão no estudo, 
considerando os critérios de inclusão e, se dentro desses critérios, o cuidador primário da criança era convidado a participar do estudo, sendo apresentado o Termo de Consentimento Livre e Esclarecido TCLE (Apêndice A).

O período de coleta de dados dessa etapa foi de 26 de março a 11 de junho de 2015.

Além do IT - HOME, foram utilizadas questões para caracterização do cuidador primário da criança (sexo, relação com a criança, idade, escolaridade e inserção em atividade remunerada) e da criança (sexo, idade e frequência em creche).

Usou-se também o Critério de Classificação Econômica Brasil da Associação Brasileira de Empresas e Pesquisa - ABEP, versão 2014, para classificação do nível econômico das famílias (Anexo 2).

Para estabelecer os diferentes estratos econômicos, o questionário $\mathrm{ABEP}$ se baseia no poder de consumo - bens materiais e serviço - além da escolaridade do chefe da família. Os escores variam entre a pontuação mínima de zero e a máxima de 46 pontos, e as famílias são distribuídas nas classes A1, A2, B1, B2, C1, C2, D e $E$. As classes $A$ representam a melhor situação, seguida das classes $B, C, D$ consideradas intermediárias e a classe $E$ representa a pior situação econômica.

Encerrou-se a coleta desta fase quando as visitas não estavam mais repercutindo em novos participantes, seja pela ausência da criança no domicílio, fato imprescindível para a coleta de dados, ou por não ter sido encontrado alguém na residência. Além de se já ter atingido o tamanho mínimo da amostra.

A partir dos dados obtidos, a amostra foi pareada para formação do Grupo Experimental (GE) e Grupo Controle (GC). Para obtenção da homogeneidade entre os dois grupos foram considerados como critérios de pareamento: a escolaridade do cuidador primário, a classificação econômica da família e a idade da criança, sendo este último o de maior impacto. Estes critérios foram 
escolhidos uma vez que tais características potencialmente interferem nos conhecimentos e práticas de cuidado à criança.

A escolha de quem faria parte de cada grupo foi realizada por meio de sorteio. Os do GE foram então convidados a participar da ação educativa.

Contudo, dadas as ausências ocorridas na ação educativa, foram realizadas algumas estratégias para ampliar o número de participantes do GE: os faltosos na primeira Oficina Pedagógica foram convidados a participar de um segundo momento, planejado para possibilitar a adesão de quem esteve impossibilitado de comparecer na primeira data. Os participantes do GC também foram convidados a participar da atividade educativa, exceto um que não foi encontrado e um que mudou de bairro. Assim, o GC foi finalmente formado pelos participantes que não compareceram a qualquer momento da atividade.

O convite para participação foi elaborado e impresso pela pesquisadora e entregue na residência dos participantes.

Figura 1 - Modelo do convite entregue aos cuidadores para participação na Oficina Pedagógica.

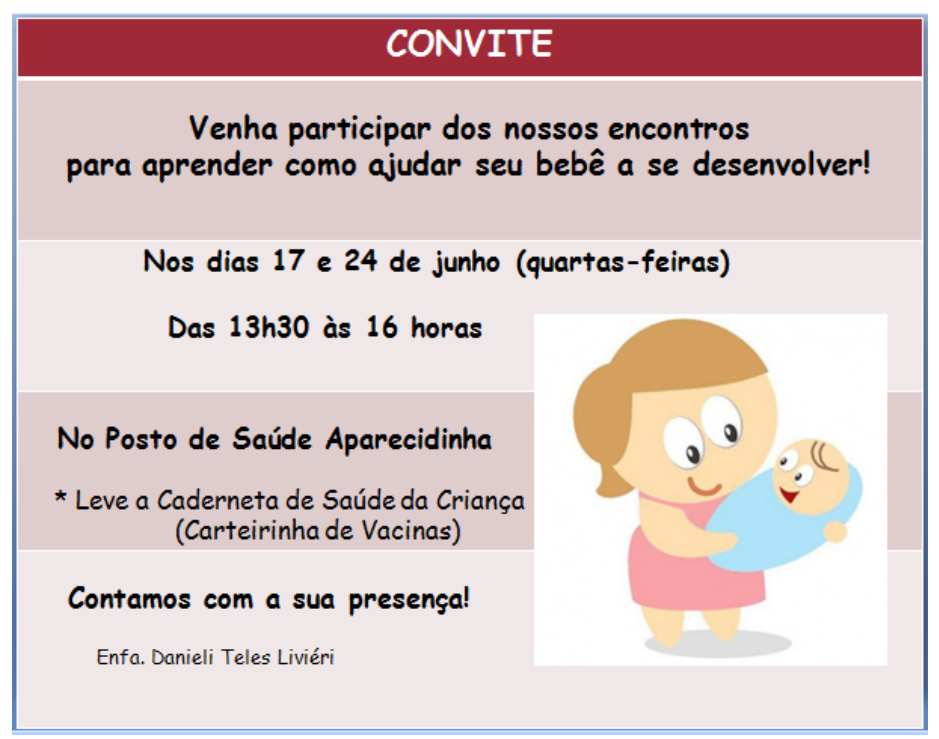

Fonte: Dados da Pesquisa, Sorocaba, 2015. 
Os convites foram plastificados com papel contact e, na parte posterior, foi colocado um imã para que pudessem ser colocados na geladeira ou armário metálico. Foram entregues pelos Agentes Comunitários em Saúde (ACS) em uma caneca infantil visando serem mais atrativos (Figura 2).

A entrega começou cinco dias antes da data do primeiro encontro e terminou dois dias antes. No dia anterior ao primeiro encontro, os participantes foram relembrados da data pelos próprios ACS(s).

Figura 2 - Formato de entrega do convite para participação na Oficina Pedagógica.

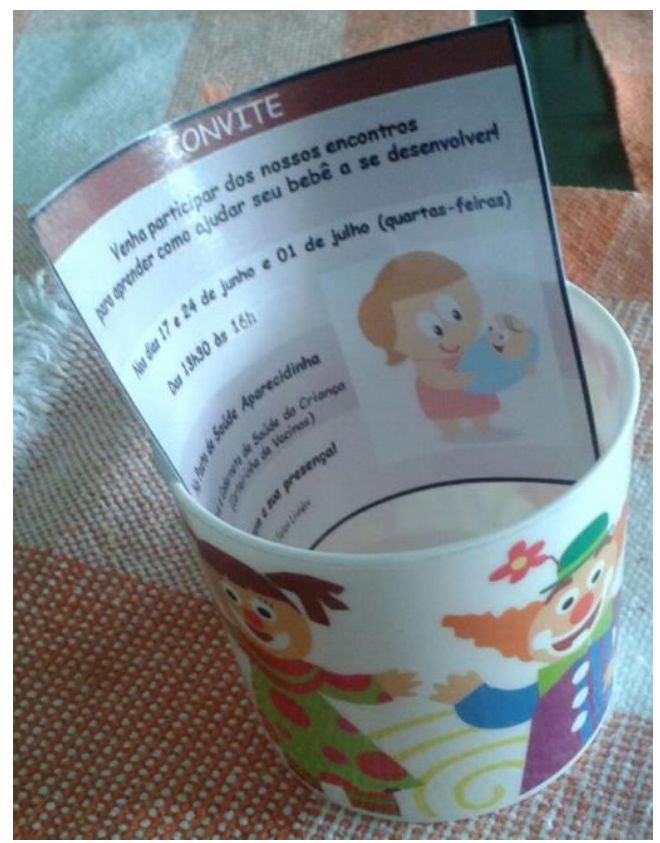

Fonte: Dados da Pesquisa, Sorocaba, 2015.

\subsubsection{Estudo piloto}

Os resultados das primeiras coletas de dados foram enviados ao profissional da estatística para dimensionamento amostral.

Oito entrevistas obtidas por meio do IT - HOME foram tabuladas em planilha Excel e submetidas à avaliação. 
Todas essas entrevistas foram incorporadas na amostra real. Os dados permitiram estimar o número mínimo de participantes em cada grupo, considerando nível de confiança de $95 \%$ e poder de teste de $80 \%$.

Esse período serviu também para que as pesquisadoras se reunissem ao final de cada dia de coleta para discutir as dúvidas que surgiram durante as entrevistas, sendo estas sanadas pelo apoio do Roteiro Prático para Aplicação do HOME (0 - 3 anos).

O estudo piloto não compreendeu, entretanto, a realização de todas as etapas previstas na pesquisa experimental, visto que a ação educativa não foi realizada nessa pequena amostra inicial. Com isso, a amostra foi dimensionada a partir dos primeiros dados obtidos considerando-se impacto positivo da ação educativa no comportamento dos participantes.

\subsubsection{Segunda etapa}

Esta etapa compreendeu a realização de duas Oficinas Pedagógicas, cada uma composta por dois encontros. Os participantes das oficinas compuseram o Grupo Experimental (GE) e os que não participaram compuseram o Grupo Controle (GC).

Os temas gerais abordados na ação educativa foram: "Compreendendo o desenvolvimento infantil" e "Promovendo o desenvolvimento infantil por meio do brincar".

A oficina foi construída tendo como referência a estrutura pedagógica do "Projeto Nossas Crianças: Janelas de Oportunidades"2 e o caderno de "Formação em Espaços Lúdicos"3 produzido pela Fundação Maria Cecília Souto Vidigal (FMCSV) com o apoio do Centro de Criação de Imagem Popular (Cecip).

\footnotetext{
${ }^{2}$ Material cedido pelos formadores do projeto, pois não havia sido publicado.

3 Disponível on line em http://www.fmcsv.org.br/pt-br/acervodigital/Paginas/formacao-em-espacos-ludicos.aspx.
} 
O Projeto Janelas tem como meta empoderar as famílias na promoção do desenvolvimento infantil, mediante compartilhamento do conhecimento e ampliação de sua participação no processo de atenção à saúde da criança (Martins, Veríssimo, Oliveira, 2008).

Já o caderno de "Formação em Espaços Lúdicos" trata-se de uma ferramenta voltada à disseminação de conhecimentos sobre o desenvolvimento integral da criança de zero a três anos, com o objetivo de gerar ações integradas de saúde, educação e desenvolvimento social e modificar o panorama do atendimento às necessidades e direitos da primeiríssima infância (Saviani, 2014).

Para tanto, o referencial teórico que orientou a organização da ação educativa foi o da Educação Popular de Paulo Freire, em seus eixos norteadores da problematização e dialogicidade.

As ideias do educador Paulo Freire têm sido referência para a área da educação em saúde no que concerne ao delineamento de estratégias educativas que fortaleçam a participação dos usuários nos serviços de saúde (Sá et al., 2013).

Todo profissional de saúde é um educador em potencial e pode contribuir para o diálogo e para a troca de saberes técnico-científicos e populares. Desse modo, profissionais e usuários podem construir de forma compartilhada um saber em saúde, que promova mudanças de hábitos e de comportamentos, utilizando-se de técnicas educativas que promovam a reflexão e a crítica (Sá et al., 2013).

Ensinar não é transferir conhecimento, mas criar as possibilidades para a sua produção ou construção. Ensinar é, portanto, buscar, indagar, constatar, intervir, educar. $O$ ato de ensinar exige conhecimento e, consequentemente, a troca de saberes. Pressupõe-se a presença de indivíduos que, juntos, trocarão experiências de novas informações adquiridas, respeitando também os saberes do senso comum e a capacidade criadora de cada um (Freire, 1996). 
"Nas condições de verdadeira aprendizagem os educandos vão se transformando em reais sujeitos da construção e da reconstrução do saber ensinado, ao lado do educador, igualmente sujeito do processo" (Freire, 1996, p. 26).

A prática problematizadora promove o diálogo entre os profissionais e usuários e a autonomia cidadã incentivando esses sujeitos a adotarem uma postura ativa em seus ambientes políticos e sociais (Fernandes, Backes, 2010).

Como material de apoio e referencial teórico para os conteúdos abordados na atividade educativa sobre o desenvolvimento infantil e o brincar, foram utilizados, respectivamente: 1) a Caderneta de Saúde da Criança do Ministério da Saúde e 2) o capítulo III do livro "O brincar e a criança do nascimento aos seis anos" (Oliveira et al., 2000), intitulado " $A$ criança pequena e o despertar para o brincar - primeiros dois anos de vida".

A Caderneta de Saúde da Criança é utilizada nacionalmente e, em sua última versão (Brasil, 2013), destina-se ao registro da história de saúde da criança de forma retrospectiva sobre o pré-natal e o nascimento, e de forma prospectiva a partir do nascimento. É entregue para a mãe ainda na maternidade, devendo ser utilizada em todo atendimento ao qual a criança seja submetida, para possibilitar os registros bem como o acompanhamento dos profissionais e da família. A primeira parte é dedicada a quem cuida da criança, contendo informações e orientações para ajudar a cuidar melhor de sua saúde. A segunda parte é destinada aos profissionais de saúde, com algumas orientações acerca do processo de atendimento, como explicações sobre o uso dos gráficos de crescimento e sobre o cuidado de crianças em situações especiais.

O capítulo do livro, por sua vez, apresenta as características essenciais do desenvolvimento na primeira infância bem como as estratégias para sua estimulação por meio do emprego de brinquedos e brincadeiras apropriadas conforme cada faixa etária. 
Os encontros tiveram a periodicidade semanal e foram conduzidos pela própria pesquisadora; as discussões foram gravadas em mídia digital. A pesquisadora voluntária não esteve envolvida nesta etapa, para que, na etapa subsequente, pudesse ter "cegamento" em relação aos participantes que participaram ou não da oficina.

O local de realização das Oficinas foi a sala de atividades educativas da ESF; os encontros aconteceram no período da tarde, conforme disponibilidade de dia da semana e horário da ESF.

A unidade é composta por dois andares, sendo que essa sala fica localizada no andar inferior. O seu acesso é feito pela escadaria antes de entrar na recepção da unidade ou pela outra entrada existente na rua lateral, garantindo assim que a pesquisadora "com cegamento" não tivesse contato com os participantes.

Foi organizado um espaço lúdico para as crianças presentes, contando com a presença de outra voluntária para realização das atividades de recreação.

Os objetivos, as estratégias e os recursos para cada encontro estão dispostos no Apêndice B.

No último dia de cada oficina, foi aplicado aos participantes o Questionário de Avaliação da Oficina Pedagógica (Apêndice C).

\subsubsection{Terceira etapa}

Os participantes do Grupo Experimental (GE) e do Grupo Controle (GC) foram reavaliados a partir da reaplicação do instrumento IT - HOME.

Nesse momento, somente a pesquisadora voluntária participou da coleta, sem saber quais sujeitos tinham participado da ação educativa, sendo, portanto, uma pesquisadora com cegamento. Tal estratégia foi adotada para diminuir os possíveis vieses desta segunda análise, garantindo assim maior fidedignidade aos dados obtidos. 
A coleta ocorreu durante o período de 08 de setembro a 16 de outubro de 2015.

\subsection{ANÁLISE DOS DADOS}

\subsubsection{Primeira etapa:}

Os resultados da caracterização do cuidador primário da criança, da criança e do IT - HOME foram tabulados em planilha Excel e encaminhados para o profissional da estatística.

Foi realizada a análise descritiva dos dados sendo os resultados expressos por frequências e percentuais, ou por médias e desvios padrões.

\subsubsection{Segunda etapa:}

Os registros das oficinas, bem como de sua avaliação pelos participantes, foram descritos, para melhor compreensão da atividade e de seu possível impacto nas práticas familiares.

Os dados resultantes do Questionário de Avaliação da Oficina Pedagógica receberam tratamento estatístico, após tabulação em planilha do Excel.

Os resultados foram expressos por frequências e percentuais ou por médias e desvios padrões.

A transcrição na íntegra das falas dos participantes provenientes das discussões foi lida e sintetizada para compor os resultados.

\subsubsection{Terceira etapa:}

A comparação entre os grupos experimental e controle subsidiou a avaliação da ação educativa. Para tanto, a interpretação dos resultados do instrumento IT - HOME foi realizada por meio da aplicação do teste estatístico para medidas repetidas - modelo de 
ANOVA ("Analysis of Variance" - Análise de Variância). Este modelo visa comparar dois grupos ou mais mediante suas médias, tendo como objetivo identificar o quanto da variabilidade dos resultados é devido ao tratamento (oficina pedagógica - variância entre grupos) e o quanto é devido a erro (variância dentro dos grupos).

Para análise da influência das variáveis nos resultados, foi utilizado o Modelo de Efeitos Mistos (LMM), sendo as variáveis consideradas: idade da criança e sua frequência ou não em creche, escolaridade do cuidador primário e classe econômica da família.

O programa estatístico utilizado foi o Statistical Package for the Social Sciences (SPSS) (versão 22).

Os dados relativos às características de cada grupo foram apresentados segundo frequências e percentuais ou por médias e desvios padrões.

\subsection{CONSIDERAÇÕES ÉTICAS}

Em consonância com a Resolução 466 de 2012 do Conselho Nacional de Saúde (Brasil, 2012), que determina as diretrizes e normas regulamentadoras da pesquisa envolvendo seres humanos, este projeto foi aprovado pelo Comitê de Ética em Pesquisa da Escola de Enfermagem da USP, parecer número 952.23 e CAAE 38202814.2.0000.5392, conforme Anexo 3, e autorizado pela Área de Educação em Saúde da Secretaria de Saúde de Sorocaba/SP, conforme Anexo 4, município em que foi realizada a pesquisa.

Após aprovação das instâncias envolvidas, cada participante foi convidado a participar do estudo. Para isso, foi apresentado o objetivo da pesquisa, riscos, benefícios e os procedimentos de coleta de dados, bem como o Termo de Consentimento Livre e Esclarecido (TCLE). Este foi assinado em duas vias, ficando uma em posse do participante e outra em posse do pesquisador.

O anonimato dos participantes foi resguardado, respeitando assim o compromisso ético da pesquisa. 
RESULTADOS 


\section{RESULTADOS}

\subsection{PRIMEIRA ETAPA}

Esta etapa teve como objetivo avaliar a estimulação do desenvolvimento da criança no ambiente doméstico por meio do Inventário IT - HOME, antes da realização da ação educativa. As visitas domiciliares para aplicação desse instrumento foram realizadas durante o período compreendido entre março e junho de 2015, e envolveram a participação de duas pesquisadoras.

Foram realizadas 28 visitas domiciliares, sendo avaliadas 30 relações de cuidado entre cuidador primário e criança, pois em duas residências foram avaliadas duas crianças, sendo o mesmo cuidador. Cada visita durou cerca de 30 a 45 minutos. Não houve recusa de participação, todos os convidados optaram pelo aceite; houve solicitação de alguns usuários do serviço de saúde para inserção no estudo, sendo incluídos por atenderem aos critérios de inclusão.

Além da avaliação pelo Inventário IT - HOME, foram obtidos dados para caracterização do cuidador primário, da criança e da condição econômica da família pelo Critério de Classificação Econômica Brasil - ABEP.

\subsubsection{Caracterização dos cuidadores}

Todos os cuidadores primários eram do sexo feminino, e, quanto à relação com a criança, 96,6\% (29) eram mães e 3,4\% (01) era avó. A idade variou entre 17 e 37 anos.

A caracterização quanto a faixa etária, escolaridade e inserção em atividade remunerada está descrita na Tabela 3. 
Tabela 3 - Caracterização do cuidador primário da criança segundo faixa etária, escolaridade e realização de atividade remunerada $(\mathrm{N}=30)$. Sorocaba, 2015.

\begin{tabular}{lcc}
\hline Faixa etária (anos) & $\mathbf{N}$ & $\%$ \\
$<20$ anos & 06 & 20,0 \\
$20-24$ & 07 & 23,3 \\
$25-29$ & 08 & 26,7 \\
$30-35$ & 07 & 23,3 \\
$>35$ anos & 02 & 6,7 \\
\hline Escolaridade & $\mathbf{N}$ & $\%$ \\
Fundamental I completo & 06 & 20,0 \\
Fundamental II completo & 11 & 36,7 \\
Médio completo & 12 & 40,0 \\
Superior completo & 01 & 3,3 \\
\hline Realização de atividade & & \\
remunerada & & \\
Sim & 06 & 20,0 \\
Não & 24 & 80,0 \\
\hline TOTAL & $\mathbf{3 0}$ & $\mathbf{1 0 0}$
\end{tabular}

Fonte: Dados da Pesquisa, Sorocaba, 2015.

Nota: Dois dados foram repetidos, visto que foram 28 domicílios e 30 relações de cuidado (em duas residências foram avaliadas duas crianças, sendo o mesmo cuidador).

\subsubsection{Caracterização das crianças}

As crianças foram caracterizadas segundo sexo, idade e frequência em creche (Tabela 4). 
Tabela 4 - Caracterização da criança segundo sexo, faixa etária e frequência em creche ( $N=30)$. Sorocaba, 2015.

\begin{tabular}{lcc}
\hline Sexo & $\mathbf{N}$ & $\%$ \\
Feminino & 15 & 50,0 \\
Masculino & 15 & 50,0 \\
\hline Faixa etária (meses) & 09 & \\
$1-4$ & 05 & 30,0 \\
$5-8$ & 04 & 16,7 \\
$9-12$ & 06 & 13,3 \\
$13-16$ & 03 & 20,0 \\
$17-20$ & 03 & 10,0 \\
$21-24$ & & 10,0 \\
\hline Frequenta Creche & 22 & \\
Não & 08 & 73,3 \\
Sim & $\mathbf{3 0}$ & $\mathbf{1 0 0}$ \\
\hline TOTAL & & \\
\hline
\end{tabular}

Fonte: Dados da Pesquisa, Sorocaba, 2015.

\subsubsection{Classificação Econômica}

A classificação econômica das famílias participantes, sintetizada na Tabela 5 , mostrou que a maior parte delas está inserida nas classes C2 e D-E (73,4\%). 
Tabela 5 - Classificação econômica de acordo com 0 Critério ABEP, 2014 ( $N=30)$, Sorocaba, 2015.

\begin{tabular}{lcc}
\hline Classe & $\mathbf{N}$ & $\%$ \\
\hline B2 & 4 & 13,3 \\
C1 & 4 & 13,3 \\
C2 & 9 & 30,0 \\
D - E & 13 & 43,4 \\
\hline TOTAL & $\mathbf{3 0}$ & $\mathbf{1 0 0}$ \\
\hline
\end{tabular}

Fonte: Dados da Pesquisa, 2015.

Nota: Dois dados foram repetidos, visto que foram 28 domicílios e 30 relações de cuidado (em duas residências foram avaliadas duas crianças, sendo o mesmo cuidador).

\subsubsection{Caracterização do ambiente domiciliar pelo Inventário HOME}

A Tabela 6 indica a classificação do ambiente doméstico segundo os níveis de risco para o desenvolvimento, considerando o escore total do Inventário IT-HOME. Observa-se que a maior parte das crianças estudadas teve risco médio ou alto em relação à estimulação para o desenvolvimento em seu ambiente doméstico.

Tabela 6 - Caracterização do ambiente doméstico por meio do Inventário IT- HOME (N=30), Sorocaba, 2015.

\begin{tabular}{lcc}
\hline HOME TOTAL (Níveis de Risco) & $\mathbf{N}$ & $\%$ \\
\hline Baixo & 7 & 23,3 \\
Médio & 17 & 56,7 \\
Alto & 6 & 20,0 \\
\hline TOTAL & $\mathbf{3 0}$ & $\mathbf{1 0 0}$ \\
\hline
\end{tabular}

Fonte: Dados da Pesquisa, Sorocaba, 2015. 
A análise dos resultados obtidos nas subescalas (Tabela 7) possibilita compreender melhor os aspectos envolvidos na avaliação do ambiente doméstico. Observa-se que a maior pontuação de nível alto de estimulação ocorreu na subescala "Responsividade emocional e verbal da mãe" (63,3\%). A subescala que apresentou maior pontuação de nível baixo de estimulação foi a de "Disponibilidade de materiais, brinquedos e jogos apropriados" $(56,7)$, seguida da subescala "Envolvimento materno com a criança" $(50,0 \%)$.

Tabela 7 - Caracterização do ambiente doméstico por meio do Inventário IT- HOME $(\mathrm{N}=30)$, nas respectivas subescalas.

\section{Caracterização de risco do} ambiente

\begin{tabular}{lccc} 
Subescalas de avaliação & Baixo & Médio & Alto \\
(IT- HOME) & $\mathrm{N}(\%)$ & $\mathrm{N}(\%)$ & $\mathrm{N}(\%)$ \\
\hline
\end{tabular}

\begin{tabular}{llll}
\hline Responsividade emocional & $19(63,3)$ & $11(36,7)$ & $0(0,0)$
\end{tabular}
e verbal da mãe

\begin{tabular}{llccc}
\hline $\begin{array}{l}\text { Ausência de punição e } \\
\text { restrição }\end{array}$ & $1(3,3)$ & $29(96,7)$ & $0(0,0)$ \\
\hline $\begin{array}{l}\text { Organização do ambiente } \\
\text { físico e temporal }\end{array}$ & $11(36,7)$ & $15(50,0)$ & $4(13,3)$ \\
\hline $\begin{array}{l}\text { Disponibilidade de } \\
\text { materiais, brinquedos e } \\
\text { jogos apropriados }\end{array}$ & $8(26,7)$ & $5(16,7)$ & $17(56,7)$ \\
\hline $\begin{array}{l}\text { Envolvimento materno com } \\
\text { a criança }\end{array}$ & $8(26,7)$ & $7(23,3)$ & $15(50,0)$ \\
\hline $\begin{array}{l}\text { Oportunidade de variação } \\
\text { na estimulação diária }\end{array}$ & $4(13,3)$ & $23(76,7)$ & $3(10,0)$ \\
\end{tabular}

Fonte: Dados da Pesquisa, Sorocaba, 2015.

A Tabela 8 apresenta os escores com a pontuação média, mínima e máxima, bem como o desvio padrão (DP) e a mediana dos escores obtidos em cada subescala do IT-HOME. Observa-se que apenas na subescala "Ausência de punição e restrição" nenhuma 
família alcançou a pontuação máxima e que houve famílias cuja pontuação foi muito baixa nas subescalas "Organização do ambiente físico e temporal", "Disponibilidade de materiais, brinquedos e jogos apropriados", "Envolvimento materno com a criança" e "Oportunidade de variação na estimulação diária".

Tabela 8 - Medidas de tendência central dos escores de cada subescala do IT-HOME e pontuações mínimas e máximas possíveis $(\mathrm{N}=30)$.

\begin{tabular}{lccccc}
\hline Subescala & Média & DP & Mediana & $\begin{array}{c}\text { Mínimo } \\
\text { (mín } \\
\text { possível) }\end{array}$ & $\begin{array}{c}\text { Máximo } \\
\text { (máx } \\
\text { possível) }\end{array}$ \\
\hline $\begin{array}{l}\text { Responsividade } \\
\text { emocional e verbal } \\
\text { da mãe }\end{array}$ & 9,57 & 0,935 & 10 & $7(0)$ & $11(11)$ \\
$\begin{array}{l}\text { Ausência de } \\
\text { punição e restrição }\end{array}$ & 5,50 & 0,572 & 5 & $5(0)$ & $7(8)$ \\
$\begin{array}{l}\text { Organização do } \\
\text { ambiente físico e } \\
\text { temporal }\end{array}$ & 4,93 & 1,112 & 5 & $2(0)$ & $6(6)$ \\
$\begin{array}{l}\text { Disponibilidade de } \\
\text { materiais, } \\
\text { brinquedos e jogos } \\
\text { apropriados }\end{array}$ & 4,50 & 3,160 & 4 & $0(0)$ & $9(9)$ \\
$\begin{array}{l}\text { Envolvimento } \\
\text { materno com a } \\
\text { criança }\end{array}$ & 3,17 & 1,533 & 2,5 & $0(0)$ & $6(6)$ \\
$\begin{array}{l}\text { Oportunidade de } \\
\text { variação na } \\
\text { estimulação diária }\end{array}$ & 2,67 & 0,994 & 3 & $1(0)$ & $5(5)$ \\
\hline \begin{tabular}{l} 
Escore Total \\
\hline Fone:Dados da Pesquisa
\end{tabular} & $\mathbf{3 0 , 4 0}$ & $\mathbf{6 , 4 7 3}$ & $\mathbf{3 0}$ & $\mathbf{1 9 ( 0 )}$ & $\mathbf{4 0}(\mathbf{4 5})$ \\
\hline
\end{tabular}

Fonte: Dados da Pesquisa, Sorocaba, 2015. 
Os resultados indicaram relação entre a idade da criança e o nível de estimulação do desenvolvimento no ambiente doméstico. A Tabela 9 mostra que, quanto maior a faixa etária da criança, maior foi a estimulação recebida do cuidador primário, e que crianças menores de 6 meses de idade receberam menos estímulos de seus cuidadores, uma vez que essa faixa etária concentrou as crianças com alto risco e não teve crianças classificadas com baixo risco.

Tabela 9- Relação idade da criança $X$ estimulação do desenvolvimento por parte do cuidador primário $(\mathrm{N}=30)$.

\begin{tabular}{lccc}
\hline \multirow{2}{*}{$\begin{array}{l}\text { Grupos por faixa etária } \\
\text { (meses) }\end{array}$} & \multicolumn{3}{c}{ Caracterização de risco do ambiente } \\
\cline { 2 - 4 } & $\mathrm{N}$ & Médio & Alto \\
\hline $1-4$ & 0 & 4 & $\mathrm{~N}$ \\
\hline $5-8$ & 1 & 4 & 5 \\
\hline $9-12$ & 1 & 3 & 0 \\
\hline $13-16$ & 2 & 3 & 1 \\
\hline $17-20$ & 2 & 1 & 0 \\
\hline $21-24$ & 1 & 2 & 0 \\
\hline
\end{tabular}

Fonte: Dados da Pesquisa, Sorocaba, 2015.

Os comentários registrados no Inventário IT- HOME durante as entrevistas complementaram a avaliação da qualidade e quantidade de estimulação do ambiente doméstico. O Quadro 2 sintetiza tais registros. Para isso, as participantes foram identificadas com a letra "P" seguida do número arábico. 
Quadro 2 - Síntese das observações realizadas pelo entrevistador e comentários das cuidadoras.

(continua)

\begin{tabular}{|c|c|c|}
\hline $\begin{array}{l}\text { Identificação } \\
\text { do } \\
\text { Participante }\end{array}$ & $\begin{array}{c}\text { Idade } \\
\text { da } \\
\text { criança } \\
\text { (meses) }\end{array}$ & COMENTÁRIO (S) \\
\hline P1 & 08 & $\begin{array}{l}\text { Criança sempre no colo, ou no sofá. } \\
\text { Assistem muita televisão. Mãe questionou } \\
\text { "será que é ruim ficar muito tempo no } \\
\text { colo?" Disse que deixa no colo como uma } \\
\text { proteção: "no chão pode ficar doente". } \\
\text { Possui livros de escola dos irmãos mais } \\
\text { velhos. Irmã de } 12 \text { anos conta histórias, } \\
\text { as "inventa". }\end{array}$ \\
\hline P2 & 15 & $\begin{array}{l}\text { Estava sentado no chão brincando com } \\
\text { uma vasilha plástica. Tem poucos } \\
\text { brinquedos. }\end{array}$ \\
\hline P3 & 02 & $\begin{array}{l}\text { Mãe refere que brinca só com o mais } \\
\text { velho (que é o neto), justificando que } \\
\text { "bebê não precisa de estímulo". }\end{array}$ \\
\hline P3 & 19 & $\begin{array}{l}\text { Há estímulo por meio da brincadeira, } \\
\text { criança mais velha. Cuidadora é a avó da } \\
\text { criança. }\end{array}$ \\
\hline P4 & 02 & $\begin{array}{l}\text { Moradia com } 1 \text { cômodo, tudo bem } \\
\text { apertado. Não tem brinquedo. }\end{array}$ \\
\hline P5 & 03 & $\begin{array}{l}\text { Mãe é deficiente auditiva, não gosta muito } \\
\text { de usar o aparelho. }\end{array}$ \\
\hline P7 & 11 & $\begin{array}{l}\text { Estava no chão, só de fralda, } \\
\text { brincando. Moradia com precárias } \\
\text { condições de higiene. Mãe não conta } \\
\text { historia, mas canta "parabéns". Gosta de } \\
\text { celular. Se faz birra, pega no colo ou dá o } \\
\text { celular. }\end{array}$ \\
\hline
\end{tabular}


(continuação)

\begin{tabular}{|c|c|c|}
\hline P9 & 21 & $\begin{array}{l}\text { Vários brinquedos espalhados pela casa, } \\
\text { criança brincando com balde com água. } \\
\text { Mãe acha filho muito egoísta, pois não } \\
\text { gosta de dividir. Questiona: "Ele está se } \\
\text { desenvolvendo bem?" }\end{array}$ \\
\hline P10 & 12 & $\begin{array}{l}\text { Casa com dois cômodos, mãe refere que } \\
\text { não tem espaço para deixar andar no } \\
\text { chão. Atualmente o marido está } \\
\text { desempregado, e tem excesso de zelo } \\
\text { com a criança (não deixa andar no chão). } \\
\text { A mãe acha que isso está } \\
\text { "atrapalhando" o desenvolvimento, } \\
\text { pois ela não tem muitas oportunidades } \\
\text { (fez a comparação com o } \\
\text { desenvolvimento de suas outras filhas). }\end{array}$ \\
\hline $\mathrm{P} 11$ & 03 & $\begin{array}{l}\text { Gemelar } 1 \text {, segundo a mãe, é mais ativa e } \\
\text { chora mais quando longe dela, por isso, } \\
\text { se precisa sair sozinha, sempre a leva e } \\
\text { deixa a irmã com alguém. O pai } \\
\text { conversa. }\end{array}$ \\
\hline P11 & 03 & $\begin{array}{l}\text { Gemelar 2, é mais calma, dificilmente sai, } \\
\text { pois acaba ficando aos cuidados de outra } \\
\text { pessoa, já que a irmã chora se ficar longe } \\
\text { da mãe. }\end{array}$ \\
\hline $\mathrm{P} 12$ & 14 & $\begin{array}{l}\text { Mãe refere que não conta histórias, pois a } \\
\text { criança "não para". }\end{array}$ \\
\hline $\mathrm{P} 13$ & 07 & $\begin{array}{l}\text { Mãe refere que "deixa no chão para } \\
\text { estimular", Fez um "móbile" com tecido } \\
\text { (fita) e colocou sobre o berço, pois } \\
\text { percebeu que criança se interessava por } \\
\text { algo acima dela. Conta histórias, tem } 1 \\
\text { livrinho. }\end{array}$ \\
\hline P14 & 16 & Mãe conta histórias, as inventa. \\
\hline P15 & 04 & $\begin{array}{l}\text { Pais desempregados, vivem de Bolsa } \\
\text { Família. }\end{array}$ \\
\hline P17 & 01 & $\begin{array}{l}\text { Ainda não tem brinquedos, referem que } \\
\text { "não precisa, pois é bebê". Quando } \\
\text { começar a ter dentinho vão comprar um } \\
\text { mordedor. "Pai" não biológico conversa e } \\
\text { conta história. }\end{array}$ \\
\hline
\end{tabular}


(continuação)

\begin{tabular}{|c|c|l|}
\hline P19 & 21 & $\begin{array}{l}\text { Durante a entrevista, a mãe brincou com a } \\
\text { criança, abaixou e cantou junto com ela. }\end{array}$ \\
\hline P20 & 13 & $\begin{array}{l}\text { Casa com TV grande, DVD, cercadinho, } \\
\text { brinquedos, cartaz na parede para as } \\
\text { crianças desenharem. Mãe pedagoga. }\end{array}$ \\
\hline P22 & 02 & $\begin{array}{l}\text { Mãe adolescente busca informações para } \\
\text { auxiliar no cuidado do filho. Refere que } \\
\text { "fez uma pesquisa na internet e } \\
\text { encontrou que é bom colocar música } \\
\text { clássica para os bebês ouvirem", desde } \\
\text { então está colocando sempre. Tem só } \\
\text { mordedores, os pendura no carrinho } \\
\text { para fazer de móbile. Não tem livro de } \\
\text { histórias, conta as que sabe. }\end{array}$ \\
\hline P23 & 07 & $\begin{array}{l}\text { Chão da sala com tapete e vários } \\
\text { brinquedos. }\end{array}$ \\
\hline P25 & 17 & $\begin{array}{l}\text { Tem, na sala, um cantinho com } \\
\text { brinquedos. }\end{array}$ \\
\hline P27 & 23 & $\begin{array}{l}\text { Mãe colocou papelão no chão para deixar } \\
\text { a criança brincar sem ficar no chão frio. }\end{array}$ \\
\hline
\end{tabular}

Fonte: Folhas de registro do IT-HOME. Dados da pesquisa.

*Nota: Não foram registrados comentários para o P6, P16, P18, P21, P24, P26 e P28.

Essa etapa contribuiu para o planejamento da ação educativa, visto que as atividades foram elaboradas de acordo com as necessidades identificadas por meio da aplicação do Inventário IT - HOME, ou seja, a identificação dos riscos e os comentários das cuidadoras nortearam a escolha das atividades propostas na ação educativa. 


\subsection{SEGUNDA ETAPA}

A segunda etapa compreendeu a execução das Oficinas Pedagógicas que ocorreram nos meses de junho e julho de 2015. Os 28 cuidadores que compuseram a amostra da primeira etapa foram convidados a participar dos encontros.

Foram realizadas duas Oficinas Pedagógicas, cada uma composta por dois encontros abordando os mesmos assuntos. Tal estratégia foi adotada com 0 intuito de ampliar o número de participantes do Grupo Experimental (GE).

No primeiro encontro da Oficina I, tivemos seis participantes e, no segundo encontro, dois destes faltaram, totalizando quatro participantes.

Já na Oficina II, tivemos cinco participantes no primeiro encontro e, no segundo, dois destes faltaram, totalizando três participantes.

Portanto, houve 11 participantes em pelo menos um dos encontros de cada Oficina Pedagógica, e sete participaram dos dois encontros da oficina.

Também tivemos a participação de outras três pessoas que não compunham a amostra da pesquisa, mas compareceram às atividades educativas espontaneamente. Uma delas participou dos dois encontros de uma Oficina e as outras duas de apenas um dos encontros.

Cada encontro durou entre 60 a 120 minutos, contemplando a execução do cronograma previamente elaborado. Foram duas Oficinas com os mesmos temas, no entanto a maneira de condução desse cronograma foi diferente em cada grupo visando atender às necessidades das participantes.

No convite, foi dada a possibilidade para participantes levarem as crianças aos encontros, pois a maioria não frequentava a creche. 
O espaço lúdico montado para essas crianças contou com a participação de uma voluntária que, durante todo o decorrer dos encontros, desenvolveu atividades de recreação com elas (Figura 3).

Figura 3 - Espaço para recreação montado na ESF Aparecidinha, Sorocaba, 2015.

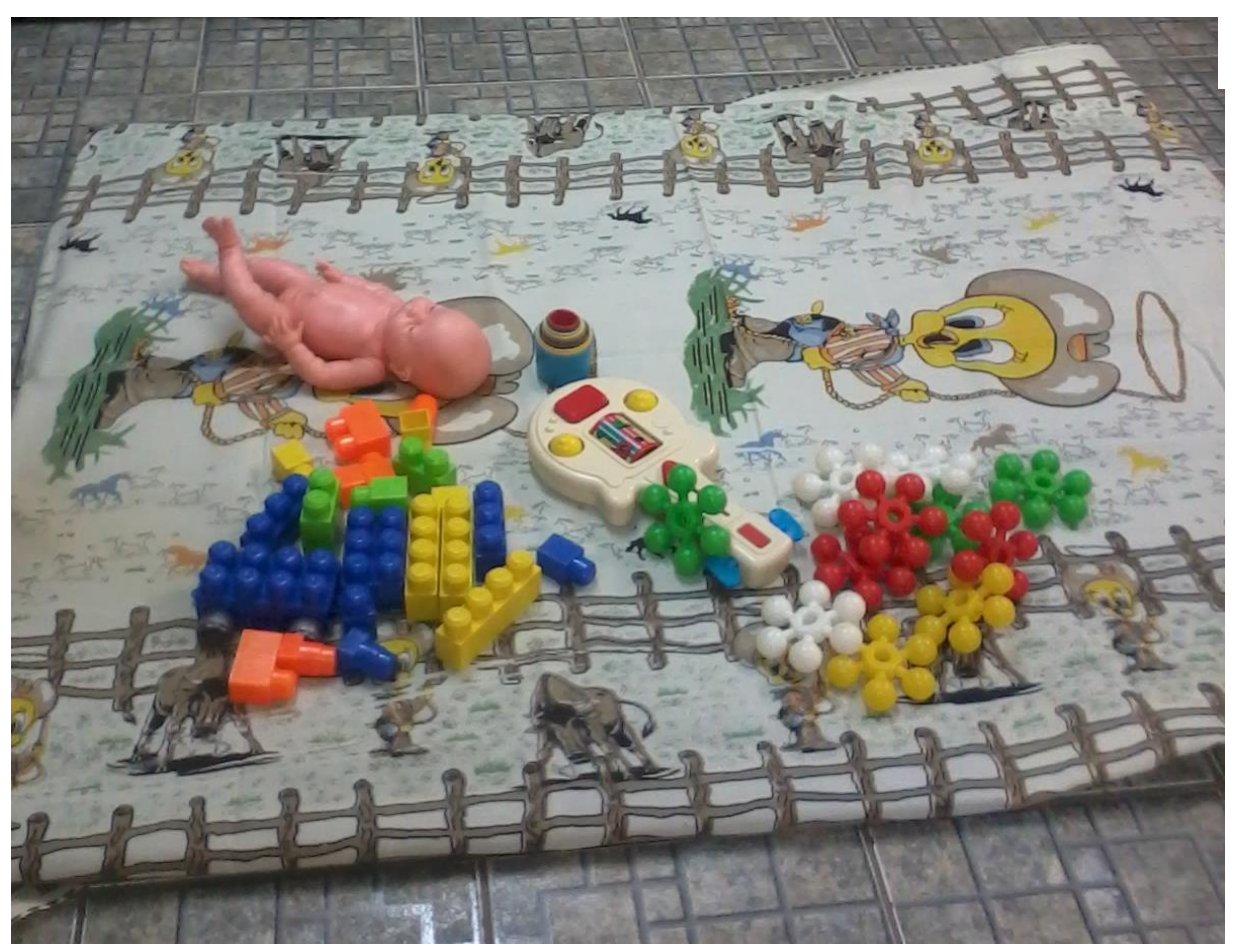

Fonte: Dados da Pesquisa, Sorocaba, 2015.

No andamento das discussões, já aproveitávamos para avaliar aspectos do desenvolvimento das crianças que ali estavam, bem como interagir com elas por meio das brincadeiras.

Durante as discussões, o grupo esclareceu dúvidas, trocou experiências e expôs opiniões e valores. Nos momentos de reflexão, as participantes demonstraram compreensão em relação aos temas abordados, demonstrando interesse pelo assunto.

As discussões foram gravadas e transcritas na íntegra e, algumas delas serão apresentadas aqui com 0 intuito de complementar a apresentação do que foi a realização das Oficinas 
Pedagógicas. A identificação com a letra "P" seguida do número arábico utilizada na aplicação do Inventário IT- HOME foi mantida.

Os diálogos obtidos nas atividades educativas foram organizados em temas para facilitar essa descrição.

No tema APRENDIZADO DAS CRIANÇAS foram elencadas as concepções das participantes acerca do aprendizado infantil bem como meios utilizados por elas para a sua promoção:

P14: Quando ela vai tomar banho eu coloco um brinquedo na banheira.

P22: Eu acho que é mostrando cores, objetos, falar com eles (...) não precisa ter o brinquedo, às vezes usar uma roupa (...) textura.

P15: Ela vê todo mundo pegando o celular e falando assim (...), ai ela pega e coloca na orelha [risos].

Em O BRINCAR ENTRE A CRIANÇA E O ADULTO foi incluída a concepção sobre a importância do brincar entre eles.

P10: Sabendo brincar (...) o adulto sabe mostrar o que é certo, o que é errado.

Outro tema formado foi o do DESENVOLVIMENTO INFANTIL E A IMPOSIÇÃO DOS LIMITES, composto por relatos acerca da compreensão do desenvolvimento da criança e a necessidade de impor limites:

P8: Será que com 8 [meses] já sabe já? [refletindo sobre os limites].

P8: Tem a hora do passeio, com o carrinho (...) que a gente pode pegar um pouquinho no colo, ai chega em casa, quer colo (...) não pode! 
P10: O pai dela (...) ela toma conta dele (...) Para ele, ela não pode chorar (...) Comigo não, eu ignoro, nem ligo, ela é totalmente diferente comigo.

E, em um último tema, estiveram os QUESTIONAMENTOS, entre os quais se incluíram os pedidos por esclarecimentos de dúvidas durante a realização da ação educativa.

P8: E se colocar na televisão será que não distrai? (...) $\mathrm{Na}$ idade dela eu dou o brinquedo e ela joga no chão.

P22: Eu não estou sabendo lidar com essa fase [filho com 4 meses de idade].

No momento de sensibilização das participantes sobre a importância do brincar com seus filhos, houve a produção de um cartaz em cada uma das Oficinas, em que foi registrada a brincadeira que mais gostavam na infância bem como o sentimento que se remetia a ela.

As figuras 4 e 5 retratam os cartazes elaborados:

Figura 4- Cartaz produzido na Oficina Pedagógica I, segundo encontro.

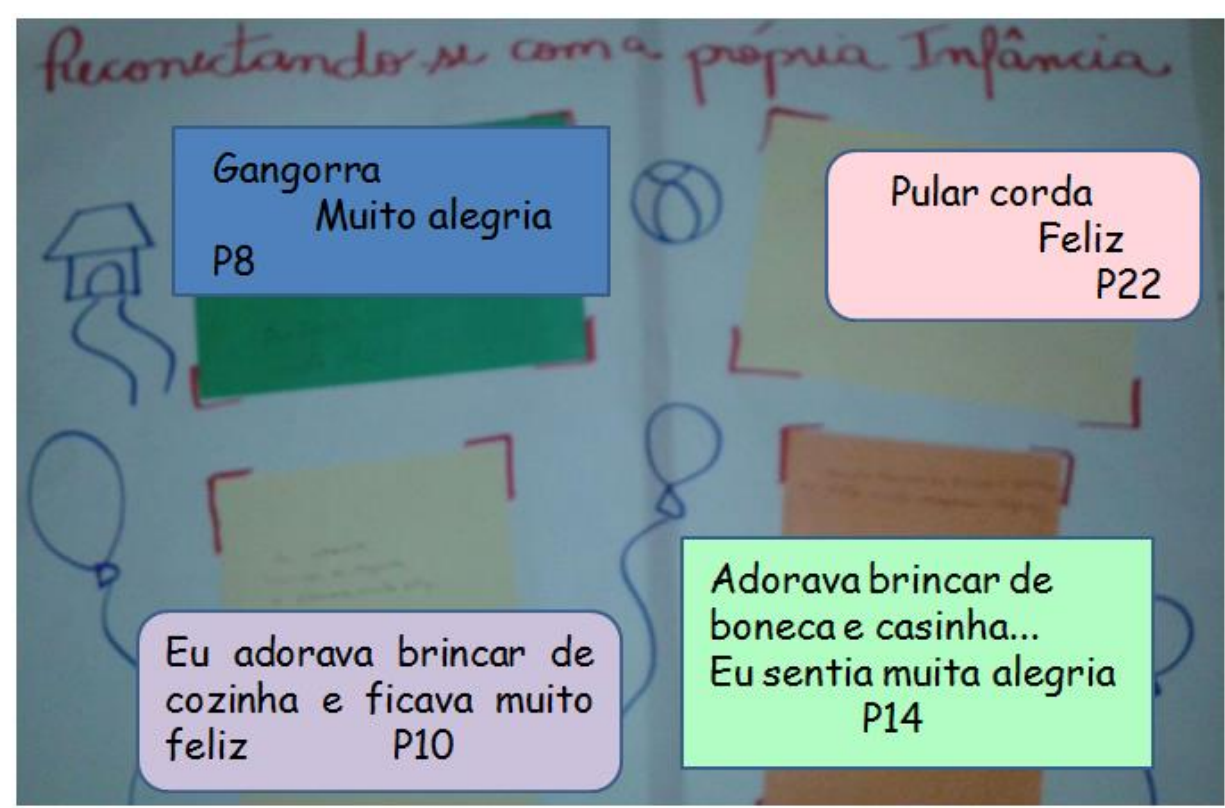

Fonte: Dados da Pesquisa, Sorocaba, 2015. 
Figura 5- Cartaz produzido na Oficina Pedagógica II, segundo encontro.

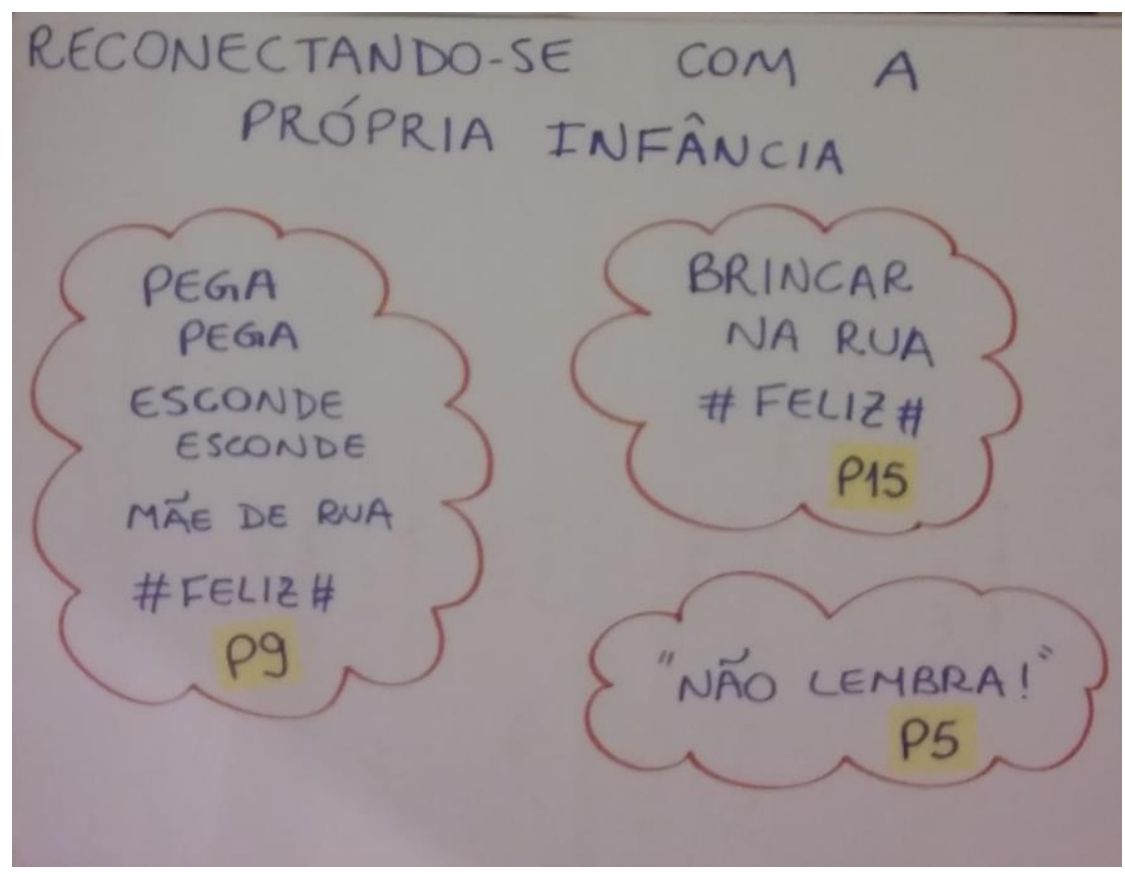

Fonte: Dados da Pesquisa, Sorocaba, 2015.

As Oficinas Pedagógicas foram finalizadas com a discussão norteada pela seguinte questão: "Como foi participar de um encontro que falasse sobre o desenvolvimento da criança?"

Os diálogos realizados foram registrados e as falas das participantes agrupadas de acordo com seus temas principais:

O tema COMPARTILHAR E APRENDER foi destacado como um ponto positivo, que possibilitou a troca de saberes e o fortalecimento do conhecimento:

P10: [...] é bom né? (...) troca a informação (...) fala uma coisa (...) fala outra, uma coisa que você não sabe né? (...), você vai aprendendo né?!

P22: E eu achei legal também não ter uma única idade porque você vai trocando (...), você vê que quem tá lá na frente já passou pelo que você tá passando ou tem alguma coisa pra te (...) uma dica pra te dar "olha" (...); é (...) essa faixa etária 
que vocês colocaram (...), não tá todo mundo na mesma (...), não tá todo mundo passando pela mesma coisa.

As participantes justificaram a importância do compartilhar e aprender pela INFINITUDE DO CONHECIMENTO. Este tema mostrou a compreensão de que o conhecimento sempre está em construção:

P14: A gente nunca sabe tudo né? A gente nunca sabe tudo.

P14: (...) a gente tem tantas dúvidas.

E, por fim, mostraram seu RECONHECIMENTO, nos relatos acerca da satisfação em participar da ação educativa:

P10: Obrigada (...) por esse trabalho que fez com a gente.

P10: É muito bom, né? é bom se tivesse sempre [risos].

$P 8: E ́$ (...) muito (...) e as pessoas viessem, (...) não vem, tem preguiça de vim.

P10: É interessante né?(...), bem legal.

Esses dados revelaram interesse das participantes pela temática abordada bem como pelas dinâmicas de discussão e construção do conhecimento em grupo.

Quanto à avaliação das Oficinas Pedagógicas, a Tabela 10 sintetiza os dados obtidos por meio do questionário aplicado às participantes do segundo encontro em cada uma das oficinas, quanto à caracterização da participante e da criança. 
Tabela 10 - Questionário de Avaliação das Oficinas Pedagógicas Caracterização das participantes e da criança $\left(\mathrm{N}=7^{\star}\right)$.

\begin{tabular}{|c|c|c|c|}
\hline \multirow[b]{2}{*}{ № } & \multicolumn{2}{|c|}{ Caracterização do Cuidador } & \multirow{2}{*}{$\begin{array}{c}\text { Caracterização } \\
\text { da Criança } \\
\text { Idade } \\
\text { (meses) }\end{array}$} \\
\hline & $\begin{array}{l}\text { Idade } \\
\text { (anos) }\end{array}$ & Escolaridade & \\
\hline P10 & 36 & Ensino Fundamental Completo I & 14 \\
\hline P14 & 34 & Ensino Médio Completo & 18 \\
\hline $\mathrm{P} 22$ & 18 & Ensino Médio Completo & 4 \\
\hline P8 & 23 & Ensino Fundamental Completo I & 8 \\
\hline P15 & 21 & Ensino Fundamental Completo II & 4 \\
\hline P5 & 27 & Ensino Fundamental Completo II & 7 \\
\hline P9 & 20 & Ensino Fundamental Completo II & 24 \\
\hline
\end{tabular}

Fonte: Dados da Pesquisa, Sorocaba, 2015.

*Questionário aplicado no segundo encontro de cada Oficina Pedagógica, houve quatro faltas em relação ao primeiro dia, totalizando, portanto, sete participantes.

Observa-se que a maioria das participantes que respondeu à avaliação das atividades educativas tinha Ensino Fundamental II completo e a idade dos seus filhos variou entre 4 e 24 meses.

A Tabela 11 apresenta as respostas relativas à avaliação da ação educativa. Observa-se que a avaliação foi muito positiva quanto à avaliação geral, ao conteúdo, à forma de apresentação e à aplicabilidade do conhecimento obtido no dia a dia com a criança no ambiente doméstico. Quanto à carga horária, as participantes dividiram-se entre considerar muito tempo, tempo adequado e pouco tempo.

Além disso, a maioria não tinha participado de outra atividade com o mesmo tema, mas grande parte já tinha recebido informação sobre como estimular a criança.

Contudo, cabe ressaltar que $57,1 \%$ das participantes que responderam à avaliação afirmaram que não leem/nunca leram as informações da Caderneta de Saúde da Criança e mostraram-se 
interessadas quando estimuladas na oficina a explorar o conteúdo da caderneta.

Tabela 11- Avaliação das Oficinas Pedagógicas pelas participantes.

\begin{tabular}{lcc}
\hline Avaliação Geral & N & $\%$ \\
\hline Ótimo & 05 & 71,4 \\
Bom & 02 & 28,6 \\
\hline Conteúdo & & \\
Ótimo & 04 & 57,1 \\
Bom & 03 & 42,9 \\
\hline Forma de apresentação & & \\
Ótimo & 05 & 71,4 \\
Bom & 01 & 14,3 \\
Ruim & 01 & 14,3 \\
\hline Aplicabilidade & & \\
Sim & 06 & 85,7 \\
Não & 01 & 14,3 \\
\hline Carga horária & & \\
Foi o necessário & 03 & 42,8 \\
Foi muito & 02 & 28,6 \\
Foi pouco & 02 & 28,6 \\
\hline TOTAL & $\mathbf{0 7}$ & $\mathbf{1 0 0}$ \\
\hline
\end{tabular}

Fonte: Dados da Pesquisa, Sorocaba, 2015.

Nos registros complementares oportunizados pelo Questionário, foram encontrados os seguintes comentários:

- Quanto à Avaliação Geral:

P10: Eu gostei muito, pena que durou pouco.

P22: Eu acho que a questão das várias idades ajuda a entender o desenvolvimento. 


\section{- Quanto ao Conteúdo:}

P22: Faltou tempo para abordar todos os conteúdos até os dois anos de idade.

\section{- Quanto à Carga Horária:}

P22: Faltou o tema primeiros socorros.

\section{- Comentários em Geral:}

P10: Bom se a gente puder dar continuidade.

P22: Gostaria que tivesse este curso durante a gestação. Maior tempo para abordar outros temas dentro do desenvolvimento.

Participante gestante que não compunha a amostra: Minha opinião é que, como estou sendo mãe agora, adorei saber como lidar com cada fase da minha filha.

Em relação aos aspectos que facilitaram a execução das Oficinas, estiveram presentes: a aplicação prévia do Inventário IT- HOME, a presença das crianças no espaço lúdico e a dinâmica de desenvolvimento das atividades com a promoção do espaço dialógico.

A aplicação prévia do IT- HOME facilitou a mediação da discussão, pois a pesquisadora conheceu a realidade de cada participante, podendo nortear a busca por estratégias de estimulação da criança no ambiente doméstico de acordo com a realidade de cada um.

A participação das crianças, por sua vez, foi extremamente profícua para o desenvolvimento das atividades, pois muitas das discussões foram incrementadas pela prática.

Já como dificuldades estiveram presentes a falta de tempo para aprofundamento de alguns conteúdos e o número de faltas do 
primeiro para o segundo encontro, o que fez com que o número de participantes nos dois grupos fosse menor do que o previsto no dimensionamento amostral. O mês de realização das Oficinas foi de muita chuva e vento, o que contribuiu para as ausências, visto que o deslocamento das participantes do domicílio para a unidade de saúde se dava caminhando.

Além disso, o pouco contato da autora que conduziu as Oficinas com as participantes, pode ter limitado seus comentários e discussões.

\subsection{TERCEIRA ETAPA}

Esta etapa teve como objetivo reaplicar o Inventário IT - HOME nos participantes do Grupo Experimental (GE) e do Grupo Controle (GC).

O GE foi composto pelos que participaram da Oficina Pedagógica, em pelo menos um encontro, totalizando onze crianças e famílias. Nesta terceira etapa, houve duas perdas, ficando a amostra com nove participantes.

No GC, inicialmente composto por 15 participantes, houve sete perdas, sendo a amostra composta por oito crianças em sete famílias.

Essas perdas foram provenientes da mudança das participantes de bairro ou município, e por não terem sido encontradas no domicílio em pelo menos duas tentativas.

A Tabela 12 indica a caracterização dos cuidadores de cada grupo quanto à faixa etária, escolaridade e exercício em atividade remunerada. Todos os cuidadores primários eram do sexo feminino, e quanto à relação com a criança, todos eram mães. A idade variou entre 18 e 37 anos no grupo experimental, e entre 19 e 34 anos no grupo controle. 
Tabela 12 - Caracterização das cuidadoras dos GE e GC segundo faixa etária, escolaridade e realização de atividade remunerada. Sorocaba, 2015.

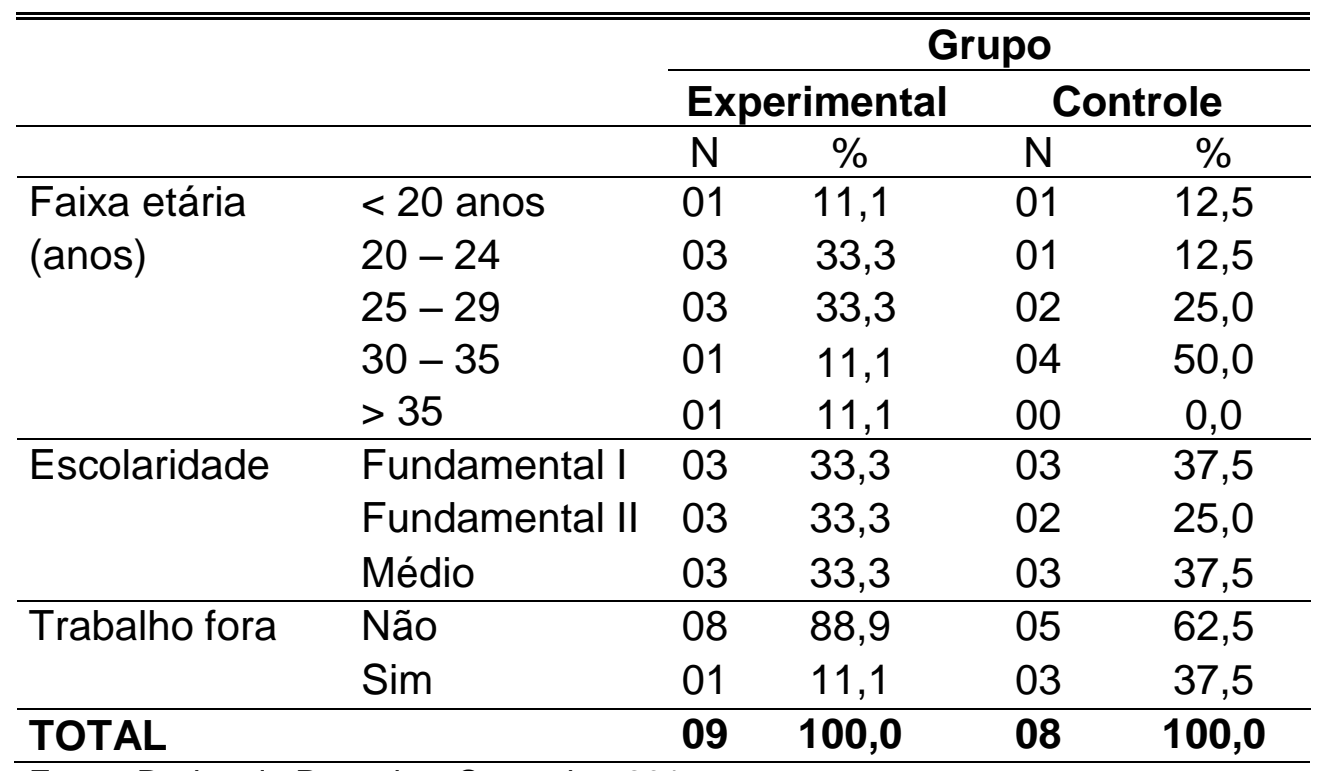

Fonte: Dados da Pesquisa, Sorocaba, 2015.

Nota: Um dado foi repetido, visto que em uma residência foram avaliadas duas crianças, sendo o mesmo cuidador.

A Tabela 13 indica a classificação econômica das famílias segundo o Critério ABEP.

Tabela 13 - Classificação econômica de acordo com o Critério ABEP, 2014. Sorocaba, 2015.

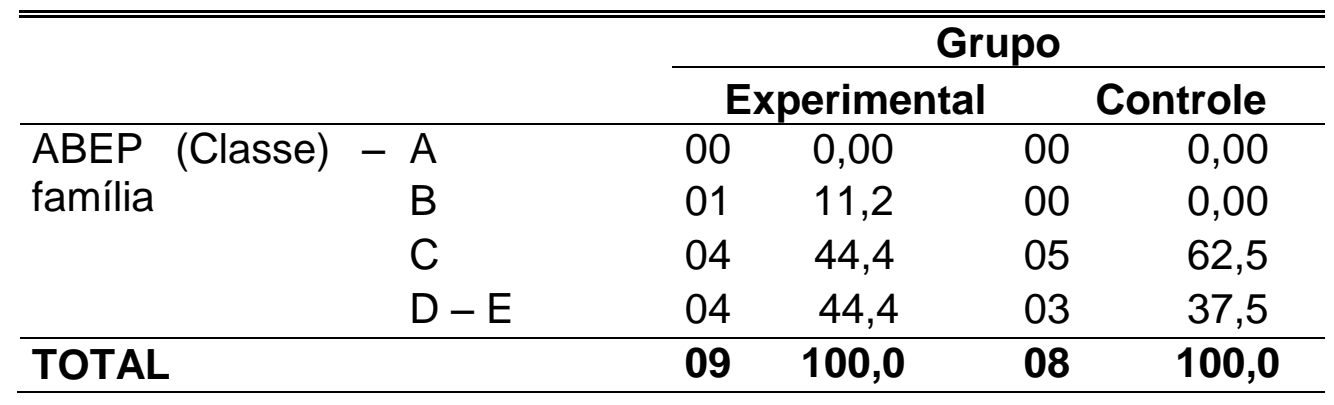

Fonte: Dados da Pesquisa, Sorocaba, 2015.

Nota: Um dado foi repetido, visto que em uma residência foram avaliadas duas crianças, sendo o mesmo cuidador. 
A Tabela 14 indica a caracterização das crianças de cada grupo quanto ao sexo, faixa etária, frequência em creche e a Tabela 15 apresenta a classificação de risco pelo Inventário IT - HOME. A idade variou entre 7 e 26 meses no grupo experimental, e entre 5 e 20 meses no grupo controle.

Tabela 14 - Caracterização das crianças do GE e do GC segundo sexo, faixa etária e frequência em creche.

\begin{tabular}{llcccc}
\hline \hline & & \multicolumn{4}{c}{ Grupo } \\
\cline { 3 - 6 } & & \multicolumn{3}{c}{ Experimental } & Controle \\
\hline Sexo & Masculino & 04 & 44,4 & 05 & 62,5 \\
& Feminino & 05 & 55,6 & 03 & 37,5 \\
\hline Faixa etária & $1-4$ & 00 & 0,0 & 00 & 0,0 \\
(meses) & $5-8$ & 03 & 33,3 & 03 & 37,5 \\
& $9-12$ & 02 & 22,2 & 01 & 12,5 \\
& $13-16$ & 01 & 11,1 & 01 & 12,5 \\
& $17-20$ & 01 & 11,1 & 03 & 37,5 \\
& $21-24$ & 00 & 0,0 & 00 & 0,0 \\
& $>24$ & 02 & 22,2 & 00 & 0,0 \\
\hline Frequenta creche & Não & 07 & 77,8 & 04 & 50,0 \\
& Sim & 02 & 22,2 & 04 & 50,0 \\
\hline TOTAL & & $\mathbf{0 9}$ & $\mathbf{1 0 0 , 0}$ & $\mathbf{0 8}$ & $\mathbf{1 0 0 , 0}$ \\
\hline \hline
\end{tabular}

Fonte: Dados da Pesquisa, Sorocaba, 2015.

Tabela 15 - Caracterização do ambiente doméstico por meio do Inventário IT- HOME. Sorocaba, 2015.

\begin{tabular}{llcccc}
\hline \hline & & \multicolumn{4}{c}{ Grupo } \\
\cline { 3 - 6 } & & $\mathrm{N}$ & $\%$ & $\mathrm{~N}$ & Controle \\
\hline & & 05 & 55,6 & 05 & 62,5 \\
\hline Classificação do & Baixo & 04 & 44,4 & 03 & 37,5 \\
risco - ambiente & Médio & 00 & 0,00 & 00 & 0,00 \\
& Alto & $\mathbf{0 9}$ & $\mathbf{1 0 0 , 0}$ & $\mathbf{0 8}$ & $\mathbf{1 0 0 , 0}$ \\
\hline TOTAL & & & & &
\end{tabular}

Fonte: Dados da Pesquisa, Sorocaba, 2015. 
Observa-se que, em ambos os grupos, os ambientes domiciliares foram classificados em Baixo ou Médio risco para o desenvolvimento infantil.

A Tabela 16 apresenta os dados descritivos e comparativos entre os grupos experimental e controle, interpretados pelo ANOVA - Medidas Repetidas . 
Tabela 16 - Interpretação dos dados pelo modelo ANOVA - Medidas Repetidas, considerando média, DP, mediana e valor- $p$ para coleta e interação.

\begin{tabular}{|c|c|c|c|c|c|c|c|c|c|c|}
\hline & & \multirow[b]{2}{*}{$\mathbf{N}$} & \multicolumn{3}{|c|}{$\begin{array}{c}\text { Primeira avaliação pelo IT- } \\
\text { HOME }\end{array}$} & \multicolumn{3}{|c|}{$\begin{array}{c}\text { Segunda avaliação pelo IT- } \\
\text { HOME }\end{array}$} & \multirow[b]{2}{*}{ Coleta } & \multirow[b]{2}{*}{ Interação } \\
\hline & & & $\begin{array}{l}\text { Média } \\
\text { dos } \\
\text { escores } \\
\text { obtidos }\end{array}$ & DP & Mediana & $\begin{array}{l}\text { Média } \\
\text { dos } \\
\text { escores } \\
\text { obtidos }\end{array}$ & DP & Mediana & & \\
\hline HOME Subescala I & $\begin{array}{l}\text { Experimental } \\
\text { Controle }\end{array}$ & $\begin{array}{l}9 \\
8\end{array}$ & $\begin{array}{l}9,33 \\
9,50\end{array}$ & $\begin{array}{l}1,225 \\
0,756\end{array}$ & $\begin{array}{c}9,00 \\
10,00\end{array}$ & $\begin{array}{l}10,00 \\
10,75\end{array}$ & $\begin{array}{l}1,732 \\
0,463\end{array}$ & $\begin{array}{l}11,00 \\
11,00\end{array}$ & 0,002 & 0,284 \\
\hline HOME Subescala II & $\begin{array}{l}\text { Experimental } \\
\text { Controle }\end{array}$ & $\begin{array}{l}9 \\
8\end{array}$ & $\begin{array}{l}5,56 \\
5,75\end{array}$ & $\begin{array}{l}0,527 \\
0,707\end{array}$ & $\begin{array}{l}6,00 \\
6,00\end{array}$ & $\begin{array}{l}5,33 \\
5,63\end{array}$ & $\begin{array}{l}0,500 \\
0,744\end{array}$ & $\begin{array}{l}5,00 \\
5,50\end{array}$ & 0,405 & 0,814 \\
\hline HOME Subescala III & $\begin{array}{l}\text { Experimental } \\
\text { Controle }\end{array}$ & $\begin{array}{l}9 \\
8\end{array}$ & $\begin{array}{l}5,11 \\
4,63\end{array}$ & $\begin{array}{l}0,782 \\
1,188\end{array}$ & $\begin{array}{l}5,00 \\
5,00\end{array}$ & $\begin{array}{l}6,00 \\
5,88\end{array}$ & $\begin{array}{l}0,000 \\
0,354\end{array}$ & $\begin{array}{l}6,00 \\
6,00\end{array}$ & $<0,001$ & 0,460 \\
\hline HOME Subescala IV & $\begin{array}{l}\text { Experimental } \\
\text { Controle }\end{array}$ & $\begin{array}{l}9 \\
8\end{array}$ & $\begin{array}{l}4,22 \\
4,75\end{array}$ & $\begin{array}{l}2,906 \\
3,327\end{array}$ & $\begin{array}{l}3,00 \\
5,50\end{array}$ & $\begin{array}{l}5,22 \\
6,75\end{array}$ & $\begin{array}{l}1,202 \\
1,165\end{array}$ & $\begin{array}{l}5,00 \\
6,00\end{array}$ & 0,041 & 0,467 \\
\hline HOME Subescala V & $\begin{array}{l}\text { Experimental } \\
\text { Controle }\end{array}$ & $\begin{array}{l}9 \\
8\end{array}$ & $\begin{array}{l}3,44 \\
3,00\end{array}$ & $\begin{array}{l}1,424 \\
1,414\end{array}$ & $\begin{array}{l}3,00 \\
2,00\end{array}$ & $\begin{array}{l}4,78 \\
5,38\end{array}$ & $\begin{array}{l}1,563 \\
0,744\end{array}$ & $\begin{array}{l}6,00 \\
5,50\end{array}$ & $<0,001$ & 0,208 \\
\hline HOME Subescala VI & $\begin{array}{l}\text { Experimental } \\
\text { Controle }\end{array}$ & $\begin{array}{l}9 \\
8\end{array}$ & $\begin{array}{l}2,89 \\
2,75\end{array}$ & $\begin{array}{l}1,167 \\
1,035\end{array}$ & $\begin{array}{l}3,00 \\
2,50\end{array}$ & $\begin{array}{l}4,00 \\
3,88\end{array}$ & $\begin{array}{l}1,000 \\
0,835\end{array}$ & $\begin{array}{l}4,00 \\
4,00\end{array}$ & 0,002 & 0,981 \\
\hline $\begin{array}{l}\text { HOME Escore } \\
\text { Total }\end{array}$ & $\begin{array}{l}\text { Experimental } \\
\text { Controle }\end{array}$ & $\begin{array}{l}9 \\
8\end{array}$ & $\begin{array}{l}30,78 \\
30,38\end{array}$ & $\begin{array}{l}6,078 \\
5,975\end{array}$ & $\begin{array}{l}29,00 \\
30,50\end{array}$ & $\begin{array}{l}35,33 \\
38,25\end{array}$ & $\begin{array}{l}5,431 \\
2,053\end{array}$ & $\begin{array}{l}38,00 \\
38,50\end{array}$ & 0,001 & 0,261 \\
\hline
\end{tabular}

Fonte: Dados da Pesquisa, Sorocaba, 2015. 
O valor- $p$ traz a análise dos componentes "Coleta" e "Interação".

$\mathrm{Na}$ interação, foram avaliados os escores obtidos no pré e no pós-ação educativa dentro de cada grupo, buscando identificar se a evolução nos valores dos grupos experimental e controle poderia ser considerada igual ou não. Neste caso, nenhuma das variáveis analisadas teve interação significativa, isto é, a evolução nos valores dos escores foi similar em ambos.

O valor- $p$ coleta, por sua vez, que analisa se houve diferença da primeira para a segunda coleta, independente do grupo, indicou que todas as variáveis apresentaram mudança de média do pré para o pós-ação educativa, exceto a subescala II do HOME, referente à "Ausência de Punição e Restrição".

Esses dados indicaram mudança de comportamento nos dois grupos, GE e GC, de forma uniforme, com aumento significativo nas pontuações de ambos, o que representa aumento no nível de estimulação no ambiente doméstico.

Durante esta etapa da coleta de dados, alguns comentários foram registrados, complementado as informações referentes à estimulação da criança, conforme disposto no Quadro 3.

Quadro 3 - Síntese das observações realizadas pelo entrevistador e comentários das cuidadoras.

(continua)

\begin{tabular}{|c|c|c|c|}
\hline $\begin{array}{c}\text { Identificação } \\
\text { da }\end{array}$ & $\begin{array}{c}\text { Idade } \\
\text { da } \\
\text { criança } \\
\text { (meses) }\end{array}$ & Grupo & \multicolumn{1}{|c|}{ COMENTÁRIO (S) } \\
\hline P8 & 10 & GE & $\begin{array}{l}\text { Referiu que comprou um livro de } \\
\text { histórias, mas ainda não o lê, } \\
\text { somente folheia com a criança. }\end{array}$ \\
\hline
\end{tabular}


(continuação)

\begin{tabular}{|l|l|l|l|}
\hline P9 & 25 & GE & $\begin{array}{l}\text { Referiu que passou a conversar } \\
\text { com a criança depois da } \\
\text { "palestrinha", porque antes não } \\
\text { tinha paciência. }\end{array}$ \\
\hline P14 & 20 & GE & $\begin{array}{l}\text { Criança recebeu seu primeiro } \\
\text { exemplar da Bíblia infantil, com } \\
\text { figuras. Mãe começou a ler para } \\
\text { a criança. }\end{array}$ \\
\hline P11 & 07 & GE & $\begin{array}{l}\text { Referiu que após a "palestra" } \\
\text { começou a nomear objetos para } \\
\text { a criança. }\end{array}$ \\
\hline Ge & Gemelar - Mãe referiu que \\
começou a ler histórias para as \\
crianças antes de dormir, o que \\
não fazia antes. Acredita que \\
agora seja adequado para a \\
idade.
\end{tabular}

Fonte: Folhas de registro do IT- HOME. Dados da pesquisa, 2015.

Observa-se no Quadro 3 que houve menor número de registros em relação à primeira aplicação, possivelmente por se tratar de um segundo contato e pela aplicação do IT - HOME ter sido realizada por uma só pesquisadora.

Em relação à influência das variáveis de caracterização das famílias, a escolaridade e a classificação econômica, o Modelo de Efeitos Mistos (LMM), mostrou efeito sobre a subescala IV (Disponibilidade de materiais, brinquedos e jogos apropriados), com valor $p$ igual a 0,005 e 0,003, respectivamente.

Para as famílias da Classe B, o escore total do HOME foi maior em relação às classes $C, D$ e $E$ (valor p igual a 0,011), ou seja, classes econômicas mais baixas foram classificadas com maior risco. 
Quanto aos aspectos relacionados às crianças, identificou-se que a idade foi o fator que teve influência nos resultados no escore total do HOME e de cada subescala, exceto na subescala II "Ausência de Restrição e Punição". À medida que aumentou a idade, os escores do HOME aumentaram, comprovando que a estimulação é maior para as crianças maiores (valor $p$ igual a 0,000). A frequência à creche também foi associada a maiores escores (valor $p$ igual a 0,031). 
DISCUSSÃO 


\section{DISCUSSÃO}

Este estudo investigou o efeito da ação educativa no comportamento dos cuidadores de lactentes sobre a estimulação do desenvolvimento com base em avaliações antes e após a ação educativa com grupos experimental e controle.

Houve aumento de comportamentos de estimulação de desenvolvimento por parte dos cuidadores nos dois grupos, independente da ação educativa, ou seja, os resultados da avaliação do nível de estimulação no ambiente doméstico não mostraram diferença entre os grupos experimental e controle.

No entanto o efeito da Oficina Pedagógica pode ser evidenciado pelos comentários das participantes, visto que estas indicaram a importância em participar de uma atividade de educação em saúde com a temática do desenvolvimento infantil e sua estimulação pela brincadeira.

Os relatos foram positivos e demonstraram que a estratégia foi vista como um potencial de aprendizado, de troca de saberes, experiências e reflexões. A participação voluntária de parentes e amigos também revelou o interesse pelo assunto.

Com isso, esses dois aspectos são o foco desta discussão.

Nos aspectos relativos à mudança de comportamento mensurada pelo IT - HOME, na primeira aplicação observou-se que houve famílias que tiveram pontuação muito baixa nas subescalas "Organização do ambiente físico e temporal", "Disponibilidade de materiais, brinquedos e jogos apropriados", "Envolvimento materno com a criança" e "Oportunidade de variação na estimulação diária". Após a ação educativa e a reavaliação das famílias, essas subescalas apresentaram aumento significativo no nível de estimulação, indicando mudança no comportamento das cuidadoras primárias nos dois grupos.

A influência da condição econômica da família e o nível de escolaridade do cuidador primário no nível de estimulação de 
desenvolvimento proporcionada à criança, esteve em consonância com outros estudos (Andrade et al., 2005; Lamy Filho et al., 2011; Martins, et al., 2004).

Entretanto, o ganho de idade da criança foi o fator de maior impacto para a mudança desse comportamento. Na segunda fase, elas interagiram mais com seus filhos, estimulando-os por meio da brincadeira e do fortalecimento das interações.

O comentário de uma mãe do grupo controle evidencia esse achado, na medida em que justificou o início da leitura às crianças por ser apropriado à idade, o que anteriormente não considerava ser.

Antes da ação educativa, a maior parte das cuidadoras não exercia atividade remunerada, e a maioria das crianças não frequentava creche, portanto, cuidador primário e criança passavam a maior parte do tempo juntos no ambiente doméstico, entretanto, as atividades de interação só aumentaram à medida que a criança ficou mais velha, independente do tempo dispensado para essa interação.

Os próprios comentários das cuidadoras registrados por meio do IT - HOME trouxeram à luz esses conceitos de que crianças muito pequenas não precisavam de estímulos.

Anteriormente a Oficina, a não oferta de oportunidades de estimulação foi justificada como um fator protetor na compreensão da cuidadora quando, por exemplo, o "ficar no chão" foi tido como sinal de cuidado inadequado para o bebê, pois o mesmo poderia adoecer.

Ainda nesse período, as condições do contexto apareceram como influenciadoras do processo de estimulação, impactando de forma negativa nos casos de ambientes muito pequenos, com poucos espaços e com baixa disponibilidade de materiais e brinquedos para as crianças.

Por outro lado, algumas cuidadoras encontraram, nos mesmos contextos, recursos para promoção do desenvolvimento da criança, como confeccionar um móbile com material disponível 
(retalho de tecido), colocar papelão no chão para que a criança pudesse brincar e não ficasse no chão frio, oferecer materiais que não são propriamente um brinquedo, mas que se transformam a partir da criatividade da criança, dentre outras possibilidades, demonstrando a capacidade humana de buscar recursos dentro da sua realidade para atender suas necessidades.

A correlação com experiências passadas também foi apontada. Por mais que se considere que cada desenvolvimento é único e não se pode compará-lo entre as crianças, a busca por experiências vivenciadas anteriormente para identificar possíveis alterações no desenvolvimento da criança atual se fez presente, como por exemplo, a mãe que percebeu que a filha estava demorando mais para andar por conta da falta de oportunidade, sendo que as filhas mais velhas tiveram mais oportunidades e na idade dela já andavam.

Esses apontamentos, juntamente com os dados quantitativos do IT - HOME, conduziram a elaboração das atividades da ação educativa, visto que esta partiu das lacunas de conhecimentos existentes nessas famílias. Esses achados evidenciaram a importância e necessidade do fortalecimento de conhecimentos acerca do desenvolvimento infantil e seus meios de estimulação, tendo a brincadeira como recurso promotor desse processo.

Com isso, a construção da Oficina Pedagógica envolveu planejamento atento e contextualizado às reais demandas da população envolvida. Andrade et al. (2005) apontam que a orientação para o desenvolvimento de atividades lúdicas direcionadas à relação mãe-filho ou cuidador-criança pode ser acolhida no âmbito do ESF, sendo que esta dispõe de potencial para intervir no ambiente familiar.

De maneira complementar, as necessidades sentidas pelos usuários podem ser trabalhadas pelos profissionais de forma a resolver suas reais exigências de saúde (Coelho, Jorge, 2009). 
Após essa etapa de conhecimento da realidade da população, a Oficina Pedagógica foi planejada tendo como meta principal o empoderamento das famílias, a troca de saberes e fortalecimento da autonomia e da capacidade criadora de cada um, considerando que ensinar não é transferir conhecimento, mas criar as possibilidades para a sua produção ou construção, pressupondo a presença de indivíduos que, juntos, trocam experiências de novas informações adquiridas (Freire, 1996).

O envolvimento das participantes nas atividades da oficina, bem como suas avaliações, mostraram os aspectos percebidos como contribuintes para o aprendizado: a participação de cuidadoras com crianças entre várias idades foi um deles, pois o contato com mães que já tinham passado por determinada fase de desenvolvimento corroborou para o aprendizado das mães que tinham os bebês mais novos; outros fatores que contribuíram foram a utilização de metodologias participativas com abordagens individuais e em grupos, o acolhimento e sensibilização das participantes sobre a importância do tema, os procedimentos expositivos dialogados e o respeito aos saberes prévios de cada participante.

O respeito e a valorização do saber de cada um permitiu a relação dialógica. O diálogo não existe se não há humildade, sendo impossível dialogar estando fechado à contribuição dos outros (Freire, 2014). Ainda que o profissional de saúde tenha um conhecimento de bases científicas, não deve se colocar na posição de superioridade, como sendo aquele que ensina, mas sim na posição humilde daquele que comunica um saber relativo aos outros que possuem outro saber relativo (Freire, 2007).

A estratégia pedagógica baseada na dinâmica de grupo permitiu que todos se tornassem sujeitos do processo, e isso se tornou nítido pelas dicas de estimulação que as mães trocaram entre si, sendo a pesquisadora a condutora do processo ditado pelas próprias participantes. 
Esses resultados são similares a outros estudos que utilizaram oficina educativa (Lazzarotto et al., 2013; Lacerda et al., 2003). Nesse formato de ação educativa, os usuários se reconhecem como sujeitos da própria educação, considerando o profissional como um facilitador do processo educativo, o que é muito importante para o entendimento do seu papel na transformação da realidade (Figueiredo, Neto, Leite, 2012), pois tais grupos são espaços nos quais os usuários conseguem expressar suas falas, atingindo uma dinâmica de discussão em torno de seus desejos e anseios (Lacerda, Santiago, 2007).

Assim, o espaço dialógico possibilitado pelas oficinas permitiu a interação entre o grupo, a expressão de vivências e a desmistificação de ideias e conceitos, tal como em outros estudos (Mendonça et al., 2013; Lacerda et al., 2013).

A concepção de que o conhecimento não acaba por ali, demonstra o potencial de alcance da ação educativa no sentido de mobilizar essas cuidadoras para novos interesses. Essa reflexão sobre si mesmo as coloca na busca constante de ser mais, descobrindo-se como ser inacabado (Freire, 2007), garantindo assim a continuidade do processo de aprendizagem.

Outro fator que contribuiu para a construção do conhecimento foi a presença das crianças no espaço lúdico durante o decorrer das atividades, pois aspectos do desenvolvimento infantil, bem como meios de estimulação, já eram realizados nas próprias crianças, permitindo a interação e a correlação da discussão do conteúdo teórico com a prática.

A aplicação prévia do IT - HOME promoveu no grupo a possibilidade de discutir e buscar alternativas dentro do contexto de cada um, o que alicerçou o processo de construção do conhecimento.

Observou-se que o pensar conjuntamente sobre a própria realidade estimulou a consciência reflexiva e a proposição de ações que poderiam ser realizadas nos domicílios. Elas se questionaram a 
respeito de medidas que adotavam, por entender como protetoras, como é o caso de não deixar a criança no chão, e formas de oferecer alternativas mais estimulantes para a criança. Quando o homem compreende a sua realidade, pode levantar hipóteses sobre o desafio dessa realidade e procurar soluções (Freire, 2007), sendo que este foi o principal objetivo da ação educativa: o despertar nos participantes pela busca de estratégias dentro de suas realidades, sem a prescrição de cuidados de forma impositiva ditada pelos profissionais.

A exclusão dos aspectos relacionados à realidade do indivíduo ou comunidade no processo educativo, pode prejudicar a reflexão sobre a realidade vivenciada, não oportunizando aos indivíduos a percepção e expressão dos principais determinantes de uma dada situação na qual estão envolvidos (Flish et al., 2014).

As participantes demonstraram a apreensão de novos conhecimentos, aplicando-os em suas propostas de cuidados às crianças, na medida em que, no dia a dia, incorporaram comportamentos de estimulação do desenvolvimento de seus filhos.

É válido pontuar ainda o relato de uma gestante, cuja participação na Oficina foi voluntária, sobre a importância de saber como lidar com cada fase do desenvolvimento do seu bebê indicando a necessidade de abordar essa temática antes mesmo do nascimento da criança. Esse achado se complementa com o comentário de outra participante quando esta expõe o desejo pela Oficina durante a gestação.

Com isso, infere-se aqui a relevância do tema abordado, bem como o efeito positivo da Oficina enquanto estratégia de educação em saúde, pois desenvolvimento de uma atividade de baixo custo para construção do conhecimento se mostrou eficiente no empoderamento das cuidadoras.

Quanto às dificuldades para a execução das oficinas, estas referiram-se particularmente a questões de organização do tempo e dos períodos disponíveis para a atividade. 
Além disso, o grupo experimental foi composto pela maioria de cuidadoras que não trabalhava fora. A disponibilização de outras datas, com o intuito de ampliar o GE, não envolveu a oferta de outros horários, o que pode ter contribuído para a não participação daquelas que trabalhavam, visto que o horário e dia da semana foram disponibilizados conforme rotina da ESF.

Estudo identificou que a falta de padronização de horário foi um fator dificultador para a participação do usuário nas sessões educativas, relacionado às atribuições dos profissionais de saúde, pois estes as realizavam em horários mais apropriados para eles, sem considerar as necessidades dos usuários (Figueiredo, Neto, Leite, 2012).

A atividade educativa deve considerar a realidade e 0 cotidiano dos participantes, pois não há um compromisso autêntico com a comunidade, se o profissional considera a realidade como algo estático e imutável, não a enxergando como uma totalidade, cujas partes se encontram em permanente interação (Freire, 2007).

Em relação às limitações que estiveram presentes nesta pesquisa, é possível que o próprio instrumento proposto para mensurar o alcance do objetivo não tenha sido suficiente ou adequado.

O IT - HOME, mesmo validado e amplamente usado, pode não ter dado conta de avaliar todas as dimensões de apreensão de conhecimentos contempladas por esta pesquisa.

Por exemplo, o instrumento avalia se a criança possuía três livros ou mais. Após a ação educativa, houve família que adquiriu um livro, por reconhecer essa importância, no entanto, sua pontuação não foi passível de mudança no escore, visto que o instrumento preconiza determinada quantidade. Ainda que a criança estivesse inserida na classificação maior de risco, observou-se a intenção de mudança por parte do cuidador, bem como a busca pela melhoria da qualidade da estimulação proporcionada. 
O olhar individual de cada item do instrumento permite observar essa mudança de comportamento, embora esta não tivesse sido suficiente para garantir a mudança de classificação de um nível de risco para outro mais baixo.

Por isso, a leitura dessas interfaces se faz importante, pois abarcam aspectos que não puderam ser mensurados.

Quanto aos relatos das participantes, não foi possível realizar uma análise qualitativa dada à quantidade e nível de profundidade dos mesmos. Apesar das estratégias utilizadas, o grupo mostrou-se tímido durante as discussões. O que pode ter corroborado para isso foi o fato da pesquisadora que conduziu as oficinas não ser a enfermeira de referência das participantes, tendo apenas um contato anterior, durante a aplicação do IT-HOME.

Um aspecto que não foi possível contrastar refere-se ao tamanho do grupo educativo. Em ambas as oficinas, os grupos formados foram pequenos, menores do que o previsto no método. Esse baixo número configura uma limitação para a pesquisa sendo necessária a ampliação para grupos maiores. Também se faz necessário o desenvolvimento da pesquisa em outros locais para confirmação dos achados.

Salienta-se ainda o fato de que os estudos que identificaram o efeito positivo na mudança de comportamento dos participantes após ações educativas não realizaram a análise de grupo controle, dificultando a comparação com o resultado deste estudo.

Quanto às implicações desta pesquisa para a atuação do enfermeiro, os resultados acerca das avaliações da oficina mostrando a valorização do tema, aliados aos resultados sobre a qualidade de estimulação domiciliar dos lactentes, apontam para a necessidade dos profissionais de saúde incorporarem esses conteúdos nas práticas de cuidado.

A Caderneta de Saúde da Criança mostrou-se de pouco uso por parte das participantes, sendo um instrumento rico e acessível, devendo ser valorizado e seu uso incentivado pelos profissionais. 
A relação do nível de estimulação do desenvolvimento com a idade, aponta ainda para a necessidade e importância de se trabalhar com as ações educativas com essa temática desde o prénatal, tendo em vista o impacto da estimulação nos primeiros anos de vida da criança. 


\section{CONSIDERAÇÕES FINAIS}




\section{CONSIDERAÇÕES FINAIS}

Considerando os objetivos inicialmente propostos, entende-se que os mesmos foram alcançados.

O efeito da ação educativa foi mensurado por meio do Inventário IT-HOME, aplicado em dois momentos, antes e após a realização da Oficina Pedagógica.

Os resultados provenientes da análise do IT-HOME demonstraram que houve aumento de comportamentos de estimulação do desenvolvimento por parte dos cuidadores nos dois grupos, independente da ação educativa.

No entanto, o fato de não ter havido diferença entre os grupos experimental e controle, ou seja, ambos os grupos terem apresentado aumento no nível de estimulação, não invalida a pesquisa, pelo contrário, aponta para outras demandas que envolvem a reorientação da prática de assistência do enfermeiro.

Essa demanda foi expressa pela determinação da idade da criança no nível de estimulação recebida por parte do cuidador primário. Os resultados demonstraram que as crianças maiores foram mais estimuladas e que a variável idade teve maior impacto no nível de estimulação do que a ação educativa.

Sabe-se que a estimulação deve ocorrer mais precocemente possível para favorecer o desenvolvimento infantil, por isso, sugerese que as ações educativas com a temática da estimulação do desenvolvimento infantil sejam desenvolvidas desde o pré-natal.

A ação em saúde deve ser planejada com base nas reais necessidades dos participantes. A avaliação do ambiente doméstico por meio do Inventário IT-HOME permitiu identificar os níveis de risco relacionados à estimulação da criança por parte do cuidador primário. A identificação de que a maioria das famílias encontrava-se classificada em alto e médio risco, incitou a necessidade da realização de ações capazes de despertar nessas famílias a 
importância da estimulação do desenvolvimento infantil por meio de suas próprias ações de cuidados diários.

Para isso, a ação educativa foi elaborada e planejada a partir das lacunas existentes, demonstrando impacto positivo na aceitação das participantes.

Neste estudo, a estratégia de educação em saúde favorecida por meio da Oficina Pedagógica, mostrou-se eficiente; a partir dos relatos das participantes foi possível compreender que a estratégia e a dinâmica foram bem aceitas. $O$ resultado positivo aliado ao baixo custo para sua realização potencializa seu uso enquanto ferramenta de trabalho.

Em relação ao instrumento utilizado, o Inventário IT-HOME, é possível dizer que o mesmo foi pertinente, no entanto pode não ter dado conta de avaliar todas as dimensões do comportamento envolvidas neste estudo.

Além disso, o limitado número de participantes em cada grupo pode não ter sido suficiente para expressão do impacto.

Cabe, portanto a ampliação para grupos maiores, para melhor avaliação desse impacto e que os profissionais se apropriem, em suas práticas de assistência, de ações simples, porém com grande potencial de alcance. 
REFERÊNCIAS 


\section{REFERÊNCIAS}

Andrade AS, Santos DN, Bastos AC, Pedromônico M, Almeida-Filho $\mathrm{N}$, Barreto ML. Ambiente familiar e desenvolvimento cognitivo infantil: uma abordagem epidemiológica. Rev. Saúde Pública. 2005; 39 (4): $606-11$.

Associação Brasileira de Empresas de Pesquisa. Critério de classificação econômica Brasil. [Internet]. Brasília; 2012. Disponível em: <http://www.abep.org/novo/Content.aspx?ContentID=139>.

Brasil. Ministério da Saúde. Agenda de Compromissos para a Saúde Integral da Criança e Redução da Mortalidade Infantil. Brasília: Ministério da Saúde; 2004.

Brasil. Ministério da Saúde (MS). Caderneta de Saúde da Criança. 8 ed. Brasília: Ministério da Saúde; 2013.

Brasil. Ministério da Saúde (MS). Secretaria de Gestão Estratégica e Participativa. Política Nacional de Educação Popular em Saúde. Brasília: MS; 2012.

Brasil. Ministério da Saúde (MS). Secretaria de Gestão do Trabalho e da Educação na Saúde. Departamento de Gestão e da Regulação do Trabalho em Saúde. Câmara de Regulação do Trabalho em Saúde. Brasília: MS; 2006.

Brasil. Senado. Resolução 466 de 12 de dezembro de 2012. Dispõe sobre as normas e diretrizes regulamentadoras de pesquisa envolvendo seres humanos. Brasília. D.O.U., 2012.

Brazelton TB, Greenspan SI. As necessidades essenciais das crianças: o que toda criança precisa para crescer, aprender e se desenvolver. Porto Alegre: Artmed; 2002.

Bustamante V, Trad LAB. Cuidando da saúde de crianças pequenas no contexto familiar: um estudo etnográfico com famílias de camadas populares. Ciênc. Saúde Coletiva. 2007 Set-Out; 12 (5): $1175-84$.

Caldwell BM, Bradley RH. Home Observation for Measurement of the Environment: Administration Manual. Little Rock: University of Arkansas at Little Rock; 2001.

Chiesa AM, Veríssimo MLOR. A educação em saúde na prática do PSF. In: Brasil. Instituto para o Desenvolvimento da Saúde. Universidade de São Paulo. Manual de Enfermagem. Brasília: Ministério da Saúde; 2001. p. 34-42. 
Coelho MO, Jorge MSB. Tecnologia das relações como dispositivo do atendimento humanizado na atenção básica à saúde na perspectiva do acesso, do acolhimento e do vínculo. Ciênc. Saúde Coletiva. 2009 Set-Out; 14 (1): 1523 - 31.

Coelho VAC, Fermino MAS, Tolocka RE. Atividades do cotidiano infantil em uma cidade do interior paulista e suas relações com o brincar. Licere (Online). 2012 Dez; 15 (4): 1-17.

Falkenberg MB, Mendes TPL, Moraes EP, Souza EM. Educação em saúde e educação na saúde: conceitos e implicações para a saúde coletiva. Ciênc. Saúde Coletiva. 2014 Jan-Mar; 19 (3): 847- 52.

Fernandes MCP, Backes VMS. Educação em saúde: perspectivas de uma equipe da estratégia saúde da família sob a óptica de Paulo Freire. Rev. Bras. Enferm. 2010 Jul-Ago; 63 (4): 567-73.

Figueiredo MFS, Neto JFR, Leite MTS. Educação em saúde no contexto da saúde da família na perspectiva do usuário. Interface Comunic., Saúde, Educ. 2012 Abr-Jun; 16 (41): 315-29.

Flish TMP, Alves RH, Almeida TAC, Torres HC, Schall VT, Reis DC. Como os profissionais da atenção primária percebem e desenvolvem a educação popular em saúde? Interface - Comunic., Saúde, Educ. 2014; 18 (2): 1255 - 68.

Flores O. E educação em saúde numa perspectiva transformadora. In: Brasil, Fundação Nacional da Saúde, organizadora. Educação em saúde diretrizes. Brasília: Funasa; 2007. p. 7.

Freire P. Educação e Mudança. 12ª ed. Paz e Terra, 2007.

Freire P. Pedagogia da autonomia: saberes necessários a prática educativa. 31. ed. Rio de Janeiro: Paz e Terra, 1996.

Freire P. Pedagogia do oprimido. 56 ed. Paz e Terra: Rio de Janeiro, 2014.

Hochman B, Nahas FX, Filho RSO, Ferreira LM. Desenhos de pesquisa. Acta Cirúrgica Brasileira. 2005; 20 (2).

Lacerda ABM, Soares VMN, Gonçalves CGO, Lopes FC, Testoni R. Oficinas educativas como estratégia de promoção da saúde auditiva do adolescente: estudo exploratório. ACR. 2013; 18 (2): 85-92.

Lacerda WA, Santiago IMFL. A participação popular na gestão local do programa saúde da família em Campina Grande, Paraíba. Rev. Katál. Florianópolis. 2007 Jul-Dez; 10 (2): 197-205. 
Lamy Filho F, Medeiros SM, Lamy ZC, Moreira MEL. Ambiente domiciliar e alterações do desenvolvimento em crianças de comunidade da periferia de São Luís - MA. Ciênc. Saúde Coletiva. 2011; 16 (10): 4181-87.

Lazzarotto AR, Santos VS, Reichert MT, Quevedo DM, Fossatti P, Santos GA, Calvetti PU, Sprinz E. Oficinas educativas sobre HIV/Aids: uma proposta de intervenção para idosos.Rev. Bras. Geriatr. Gerontol. 2013; 16 (4): 833-43.

Lo-Biondo-Wood G, Haber J. Pesquisa em Enfermagem: métodos, avaliação crítica e utilização. 4 ${ }^{a}$ ed. Guanabara-Koogan: Rio de Janeiro, 2001.

Martins E, Szymanski H. Brincadeira e práticas educativas familiares: um estudo com famílias de baixa renda. Interações: estudos e pesquisa em psicologia. 2006 Jan-Jun; 11 (21): 143-164.

Martins MFD, Costa JSD, Saforcada ET, Cunha MDC. Qualidade do ambiente e fatores associados: um estudo em crianças de Pelotas, Rio Grande do Sul, Brasil. Cad. Saúde Pública. 2004; 20 (3): 710-18.

Mendonça ET, Aires LFA, Amaro MO, Moreira TR, Henriques BD, Almeida LC, Castro JA, Fernandes VC, Brinati LM. A experiência de oficinas educativas com idosos: (re)pensando práticas à luz do pensamento freireano. Rev. APS. 2013 Out-Dez; 16 (4): 479-484.

Naudeau S, Kataoka N, Valerio A, Neuman MJ, Elder LK. Como investir na primeira infância: um guia para discussão de políticas e preparação de projetos de desenvolvimento da primeira infância. Tradução: Paola Morsello. Washington, DC : The World Bank, 2010; São Paulo: Singular, 2011. p. 5-10.

Oliveira JMAM, Oliveira MCM. Educação em saúde: do Campanhismo ao Saúde da Família. In: Congresso Brasileiro de História da Educação, GoiâniaGoiás. 4., 2006. Anais... Goiânia; 2006. Extraído de [http:// www.sbhe.org.br/ novo/congressos/cbhe 4/individuais-coautorais/ eixo05/ Joseane\%20Maria\%20Andrade\%20Mouzinho\% 20de\%200liveira\%20e\% 20Maria\%20Cecilia\%20M.pdf], acesso em [30 de junho de 2015].

Pedrosa JIS. Educação popular no Ministério da Saúde: identificando espaços e referências. In: Brasil. Ministério da Saúde. Secretaria de Gestão Estratégica e Participativa. Departamento de Apoio à Gestão Participativa. Caderno de educação popular e saúde/ Ministério da Saúde, Secretaria de Gestão Estratégica e 
Participativa, Departamento de Apoio à Gestão Participativa. Brasília: Ministério da Saúde, 2007.p.13-7.

Polit DF, Beck CT, Hungler BP. Fundamentos de pesquisa em enfermagem: métodos, avaliação e utilização; trad. Ana Thorell. 5 ed. Porto Alegre: Artmed, 2004.

Sá LD, Gomes ALC, Carmo JB, Souza KMJ, Palha PF, Alves RS, Andrade SLE. Educação em saúde no controle da tuberculose: perspectiva de profissionais da estratégia saúde da família. Rev. Eletr. Enf. 2010 Jan-Mar; 15 (1): 103-11.

Scalha TB, Souza VG, Boffi T. A importância do brincar no desenvolvimento psicomotor: relato de experiência. Rev. Psicol. UNESP. 2010; 9 (2): 79-92. 
APÊNDICES 


\section{APÊNDICE A - Termo de Consentimento Livre e Esclarecido (TCLE)}

Prezado familiar,

Meu nome é Danieli Teles Liviéri, sou enfermeira (Coren/SP 189405) e aluna da pós graduação da USP.

Gostaria de convidá-lo (a) a participar da minha pesquisa que busca conhecer o que as famílias sabem e fazem para promover o desenvolvimento dos seus filhos.

Caso concorde, você responderá um questionário em sua casa aplicado por uma enfermeira em dois momentos. Você poderá também participar de três reuniões em grupo com outros familiares como você na Unidade de Saúde do seu bairro, durante as quais faremos um curso sobre a brincadeira e o processo de desenvolvimento da criança.

Nessas reuniões, vozes dos participantes serão gravadas, para podermos analisar depois as informações que forem discutidas. Não haverá divulgação dos nomes dos participantes, nem das crianças.

Acredito que essa participação irá contribuir para o seu dia a dia no cuidado com seu filho, e também para melhorar as atividades educativas realizadas pelos enfermeiros.

Não haverá pagamento pela participação, nem outro tipo de benefício no serviço se você aceitar participar.

Sua participação é voluntária e, a qualquer momento, você poderá deixar de participar da pesquisa, sem que isso atrapalhe 0 atendimento de saúde que seu (sua) filho (a) recebe no serviço. Os riscos relacionados à sua participação no estudo são mínimos e referem-se ao tempo gasto para responder ao questionário e participar das atividades.

Este projeto foi submetido ao Comitê de Ética em Pesquisa da Escola de Enfermagem da USP. Você pode entrar em contato pelo 
e-mail (edipesq@usp.br) ou pelo telefone (01511 3061-7548). Este termo será assinado em duas vias, pois uma ficará com você e outra com a pesquisadora.

O senhor (senhora) gostaria de participar?

Declaro ter sido esclarecido (a) a respeito do objetivo, da forma de participação e de utilização das informações e quanto à liberdade de recusar ou interromper, a qualquer momento e sem prejuízo algum, a minha participação. Concordo em participar como informante na coleta de dados deste estudo.

Sorocaba

Assinatura do Participante:

Assinatura da Pesquisadora: 


\section{APÊNDICE B - Descrição das Atividades da Oficina Pedagógica:}

\section{"Ajudando o desenvolvimento do meu bebê"}

ENCONTRO I: "Compreendendo o desenvolvimento infantil"

\begin{tabular}{|c|c|c|c|c|}
\hline $\begin{array}{l}\text { Momento /Tempo/ } \\
\text { Materiais }\end{array}$ & Objetivo (s) & $\begin{array}{c}\text { Conteúdo } \\
\text { Programático }\end{array}$ & Técnica & Atividades \\
\hline $\begin{array}{l}\text { INTEGRAÇÃO I } \\
\text { (30 min.) } \\
\text { Materiais } \\
\text { - Flip chart. } \\
\text { - Gravador de voz }\end{array}$ & $\begin{array}{l}\text { - Conhecer os } \\
\text { participantes } \\
\text { - Facilitar a } \\
\text { integração em } \\
\text { grupo }\end{array}$ & $\begin{array}{l}\text { Apresentações } \\
\text { individuais }\end{array}$ & $\begin{array}{l}\text { Contato } \\
\text { progressivo }\end{array}$ & $\begin{array}{l}\text { 1. Acolhimento dos participantes e } \\
\text { apresentação dos objetivos da oficina. } \\
\text { Desenvolvimento } \\
\text { a) Com as cadeiras previamente dispostas em } \\
\text { círculo, os participantes são recebidos pelo } \\
\text { facilitador. } \\
\text { b) O facilitador se apresenta e introduz os } \\
\text { participantes aos objetivos. } \\
\text { c) Cada participante diz seu nome, ocupação, } \\
\text { quantos filhos têm e em qual idade. Facilitador } \\
\text { anota no Flip chart. } \\
\text { d) Os participantes são divididos em subgrupos } \\
\text { considerando a faixa etária de seus filhos para a } \\
\text { realização das atividades subsequentes. }\end{array}$ \\
\hline
\end{tabular}




\begin{tabular}{|c|c|c|c|c|}
\hline $\begin{array}{l}\text { INTEGRAÇÃO II } \\
\text { (30 min.) } \\
\text { Materiais } \\
\text { - Espaço para } \\
\text { circulação } \\
\text { participantes dos } \\
\text { - Faixas de pano para } \\
\text { vendar os olhos dos } \\
\text { participantes } \\
\text { - Gravador de voz }\end{array}$ & $\begin{array}{l}\text { Experimentar } \\
\text { e refletir sobre } \\
\text { como é "ser } \\
\text { criança", a } \\
\text { sensação de } \\
\text { dependência, } \\
\text { do cuidar e ser } \\
\text { cuidado }\end{array}$ & $\begin{array}{l}\text { Dependência da } \\
\text { criança em } \\
\text { relação ao adulto } \\
\text { Impacto do } \\
\text { cuidado sobre o } \\
\text { desenvolvimento } \\
\text { infantil (DI) } \\
\text { Relações afetivas } \\
\text { e atenciosas no } \\
\text { desenvolvimento } \\
\text { do vínculo e da } \\
\text { confiança } \\
\text { Necessidades } \\
\text { das crianças } \\
\text { explorarem } \\
\text { objetos e } \\
\text { espaços } \\
\text { (oportunidades } \\
\text { de experiências } \\
\text { fornecidas pelos } \\
\text { adultos) } \\
\text { Como as crianças } \\
\text { aprendem: de } \\
\text { maneira ativa, } \\
\text { explorando, } \\
\text { brincando, } \\
\text { imitando, } \\
\text { repetindo e se } \\
\text { relacionando. }\end{array}$ & $\begin{array}{l}\text { Dinâmica: "C } \\
\text { Cego e } \\
\text { Mudo" }\end{array}$ & $\begin{array}{l}\text { 2. Compreendendo como a criança descobre o } \\
\text { mundo a sua volta. } \\
\text { Desenvolvimento } \\
\text { a) São formadas duplas em que um é cego e o } \\
\text { outro é mudo. O mudo conduz o cego durante } 3 \\
\text { minutos para explorar o ambiente. Invertem-se as } \\
\text { posições por mais } 3 \text { minutos. } \\
\text { b) Conversam entre si sobre a experiência vivida } \\
\text { durante outros } 3 \text { minutos. } \\
\text { c) Finalização no grupo geral com relatos das } \\
\text { duplas e reflexões do facilitador. }\end{array}$ \\
\hline
\end{tabular}




\begin{tabular}{|c|c|c|c|c|}
\hline \multicolumn{5}{|l|}{ INTERVALO - Café } \\
\hline $\begin{array}{l}\text { O QUE É O } \\
\text { DESENVOLVMENTO } \\
\text { INFANTIL (DI) E } \\
\text { COMO OCORRE? } \\
\text { (1 hora) } \\
\text { Materiais } \\
\text { - Caderneta de Saúde } \\
\text { da Criança } \\
\text { - Flip chart } \\
\text { - Computador e Data } \\
\text { show } \\
\text { - Vídeos: } \\
\text { "Jogo de ação e } \\
\text { reação modela os } \\
\text { circuitos do cérebro" - } \\
\text { NCPI - Núcleo Ciência } \\
\text { pela Infância. } \\
\text { "Como é o } \\
\text { desenvolvimento do } \\
\text { bebê" - Johnson's. } \\
\text { - Gravador de voz }\end{array}$ & $\begin{array}{l}\text { - Refletir e } \\
\text { estimular o } \\
\text { interesse } \\
\text { sobre o } \\
\text { processo do DI } \\
\text { - Favorecer a } \\
\text { troca de } \\
\text { experiências } \\
\text { entre os } \\
\text { participantes } \\
\text { - Promover a } \\
\text { compreensão } \\
\text { sobre o } \\
\text { processo do DI }\end{array}$ & $\begin{array}{l}\text { DI e suas } \\
\text { peculiaridades } \\
\text { em cada faixa } \\
\text { etária } \\
\text { Influência do } \\
\text { contexto no DI } \\
\text { Estimulação do } \\
\text { DI } \\
\text { Comportamentos } \\
\text { exploratórios da } \\
\text { criança, } \\
\text { consciência do } \\
\text { próprio corpo, } \\
\text { "birra", imitação } \\
\text { (caretas, sorrisos, } \\
\text { barulhos), } \\
\text { desenvolvimento } \\
\text { da autonomia, } \\
\text { necessidade de } \\
\text { repetição e de } \\
\text { rotina. }\end{array}$ & $\begin{array}{l}\text { - Discussão em } \\
\text { subgrupo } \\
\text { - Exposição } \\
\text { dialogada } \\
\text { - Vídeo }\end{array}$ & $\begin{array}{l}\text { 3. Compreendendo o desenvolvimento infantil. } \\
\text { Desenvolvimento } \\
\text { a) No subgrupo, discutem o que consideram ser o } \\
\text { desenvolvimento infantil e como percebem este } \\
\text { acontecendo em seus filhos. São orientados a } \\
\text { explorarem a "Caderneta de Saúde da Criança", } \\
\text { especificamente no conteúdo de "Estimulando o } \\
\text { desenvolvimento da criança com afeto". } \\
\text { b) Apresentação geral no grupo e discussão dos } \\
\text { pontos levantados. } \\
\text { c) Os participantes assistem aos vídeos. } \\
\text { d) Síntese geral conduzida pelo facilitador } \\
\text { correlacionando os conteúdos do vídeo e da } \\
\text { "Caderneta de Saúde da Criança", com as } \\
\text { experiências apresentadas pelos participantes. }\end{array}$ \\
\hline
\end{tabular}


Encontro II: "Promovendo o desenvolvimento infantil por meio do brincar"

\begin{tabular}{|c|c|c|c|c|}
\hline $\begin{array}{c}\text { Momento /tempo/ } \\
\text { materiais }\end{array}$ & Objetivo (s) & $\begin{array}{c}\text { Conteúdo } \\
\text { Programático }\end{array}$ & Técnica & Atividades \\
\hline $\begin{array}{l}\text { A INFÂNCIA E O } \\
\text { BRINCAR } \\
\text { (2 horas) } \\
\text { Materiais } \\
\text { - Folhas de papel } \\
\text { - Canetas e lápis } \\
\text { - Flip chart } \\
\text { - Caderneta de Saúde } \\
\text { da Criança }\end{array}$ & $\begin{array}{l}\text { - Sensibilizar os } \\
\text { familiares sobre } \\
\text { a importância do } \\
\text { brincar com } \\
\text { seus filhos }\end{array}$ & $\begin{array}{l}\text { Relembrar as } \\
\text { brincadeiras } \\
\text { preferidas na } \\
\text { infância e os } \\
\text { momentos em } \\
\text { que brincavam } \\
\text { com seus pais }\end{array}$ & $\begin{array}{l}\text { - Indicação de uma } \\
\text { brincadeira por cada } \\
\text { um } \\
\text { - Indicação de um } \\
\text { sentimento durante o } \\
\text { momento de brincar } \\
\text { com seus pais } \\
\text { - Exposição do } \\
\text { conteúdo exposto em } \\
\text { um painel }\end{array}$ & $\begin{array}{l}\text { 1. Reconectando-se com a própria infância } \\
\text { Desenvolvimento } \\
\text { a) Neste momento, as seguintes questões } \\
\text { conduzem a atividade: } \\
\text { - Quando eram pequenos, em que } \\
\text { espaços vocês brincavam? } \\
\text { Quais eram as suas brincadeiras } \\
\text { preferidas nessa época? } \\
\text { - Vocês tinham algum brinquedo } \\
\text { favorito? } \\
\text { - Esses momentos de brincadeiras na } \\
\text { infância tiveram algum significado para } \\
\text { a sua vida adulta? } \\
\text { b) Cada participante escolhe e escreve na } \\
\text { folha de papel a brincadeira que mais gostava } \\
\text { na infância e indica um sentimento que } \\
\text { permeava esses momentos, relembrando o } \\
\text { brincar com seus pais. } \\
\text { c) Cada participante expõe para o grupo as } \\
\text { suas indicações. } \\
\text { d) Em seguida, o facilitador reúne os materiais } \\
\text { produzidos e cola em um cartaz, que ficará } \\
\text { exposto durante todo encontro. }\end{array}$ \\
\hline
\end{tabular}




\begin{tabular}{|c|c|c|c|c|}
\hline \multicolumn{5}{|l|}{ INTERVALO - Café } \\
\hline & $\begin{array}{l}\text { - Desenvolver } \\
\text { estratégias de } \\
\text { promoção do } \\
\text { desenvolviment } \\
\text { o através do } \\
\text { brincar } \\
\text { - Estimular a } \\
\text { incorporação da } \\
\text { brincadeira nos } \\
\text { cuidados } \\
\text { familiares }\end{array}$ & $\begin{array}{l}\text { Importância da } \\
\text { ludicidade e do } \\
\text { respeito ao } \\
\text { direito de } \\
\text { brincar } \\
\text { A brincadeira } \\
\text { em cada estágio } \\
\text { do DI } \\
\text { O brincar entre } \\
\text { a criança e o } \\
\text { adulto }\end{array}$ & $\begin{array}{l}\text { - Discussão em } \\
\text { subgrupo } \\
\text { - Discussão no grupo } \\
\text { geral }\end{array}$ & $\begin{array}{l}\text { 2. Promovendo o DI por meio do brincar } \\
\text { Desenvolvimento } \\
\text { a) Cada subgrupo indica estratégias utilizando } \\
\text { o brincar para promover o desenvolvimento da } \\
\text { criança, considerando o contexto em que } \\
\text { vivem. São estimulados a explorarem a } \\
\text { "Caderneta de Saúde da Criança". As } \\
\text { seguintes questões conduzem a atividade: } \\
\text { - Você brinca com o seu filho? Como e } \\
\text { quando? } \\
\text { - Quais brincadeiras você considera } \\
\text { importantes para a idade dele? } \\
\text { - É necessário sempre ter algum } \\
\text { brinquedo para que a brincadeira } \\
\text { aconteça? } \\
\text { - Pensando na sua casa e nos recursos } \\
\text { disponíveis nela, como você pode criar } \\
\text { brincadeiras? } \\
\text { c) Discussão das estratégias no grupo geral. }\end{array}$ \\
\hline $\begin{array}{lr}\text { A EXPERIÉNCIA } & \text { EM } \\
\text { PARTICIPAR } & \text { DA } \\
\text { OFICINA } & \\
\text { PEDAGÓGICA } & \text { COM } \\
\text { FOCO } & \text { NA } \\
\text { PROMOÇÃO DO DI }\end{array}$ & $\begin{array}{l}\text { - } \text { Discutir sobre } \\
\text { a participação } \\
\text { na Oficina } \\
\text { Pedagógica } \\
\text { - Avaliar a } \\
\text { Oficina } \\
\text { Pedagógica }\end{array}$ & & $\begin{array}{l}\text { Discussão no grupo } \\
\text { geral } \\
\text { Aplicação do } \\
\text { questionário de } \\
\text { avaliação }\end{array}$ & $\begin{array}{l}\text { 1. Avaliando a Oficina Pedagógica } \\
\text { Desenvolvimento } \\
\text { a) A discussão será conduzida pela questão } \\
\text { norteadora: "Como foi participar de um } \\
\text { encontro que falasse sobre o } \\
\text { desenvolvimento da criança?" }\end{array}$ \\
\hline
\end{tabular}




\begin{tabular}{|l|l|l|l|}
\hline $\begin{array}{l}\text { Materiais } \\
-\quad \text { Instrumento de }\end{array}$ & & $\begin{array}{l}\text { b) Cada participante relata a experiência de ter } \\
\text { participado da Oficina Pedagógica. } \\
\text { avaliação } \\
- \text { Gravador de voz }\end{array}$ & $\begin{array}{l}\text { Cada participante preencherá um } \\
\text { questionário de avaliação da Oficina } \\
\text { Pedagógica. }\end{array}$ \\
\hline ENCERRAMENTO &
\end{tabular}


APÊNDICE C - Questionário de Avaliação da Oficina Pedagógica

Idade da mãe:

Escolaridade da mãe:

Idade do bebê:

Gostaria de saber sua opinião sobre a Oficina. Por favor, assinale a alternativa conforme o seu desejo.

1 AVALIAÇÃO GERAL (De forma geral, como você avalia a Oficina?)
A- Ótimo
B- Bom
C- Razoável
D- Ruim

Comentários:

2 CONTEÚDO DO CURSO (Qual sua opinião especificamente sobre os assuntos e temas abordados no curso?).
A- Ótimo
B- Bom
C- Razoável
D- Ruim

Comentários:

3 FORMA DE APRESENTAÇÃO DO CURSO (Qual sua opinião sobre a forma como as discussões aconteceram?)
A- Ótimo
B- Bom
C- Razoável
D- Ruim

Comentários: 
4 APLICABILIDADE (Você será capaz de fazer o que aprendeu em seu dia a dia?)

A- sim

B- não

C- mais ou menos

Comentários:

5 CARGA HORÁRIA (O tempo do curso foi suficiente?)

A- foi o necessário

B- foi muito

C- foi pouco

Comentários:

6 VOCÊ JÁ TINHA PARTICIPADO DE ALGUMA OUTRA ATIVIDADE COM ESSE MESMO TEMA?
A- $\operatorname{Sim}$
B- Não

7 VOCÊ JÁ TINHA RECEBIDO ORIENTAÇÕES SOBRE COMO ESTIMULAR O DESENVOLVIMENTO DO SEU BEBÊ?
A- $\operatorname{Sim}$
B- Não

8 VOCÊ LÊ OU JÁ LEU OS CONTEÚDOS DA CADERNETA DE SAÚDE DA CRIANÇA ("CARTEIRINHA DE VACINA")
A- $\operatorname{Sim}$
B- Não

Por favor, se quiser fazer mais algum comentário, críticas ou sugestões, escreva no espaço abaixo. Sua opinião é muito importante. OBRIGADA! 
ANEXOS 


\section{ANEXO 1 - FOLHA DE REGISTRO - HOME - 0-3 ANOS}

Data de entrevista

Relação da Pessoa entrevistada com a pessoa:

Local da entrevista:

Pessoas presentes no momento da entrevista:

Comentários:

\begin{tabular}{|l|l|}
\hline \multicolumn{1}{|c|}{ FATORES } & ESCORES BRUTOS \\
\hline I. Responsividade emocional e verbal da mãe & \\
\hline II. Ausência de punição e restrição & \\
\hline III. Organização do ambiente físico e temporal & \\
\hline $\begin{array}{l}\text { IV. Disponibilidade de materiais, brinquedos e } \\
\text { jogos apropriados }\end{array}$ & \\
\hline $\begin{array}{l}\text { V. Envolvimento materno com a criança } \\
\text { VI. Oportunidade de variação na estimulação } \\
\text { diária }\end{array}$ & \\
\hline \multicolumn{1}{|c|}{ TOTAL } & \\
\hline
\end{tabular}

\begin{tabular}{|l|c|c|}
\hline I- RESPONSIVIDADE EMOCIONAL E VERBAL DA MÃE & SIM & NÃO \\
\hline $\begin{array}{l}\text { 1. A mãe vocaliza espontaneamente em relação à criança } \\
\text { pelo menos duas vezes durante a visita (exclui-se chamar } \\
\text { a atenção ou passar pito). }\end{array}$ & 1 & 0 \\
\hline $\begin{array}{l}\text { 2. A mãe responde às vocalizações da criança com uma } \\
\text { resposta vocal ou verbal. }\end{array}$ & 1 & 0 \\
\hline $\begin{array}{l}\text { 3. A mãe diz à criança o nome de algum objeto durante a } \\
\text { visita ou diz o nome de uma pessoa ou objeto num estilo } \\
\text { "didático". }\end{array}$ & 1 & 0 \\
\hline $\begin{array}{l}\text { 4. A fala da mãe é distinta, clara e audível para o } \\
\text { entrevistador-observador. }\end{array}$ & 1 & 0 \\
\hline 5. A mãe inicia intercâmbio verbal com o observador - faz & 1 & 0 \\
\hline
\end{tabular}




\begin{tabular}{|l|c|c|}
\hline perguntas e comentários espontâneos. & & 0 \\
\hline $\begin{array}{l}\text { 6. A mãe expressa ideias livres e facilmente, e usa frases } \\
\text { de tamanho adequado para conversar (por exemplo, } \\
\text { apresenta mais do que meras e breves respostas). }\end{array}$ & 1 & 0 \\
\hline $\begin{array}{l}\text { 7. A mãe permite à criança ocasionalmente envolver-se } \\
\text { em jogos e brincadeiras que sujam o ambiente ou a } \\
\text { própria criança. }\end{array}$ & 1 & 0 \\
\hline $\begin{array}{l}\text { 8. A mãe espontaneamente elogia as qualidades ou } \\
\text { comportamentos da criança pelo menos duas vezes } \\
\text { durante a visita. }\end{array}$ & 1 & 0 \\
\hline $\begin{array}{l}\text { 9. Quando falando sobre ou para a criança a voz da mãe } \\
\text { transmite um sentimento positivo. }\end{array}$ & 1 & 0 \\
\hline $\begin{array}{l}\text { 10. A mãe acaricia ou beija a criança pelo menos uma vez } \\
\text { durante a visita. }\end{array}$ & 1 & 0 \\
\hline $\begin{array}{l}\text { 11. A mãe mostra alguma resposta emocional positiva } \\
\text { frente a elogios feitos a criança pelo observador. }\end{array}$ & 1 & \\
\hline \multicolumn{1}{|c|}{ SUBCORE } & \\
\hline
\end{tabular}

\begin{tabular}{|c|c|c|}
\hline II - AUSÊNCIA DE RESTRIÇÃO E PUNIÇÃO & SIM & NÃO \\
\hline 12. A mãe não grita com a criança durante a visita. & 1 & 0 \\
\hline $\begin{array}{l}\text { 13. A mãe não expressa irritação, aborrecimento ou } \\
\text { hostilidade aberta em relação à criança. }\end{array}$ & 1 & 0 \\
\hline 14. A mãe não esbofeteia a criança durante a visita. & 1 & 0 \\
\hline $\begin{array}{l}\text { 15. A mãe relata apenas uma ocorrência de punição física } \\
\text { que tenha ocorrido durante a semana passada. }\end{array}$ & 1 & 0 \\
\hline $\begin{array}{l}\text { 16. A mãe não critica, passa "pito" ou "arrasa" } \\
\text { verbalmente com a criança durante a visita. }\end{array}$ & 1 & 0 \\
\hline $\begin{array}{l}\text { 17. A mãe não interfere com as ações da criança ou } \\
\text { restringe seus movimentos mais do que } 3 \text { vezes durante a } \\
\text { visita. }\end{array}$ & 1 & 0 \\
\hline 18. Pelo menos 10 livros estão presentes e visíveis no lar. & 1 & 0 \\
\hline 19. A família tem um animal de estimação. & 1 & 0 \\
\hline \multicolumn{3}{|l|}{ SUB-ESCORE } \\
\hline III - ORGANIZAÇÃO DO AMBIENTE FÍSICO E TEMPORAL & SIM & NÃO \\
\hline $\begin{array}{l}\text { 20. Quando a mãe se ausentava, o cuidado à criança é } \\
\text { fornecido por pelo menos uma de três substitutas } \\
\text { regulares. }\end{array}$ & 1 & 0 \\
\hline $\begin{array}{l}\text { 21. Alguém leva a criança à quitanda, supermercado, etc., } \\
\text { pelo menos uma vez por semana. }\end{array}$ & 1 & 0 \\
\hline $\begin{array}{l}\text { 22. A criança sai de casa pelo menos quatro vezes por } \\
\text { semana. }\end{array}$ & 1 & 0 \\
\hline
\end{tabular}




\begin{tabular}{|c|c|c|}
\hline $\begin{array}{l}\text { 23. A criança é levada regularmente ao médico ou clínica } \\
\text { para verificação de saúde ou cuidados preventivos. }\end{array}$ & 1 & 0 \\
\hline $\begin{array}{l}\text { 24. A criança tem um lugar especial no qual pode guardar } \\
\text { seus brinquedos e pequenos "tesouros". }\end{array}$ & 1 & 0 \\
\hline $\begin{array}{l}\text { 25. O ambiente de brinquedos, de jogos da criança parece } \\
\text { seguro e livre de acidentes. }\end{array}$ & 1 & 0 \\
\hline \multicolumn{3}{|l|}{ SUB-ESCORE } \\
\hline $\begin{array}{l}\text { IV - DISPONIBILIDADE DE MATERIAIS DE BRINQUEDOS E } \\
\text { JOGOS APROPRIADOS }\end{array}$ & SIM & NÃO \\
\hline $\begin{array}{l}\text { 26. A criança tem brinquedos ou outros objetos que } \\
\text { envolvam atividade muscular. }\end{array}$ & 1 & 0 \\
\hline 27. A criança tem brinquedos de empurrar ou puxar. & 1 & 0 \\
\hline $\begin{array}{l}\text { 28. A criança tem uma patinete, um andador, um triciclo, } \\
\text { qualquer carrinho que a criança impulsiona com os pés. }\end{array}$ & 1 & 0 \\
\hline $\begin{array}{l}\text { 29. A mãe fornece brinquedos ou sugere atividades } \\
\text { interessantes para a criança durante a visita. }\end{array}$ & 1 & 0 \\
\hline $\begin{array}{l}\text { 30. A mãe fornece objetos apropriados para a } \\
\text { aprendizagem de acordo com a idade da criança: } \\
\text { brinquedos de pelúcia ou jogos de faz de conta. }\end{array}$ & 1 & 0 \\
\hline $\begin{array}{l}\text { 31. A mãe fornece material de aprendizagem apropriado à } \\
\text { idade da criança: móbiles, mesas e cadeiras, cadeirões, } \\
\text { chiqueirinho. }\end{array}$ & 1 & 0 \\
\hline $\begin{array}{l}\text { 32. A mãe fornece brinquedos que favorecem a } \\
\text { coordenação viso-motora - por exemplo: peças para } \\
\text { serem introduzidas ou retirada de orifícios, caixas, contas } \\
\text { para enfiar, etc. }\end{array}$ & 1 & 0 \\
\hline $\begin{array}{l}\text { 33. A mãe fornece brinquedos que favorecem a } \\
\text { coordenação viso-motora e que permitam combinações: } \\
\text { jogos de empilhar ou encaixar blocos, etc. }\end{array}$ & 1 & 0 \\
\hline $\begin{array}{l}\text { 34. A mãe fornece brinquedos que estimulem a leitura e a } \\
\text { música. }\end{array}$ & 1 & 0 \\
\hline \multicolumn{3}{|l|}{ SUB-ESCORE } \\
\hline V - ENVOLVIMENTO MATERNOS COM A CRIANÇA & SIM & NÃO \\
\hline $\begin{array}{l}\text { 35. A mãe tende a conservar a criança dentro do seu } \\
\text { campo visual e tende a olha-la frequentemente. }\end{array}$ & 1 & 0 \\
\hline $\begin{array}{l}\text { 36. A mãe fala à criança enquanto realiza seu trabalho de } \\
\text { casa. }\end{array}$ & 1 & 0 \\
\hline $\begin{array}{l}\text { 37. A mãe conscientemente encoraja o desenvolvimento } \\
\text { da criança. }\end{array}$ & 1 & 0 \\
\hline $\begin{array}{l}\text { 38. A mãe investe em brinquedos mais complexos através } \\
\text { de sua atenção. }\end{array}$ & 1 & 0 \\
\hline 39. A mãe estrutura os períodos de brinquedo da c & 1 & 0 \\
\hline
\end{tabular}




\begin{tabular}{|l|c|c|}
\hline $\begin{array}{l}\text { 40. A mãe fornece brinquedos que desafiam a criança a } \\
\text { desenvolver novas habilidades. }\end{array}$ & 1 & 0 \\
\hline \multicolumn{1}{|c|}{ SUB-ESCORE } & & \\
\hline $\begin{array}{l}\text { VI - OPORTUNIDADE DE VARIAÇÃO NA ESTIMULAÇÃO } \\
\text { DIÁRIA }\end{array}$ & SIM & NÃO \\
\hline $\begin{array}{l}\text { 41. O pai fornece algum cuidado à criança a cada dia. } \\
\text { por. A mãe lê histórias para a criança pelo menos 3 vezes }\end{array}$ & 1 & 0 \\
\hline $\begin{array}{l}\text { 43. A criança come pelo menos uma refeição por dia com a } \\
\text { mãe e o pai. }\end{array}$ & 1 & 0 \\
\hline 44. A família visita ou recebe visitas de parentes. & 1 & 0 \\
\hline 45. A criança possui três ou mais livros. & 1 & 0 \\
\hline \multicolumn{1}{|c|}{ SUB-ESCORE } & & \\
\hline
\end{tabular}




\section{ANEXO 2 - CRITÉRIO DE CLASSIFICAÇÃO ECONÔMICA BRASIL}

\section{Modelo de Questionário sugerido para aplicação}

P.XX Agora vou fazer algumas perguntas sobre itens do domicilio para efeito de classificação econômica. Todos os itens de eletroeletrônicos que vou citar devem estar funcionando, incluindo os que estão guardados. Caso não estejam funcionando, considere apenas se tiver intenção de consertar ou repor nos próximos seis meses.

INSTRUÇÃO: Todos os itens devem ser perguntados pelo entrevistador e respondidos pelo entrevistado.

Vamos começar? No domicílio tem (LEIA CADA ITEM)

\begin{tabular}{|c|c|c|c|c|c|}
\hline & \multicolumn{4}{|c|}{$\begin{array}{l}\text { QUANTIDADE QUE POSSUI } \\
\end{array}$} \\
\hline ITENS DE CONFORTO & \begin{tabular}{|c|} 
NÃOO \\
POSSUI \\
\end{tabular} & 1 & 2 & 3 & $4+$ \\
\hline \multicolumn{6}{|l|}{$\begin{array}{l}\text { Quantidade de automóveis de passeio exclusivamente para uso } \\
\text { particular }\end{array}$} \\
\hline \multicolumn{6}{|l|}{$\begin{array}{l}\text { Quantidade de empregados mensalistas, considerando apenas os } \\
\text { que trabalham pelo menos cinco dias por semana }\end{array}$} \\
\hline \multicolumn{6}{|l|}{ Quantidade de máquinas de lavar roupa, excluindo tanquinho } \\
\hline \multicolumn{6}{|l|}{ Quantidade de banheiros } \\
\hline \multicolumn{6}{|l|}{$\begin{array}{l}\text { DVD, incluindo qualquer dispositivo que leia DVD e desconsiderando } \\
\text { DVD de automóvel }\end{array}$} \\
\hline \multicolumn{6}{|l|}{ Quantidade de geladeiras } \\
\hline \multicolumn{6}{|l|}{ Quantidade de freezers independentes ou parte da geladeira duplex } \\
\hline \multicolumn{6}{|l|}{ Quantidade de microcomputadores, considerando computadores de } \\
\hline \multicolumn{6}{|l|}{$\begin{array}{l}\text { mesa, laptops, notebooks e netbooks e desconsiderando tablets, } \\
\text { palms ou smartphones }\end{array}$} \\
\hline \multicolumn{6}{|l|}{ Quantidade de lavadora de louças } \\
\hline \multicolumn{6}{|l|}{ Quantidade de fornos de micro-ondas } \\
\hline \multicolumn{6}{|l|}{$\begin{array}{l}\text { Quantidade de motocicletas, desconsiderando as usadas } \\
\text { exclusivamente para uso profissional }\end{array}$} \\
\hline $\begin{array}{l}\text { Quantidade de máquinas secadoras de roupas, considerando lava e } \\
\text { seca }\end{array}$ & & & & & \\
\hline
\end{tabular}


A água utilizada neste domicílio é proveniente de?

\begin{tabular}{|l|l|}
\hline 1 & Rede geral de distribuição \\
\hline 2 & Poço ou nascente \\
\hline 3 & Outro meio \\
\hline
\end{tabular}

Considerando o trecho da rua do seu domićlio, você diria que a rua é:

\begin{tabular}{|l|l|}
\hline 1 & Asfaltada/Pavimentada \\
\hline 2 & Terra/Cascalho \\
\hline
\end{tabular}

Qual é o grau de instrução do chefe da família? Considere como chefe da família a pessoa que contribui com a maior parte da renda do domicílio.

\begin{tabular}{|l|l|}
\hline \multicolumn{1}{|c|}{ Nomenclatura atual } & \multicolumn{1}{c|}{ Nomenclatura anterior } \\
\hline Analfabeto / Fundamental I incompleto & Analfabeto/Primário Incompleto \\
\hline $\begin{array}{l}\text { Fundamental I completo / Fundamental II } \\
\text { incompleto }\end{array}$ & $\begin{array}{l}\text { Primário Completo/Ginásio } \\
\text { Incompleto }\end{array}$ \\
\hline $\begin{array}{l}\text { Fundamental completo/Médio } \\
\text { incompleto }\end{array}$ & $\begin{array}{l}\text { Ginásio Completo/Colegial } \\
\text { Incompleto }\end{array}$ \\
\hline Médio completo/Superior incompleto & $\begin{array}{l}\text { Colegial Completo/Superior } \\
\text { Incompleto }\end{array}$ \\
\hline Superior completo & Superior Completo \\
\hline
\end{tabular}

\section{SISTEMA DE PONTOS}

\section{Variáveis}

\begin{tabular}{|l|l|l|l|l|l|}
\hline & \multicolumn{7}{c}{ Quantidade } & \multicolumn{1}{c|}{} \\
\hline & $\mathbf{0}$ & $\mathbf{1}$ & $\mathbf{2}$ & $\mathbf{3}$ & $\mathbf{4}$ ou + \\
\hline Banheiros & 0 & 3 & 7 & 10 & 14 \\
\hline Empregados domésticos & 0 & 3 & 7 & 10 & 13 \\
\hline Automóveis & 0 & 3 & 5 & 8 & 11 \\
\hline Microcomputador & 0 & 3 & 6 & 8 & 11 \\
\hline Lava louca & 0 & 3 & 6 & 6 & 6 \\
\hline Geladeira & 0 & 2 & 3 & 5 & 5 \\
\hline Freezer & 0 & 2 & 4 & 6 & 6 \\
\hline Lava roupa & 0 & 2 & 4 & 6 & 6 \\
\hline DVD & 0 & 1 & 3 & 4 & 6 \\
\hline Micro-ondas & 0 & 2 & 4 & 4 & 4 \\
\hline Motocicleta & 0 & 1 & 3 & 3 & 3 \\
\hline Secadora roupa & 0 & 2 & 2 & 2 & 2 \\
\hline
\end{tabular}


Grau de instrução do chefe de família e acesso a serviços públicos

\begin{tabular}{|c|c|}
\hline \multicolumn{2}{|l|}{ Escolaridade da pessoa de referência } \\
\hline Analfabeto / Fundamental I incompleto & 0 \\
\hline Fundamental I completo / Fundamental II incompleto & 1 \\
\hline Fundamental II completo / Médio incompleto & 2 \\
\hline Médio completo / Superior incompleto & 4 \\
\hline Superior completo & 7 \\
\hline \multicolumn{2}{|l|}{ Serviços públicos } \\
\hline Não & Sim \\
\hline Água encanada & 4 \\
\hline Rua pavimentada & 2 \\
\hline
\end{tabular}

\section{Cortes do Critério Brasil}

\begin{tabular}{|cc|}
\hline Classe & Pontos \\
\hline A & $45-100$ \\
\hline B1 & $38-44$ \\
\hline B2 & $29-37$ \\
\hline C1 & $23-28$ \\
\hline C2 & $17-22$ \\
\hline D - E & $0-16$ \\
\hline
\end{tabular}




\section{ANEXO 3 - APROVAÇÃO COMITÊ DE ÉTICA EM PESQUISA DA EEUSP}

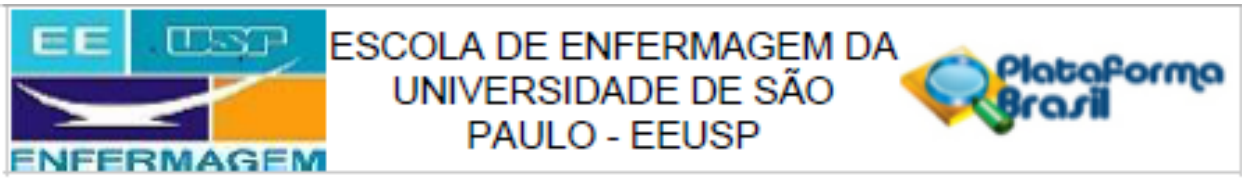

\section{PARECER CONSUBSTANCIADO DO CEP}

\section{DADOS DO PROJETO DE PESQUISA}

Título da Pesquisa: Práticas familiares: estratégia educativa para promoção do desenvolvimento infantil

Pesquisador: Danieli Teles Liviéri

Area Temática:

Versão: 2

CAAE: 38202814.2 .0000 .5392

Instituição Proponente: Escola de Enfermagem da Universidade de São Paulo - EEUSP

Patrocinador Principal: Financiamento Próprio

\section{DADOS DO PARECER}

Número do Parecer: 852.230

Data da Relatoria: $08 / 02 / 2015$

Apresentação do Projeto:

Estudo de caso-controle, para teste de uma atividade educativa, com abordagens qualitativa e quantitativa.A amostra será composta por familiares de lactentes frequentadores da Unidade de Puericultura Miltes Saraiva da Silva em Boituva/SP. Os participantes serão divididos entre grupo intervenção (GI) e grupo controle (GC). O GI participará de uma atividade educativa sobre o processo de desenvolvimento infantil e sua promoção através do brincar. A composiçăo deste grupo será por aqueles que, espontaneamente, se disponham a participar da oficina educativa. O GC será definido buscando a homogeneidade da amostra entre os dois grupos: Gl e GC.

A hipótese principal é que a atividade educativa auxilia na construção de conhecimento das familias e na incorporaçăo de práticas de cuidado relacionado ao brincar. A intervenção proposta é uma atividade educativa para familiares de lactentes sobre o processo de desenvolvimento infantil e sua promoçäo através do brincar. Estes participarão de uma oficina educativa envolvendo os seguintes temas gerais "Compreendendo o desenvolvimento infanti" e "Promovendo o desenvolvimento infantil através do brincar". Os participantes serão divididos em grupo intervenção (Gl) e grupo controle (GC). O Gl será composto por aqueles que, espontaneamente, se disponham a participar das oficinas educativas. Serão convidados todos os familiares que comparecerem à unidade para atendimento de saúde da criança no período de um mês. 0 número

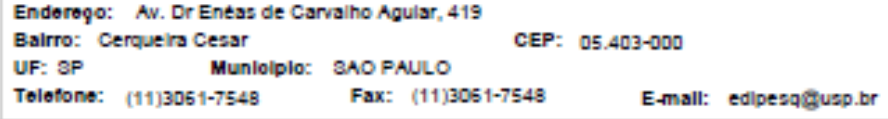




\section{EE एव्यु ESCOLA DE ENFERMAGEM DA UNIVERSIDADE DE SÃO Q Platoforma FNFFRMAGFM PAULO - EEUSP}

Continuegsto do Parecor. 962230

mínimo de participantes no $\mathrm{GI}$ deverá ser igual a 6 e o máximo igual a $15.0 \mathrm{GC}$ será definido buscando a homogeneidade da amostra entre os dois grupos, com critérios de pareamento bem definidos. Antes do inicio da oficina, será aplicado o inventário Home Observation for Measurement of the Environment Scale (HOME) para mensurar a estimulaçäo no ambiente familiar por parte do cuidador da criança a todos os participantes. Será utilizada a versăo do instrumento para o grupo etário entre 0 a 3 anos de idade. Para a oficina, seräo programados três encontros, conduzidos pela própria pesquisadora, com intervalo de um més e duraçäo de cerca de uma hora.

Estão previstas análises quantitativa e qualitativa (Análise de Conteúdo descrita por Bardin-2009).

Objetivo da Pesquisa:

Objetivo Primário:

Avaliar o efeito de uma atividade educativa sobre os conhecimentos e práticas dos familiares de lactentes relativos à promoçâo do desenvolvimento infantil através do brincar.

Objetivo Secundário:

Promover a compreensăo dos familiares sobre a brincadeira e o processo de desenvolvimento da criança. Estimular a incorporaçäo da brincadeira nos cuidados familiares à criança.

\section{Avaliação dos Riscos e Beneficios:}

Riscos: Minimo.

Beneficios: Contribuir para a melhoria das práticas familiares de cuidado à criança com foco na promoção do desenvolvimento infantil através do brincar,garantindo assim, o desenvolvimento pleno da criança.

Comentários e Considerações sobre a Pesquisa:

Trata-se de estudo que propöe realizar oficinas educativas, em dois grupos bem definidos de participantes, convidados entre os familiares de lactentes frequentadores de uma unidade de puericultura localizada em Boituva-SP. O método é bem apresentado e os instrumentos apresentados (Entrevista inventário HOME e questionário de avaliação da oficina).

Foram solicitadas adequaçöes ao termo de consentimento livre e esclarecido, que foi modificado e encontrase apropriado aos fins a que se destina.

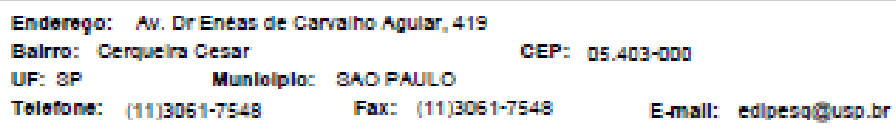




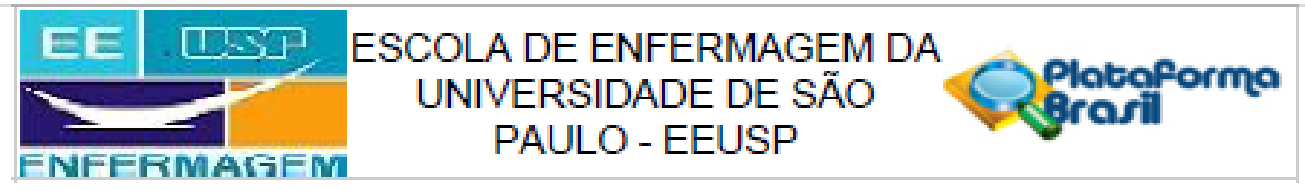

Continuesso do Parecer. 962230

Considerações sobre os Termos de apresentação obrigatória:

Foram providenciadas as adequações solicitadas e os pesquisadores apresentaram termos para o grupo intervenção e grupo controle. meios de contato local foram incluídos no termo.

Recomendações:

Sem recomendaçöes

Conclusões ou Pendências e Lista de Inadequações:

Aprovado

Situaçäo do Parecer:

Aprovado

Necessita Apreciação da CONEP:

Nä่

Considerações Finais a critério do CEP:

A aprovação do Comitê de Ética em Pesquisa da EEUSP não substitui a autorização da instituiçăo coparticipante para o inicio da pesquisa.

O CEP EEUSP informa que há necessidade de registro dos relatórios: parcial e final da pesquisa, na Plataforma Brasil.

SAO PAULO, 11 de Fevereiro de 2015

Assinado por:

Ruth Natalia Teresa Turrini

(Coordenador)

Enderego: Av. Dr Entas de Carvalho Agular, 419
Balrro: Cerqueira Cesar
$\begin{array}{llll}\text { UF: SP } & \text { Munlolplo: BAO PAULO } & \text { CEP: } 05.403-000 \\ \text { Tolotone: (11)3051-7548 } & \text { Fax: (11)3061-7548 } & \text { E-mall: edlpesqgusp.br }\end{array}$




\title{
ANEXO 4 - APROVAÇÃO DA SECRETARIA DE SAÚDE DO MUNICÍPIO DA SOROCABA/SP
}

\author{
Prefeitura de \\ SOROCABA \\ Secretaria da Saúde \\ CARTA DE AUTORIZAÇÃO PARA O DESENVOLVIMENTO DE PESQUISAS NAS \\ UNIDADES SOB RESPONSABILIDADE DA SECRETARIA DA SAÚDE DE \\ SOROCABA

\begin{abstract}
A Área de Educação em Saúde da Secretaria da Saúde de Sorocaba, declara estar informada a respeito do desenvolvimento da pesquisa intitulada " Conhecimento e práticas familiares para a promoção do desenvolvimento inf̧antil: proposta de estratégia educativa", sob responsabilidade da pesquisadora Danieli Teles Livieri. Ciente de que a mesma será conduzida conforme os princípios éticos em pesquisa vigentes no país, essa Instituição afirma ter condições para o desenvolvimento deste projeto e autoriza a execução.
\end{abstract}

Atenciosamente,

Sorocaba, 11 de Março de 2015.

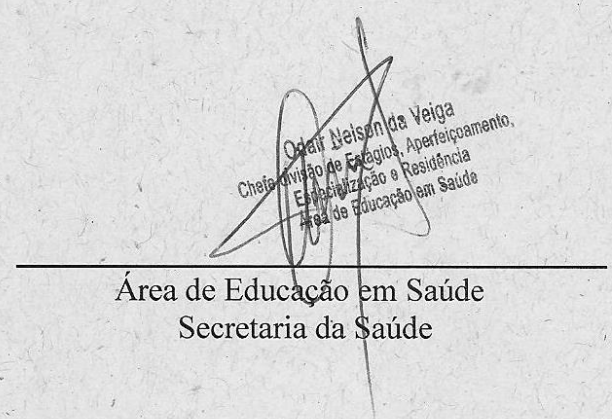

